\title{
Discovery of small-molecule inhibitors of Uba1 and development of step-specific assays for PCNA ubiquitination
}

\author{
Ph.D. Thesis \\ Paras Gaur \\ Supervisor: Lajos Haracska, Ph.D, D.Sc. \\ Doctoral School of Biology \\ University of Szeged \\ Institute of Genetics \\ Biological Research Centre, Szeged
}

Szeged, 2020 


\section{Table of Contents}

List of Abbreviations

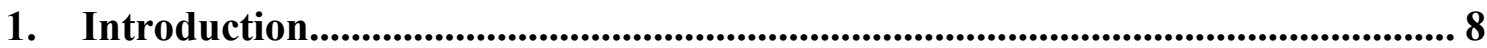

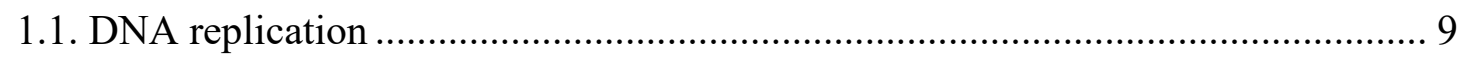

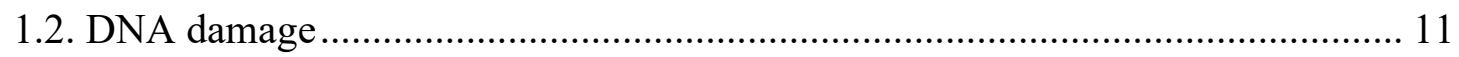

1.3. DNA damage tolerance/bypass ................................................................. 11

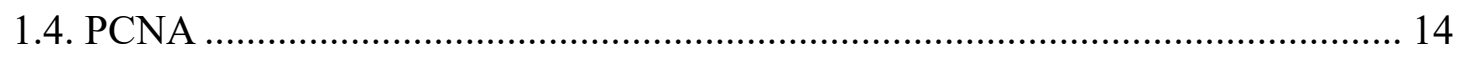

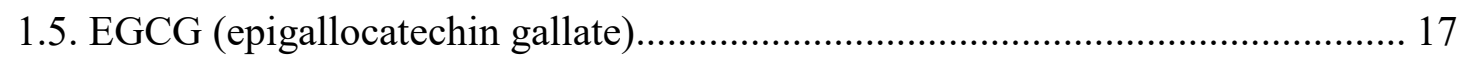

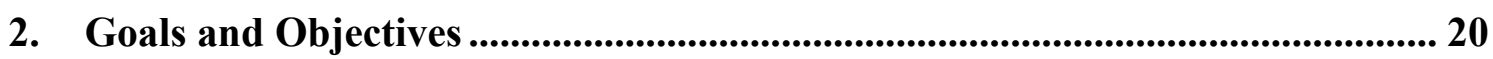

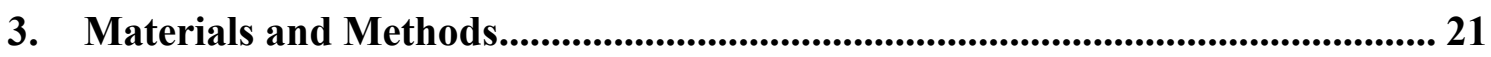

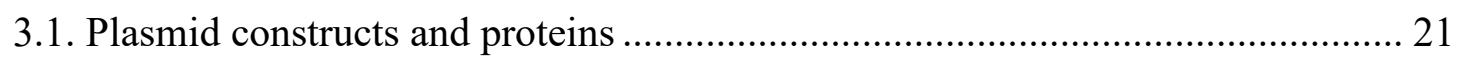

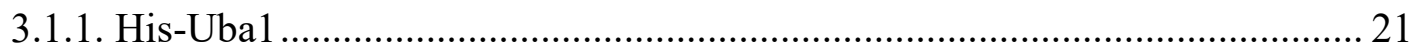

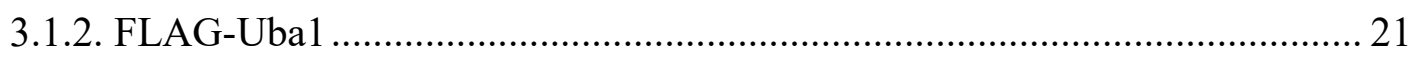

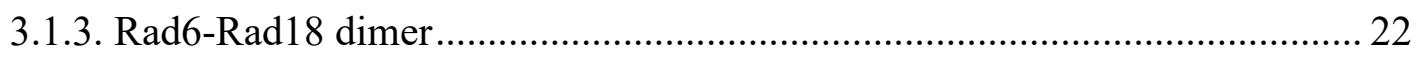

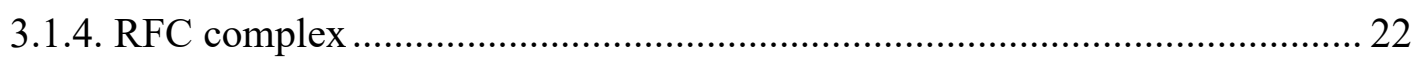

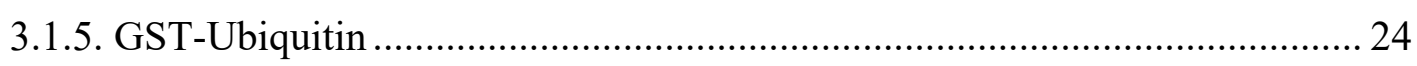

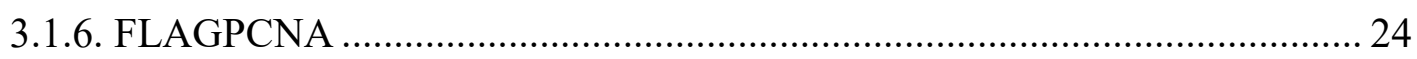

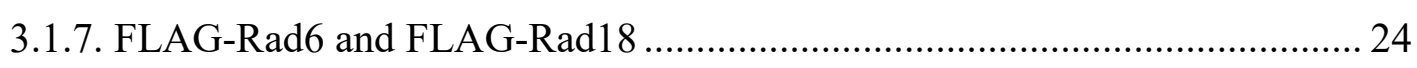

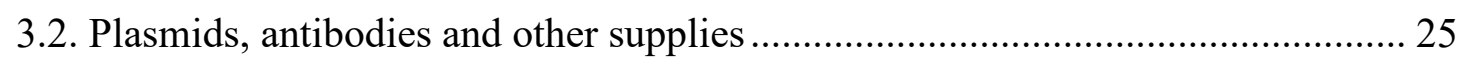

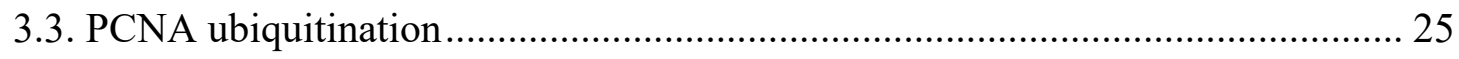

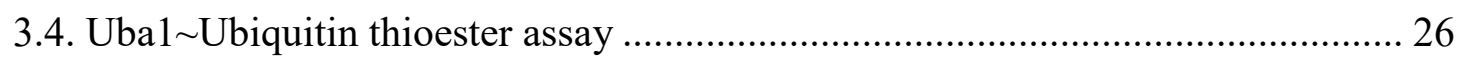

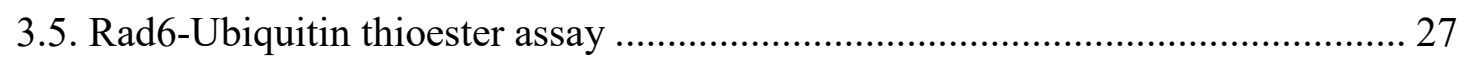


3.7. Alpha assay for Rad18 auto-ubiquitination.................................................... 28

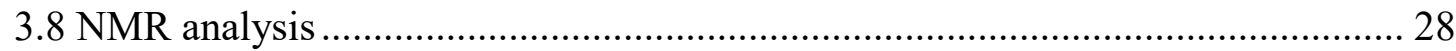

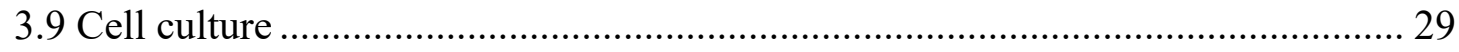

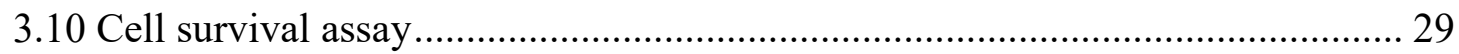

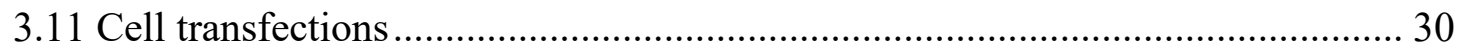

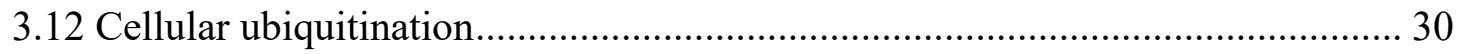

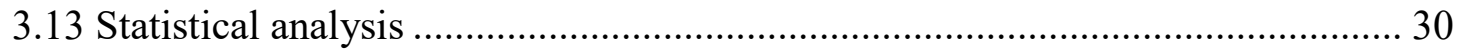

4. Results and Conclusions............................................................................................. 33

4.1. Development of a high-throughput screening assay to discover modulators of

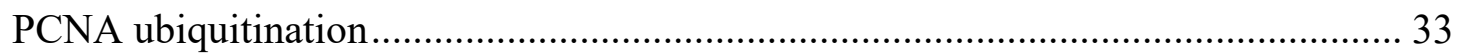

4.2. Optimization of the PCNA-ubiquitination-based Alpha assay ........................... 34

4.3. Final optimized conditions for the high-throughput Alpha assay for PCNA

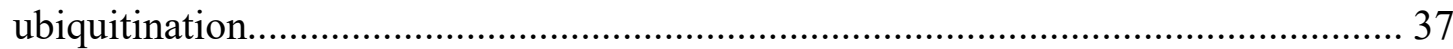

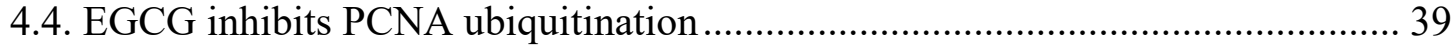

4.5. Dose-response analysis for different compounds in PCNA ubiquitination ......... 40

4.6. EGCG blocks Uba1-ubiquitin thioester formation............................................ 42

4.7. Effects of EGCG and myricetin on Ubal are reversible ................................... 43

4.8. Dose-response analysis for Uba1 ubiquitin thioester formation ....................... 43

4.9. Nuclear magnetic resonance (NMR) shows that EGCG binds Uba1 .................. 46

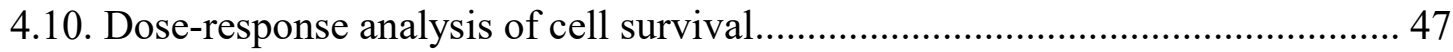


4.11. Ubal or ubiquitin protects the cells from cytotoxic effects of EGCG and EGCG reduces the global ubiquitination in cells.

4.12. SAR with EGCG analogs reveals distinct groupings of congeners by structure, activity profile and mechanisms of action.

4.13. Robust high-throughput assays to assess discrete steps in PCNA

ubiquitination

4.13.1. Development of an Alpha assay for Uba1 ubiquitin thioester formation ...... 55

4.13.2. Development of an Alpha assay for Rad6 ubiquitin thioester formation....... 55

4.13.3. Development of a Rad6-Rad18 interaction assay

4.13.4. Development of a Rad18 autoubiquitination assay 58

4.14. Validation of the assays 59

5. Discussion 62

6. Acknowledgment 73

7. References 75

8. Summary 95

9. Összefoglaló 98

10. List of Publications 


\section{List of Abbreviations}

2D NOESY: 2D Nuclear Overhauser Effect Spectroscopy

ATP: Adenosine triphosphate

BER: Base excision repair

Bio-Ub: Biotin-ubiquitin

Cat: Catechin

CI: Confidence interval

DDR: DNA damage response

DG: Dodecyl gallate

DM: Dihydromyricetin

DMSO: Dimethyl sulfoxide

DNA: Deoxyribonucleic acid

DSB: Double-strand break

DTT: Dithiothreitol

ECG: Epicatechin gallate

EDTA: Ethylenediaminetetraacetic acid

EGC: Epigallocatechin

EGCG: Epigallocatechin gallate

ELISA: Enzyme-linked immune sorbent assay

FBS: Fetal bovine serum 
FRET: Fluorescence resonance energy transfer

GA: Gallic acid

GST: Glutathione S-transferase

HECT: Homologous to the E6-AP Carboxyl Terminus

HLTF: Helicase-like transcription factor

HRP: Horseradish peroxidase

HR: Homologous recombination

HTS: High throughput screening

$\mathrm{IC}_{50}$ : Half maximal inhibitory concentration

IDCL: Interdomain-connecting loop

IPTG: Isopropyl- $\beta$-D-thiogalactoside

K164: Lysine 164 residue of PCNA

$\mathrm{K}_{\mathrm{d}}$ : Dissociation constant

MMR: Mismatch repair

Myr: Myricetin

N/A: Not applicable

NF-кB: Nuclear factor kappa-light-chain-enhancer of activated B cells

NHEJ: Non-homologous end joining

NMR: Nuclear magnetic resonance

OE: Overexpression 
OG: Octyl gallate

PCNA: Proliferative cell nuclear antigen

PG: Propyl gallate

Pol $\alpha$ : Polymerase $\alpha$

PPi: Pyrophosphate

RFC: Replication factor C

RING: Really Interesting New Gene

RNA: Ribonucleic acid

RNS: Reactive nitrogen species

ROS: Reactive oxygen species

RPA: Human replication protein A

S phase: Synthesis phase

S/B: Signal-to-background ratio

S/N: Signal-to-noise ratio

SAR: Structure-activity relationship

SE: Standard error

SHPRH: Smf2 histone linker PHD ring helicase

SSMD: strictly standardized mean difference

STD: Saturation transfer difference

SUMO: Small ubiquitin-like modifier 
TLS: Tranlesion synthesis

Tr-NOE: Transferred Nuclear Overhauser Effect

Uba1: Ubiquitin-activating enzyme 1

UBL: Ubiquitin like proteins 


\section{Introduction}

The discovery of small-molecule inhibitors targeting different post-translational modifications has been a hot topic since the last decade. In general, post-translational modifications are important events that signal the fate of myriad proteins in the cell. Here, we have focused on a specialized post-translational modification, i.e. ubiquitination of proliferating cell nuclear antigen (PCNA), where 76-amino-acid residue ubiquitin gets covalently attached to PCNA, which recruits translesion DNA synthesis (TLS) polymerases which are inherently error-prone and lead to mutagenesis and carcinogenesis. Our project is focussed on the discovery of small-molecule inhibitors of PCNA ubiquitination so that TLS inhibition can become a part of cancer treatment. The small-molecule inhibitors of PCNA ubiquitination could synergize with other anti-cancer treatments and reverse drug tolerance in patients who are refractile to present treatments.

Upon DNA damage, lesions can be left unrepaired from classical DNA repair mechanisms and these damages can stall the replication fork during the S-phase of the cell cycle. Here, the specialized translesion DNA polymerases come into the play which are specialized to bypass these lesions, a process known as translesion DNA synthesis (TLS). Further, TLS gets activated by the monoubiquitination of PCNA at the stalled replication fork which involves Uba1 (UBE1) as E1 ubiquitin-activating enzyme, Rad6 as a ubiquitinconjugation enzyme complex with Rad18 as E3 ubiquitin ligase and PCNA which is the ultimate substrate of ubiquitination.

There can be different ways of targeting error-prone translesion DNA synthesis either by inhibition of activity of an individual protein involved in PCNA ubiquitination, by direct binding, disruption of a specific regulatory domain/function and/or by blocking regulatory 
protein-protein interactions. In order to target TLS we have developed a high throughput step-specific screening assay to discover small-molecule inhibitors of PCNA ubiquitination, ultimately epigallocatechin gallate (EGCG) an inhibitor of PCNA ubiquitination targeting Uba1 protein in the ubiquitination cascade was discovered.

\subsection{DNA replication}

All living organisms store information about growth and functioning in the form of DNA. DNA replication is an essential, highly organized, strictly controlled and evolutionarily conserved process, carried out by complex machinery, involving a myriad of proteins and enzymes working together to form a large complex, the replisome.

The replication of the genome requires DNA unwinding by a special class of proteins called helicases. The replicative helicases are multi-subunit protein complexes. The eukaryotic replicative helicase is composed of 11 subunits, requiring an assembly of two subcomplexes and one protein. The hetero-hexameric MCM2-7 helicase is activated by forming a complex with Cdc45 and the hetero-tetrameric go-ichi-ni-san (GINS) complex forming a Cdc45-Mcm2-7-GINS (CMG) complex (Figure 1), the replicative helicase complex (Boehm, Gildenberg, and Washington 2016). After unwinding, the singlestranded DNA becomes unstable and can be exposed to endonucleases. Human replication protein A (RPA) stabilizes the single-stranded DNA by binding to it (Wold 1997; Wobbe et al. 1987). The synthesis of DNA requires an RNA primer, the synthesis of which is catalyzed by primase and DNA polymerase $\alpha(\mathrm{Pol} \alpha)$. The Pol $\alpha$-primase complex is required by the processive classic polymerases for bulk DNA synthesis (Pellegrini 2012). The RNA primer attaches itself to the template strand, replication factor $\mathrm{C}$ (RFC) binds to the primer-template junction and catalyzes the loading of PCNA, which encircles DNA. PCNA will recruit DNA polymerases such as polymerase alpha, delta and 
epsilon (L. M. Johnson et al. 1985). DNA polymerases move continuously in one direction on the leading strand and discontinuously on the lagging strand by the formation of short fragments known as Okazaki fragment, Okazaki fragments are short sequences of DNA nucleotides (approximately 150 to 200 base pairs long in eukaryotes) which are synthesized discontinuously and later linked together by the enzyme DNA ligase to create the lagging strand during DNA replication (Figure 1) (Sugimoto, Okazaki, and Okazaki 1968; Sugimoto et al. 1969; Okazaki and Okazaki 1969). During the replication of Okazaki fragments, thousands of nicks are formed that undergo efficient processing by the coordination between DNA polymerase $\delta$ and FLAP endonuclease (FEN1). When the replicative polymerase reaches the end of the DNA synthesis on the Okazaki fragment, it partially displaces this fragment by the ongoing DNA synthesis and a flap structure is formed through the activity of flap structure-related endonuclease (FEN1); this structure is cut out and the resulting nick is sealed by DNA ligase I. The coordination of polymerases and FEN1 is more efficient in polymerase $\delta$ than other polymerases (Garg et al. 2004). PCNA elevates the efficiency of the DNA replicative polymerase, which replicates the bulk of the DNA (Moldovan, Pfander, and Jentsch 2007).

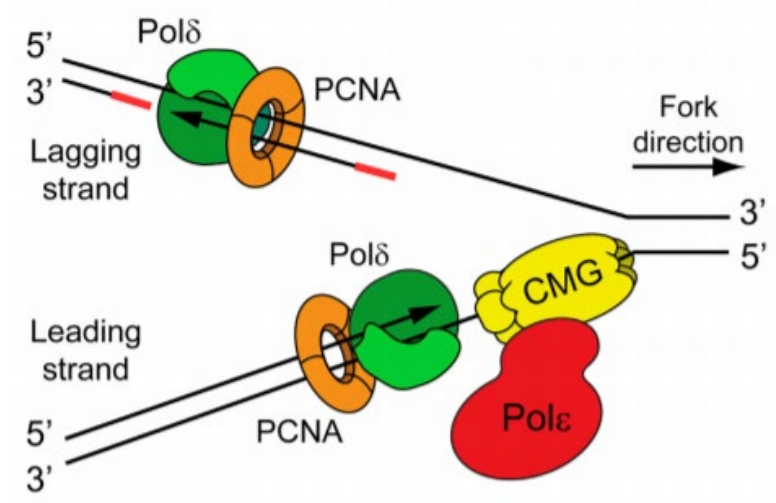

Figure 1. Schematic representation of the eukaryotic replication fork. The red bars represent the Okazaki fragments on the lagging strand. The Pole replicating at leading strand and Pol $\delta$ is replicating the lagging strand template. The CMG complex, a replicative helicase complex (R. E. Johnson et al. 2015). 


\subsection{DNA damage}

Genomic DNA is consistently exposed to various endogenous and exogenous damaging agents (Mazouzi, Velimezi, and Loizou 2014; Lindahl and Barnes 2000). Endogenous DNA damaging factors are the products of cellular metabolism such as reactive oxygen species (ROS), lipid peroxidation, propano adducts, ethano adducts and malondialdehyde induced damage, etc (De Bont and van Larebeke 2004). Exogenous sources or directacting agents are ultraviolet radiations, ionizing radiations, nitrogen mustard, formaldehyde, nitrosamines, etc. (Jena 2012). If damaged DNA remains unrepaired, it can lead to mutagenesis and thus carcinogenesis (Figure 2) (Negrini, Gorgoulis, and Halazonetis 2010; Shen 2011).

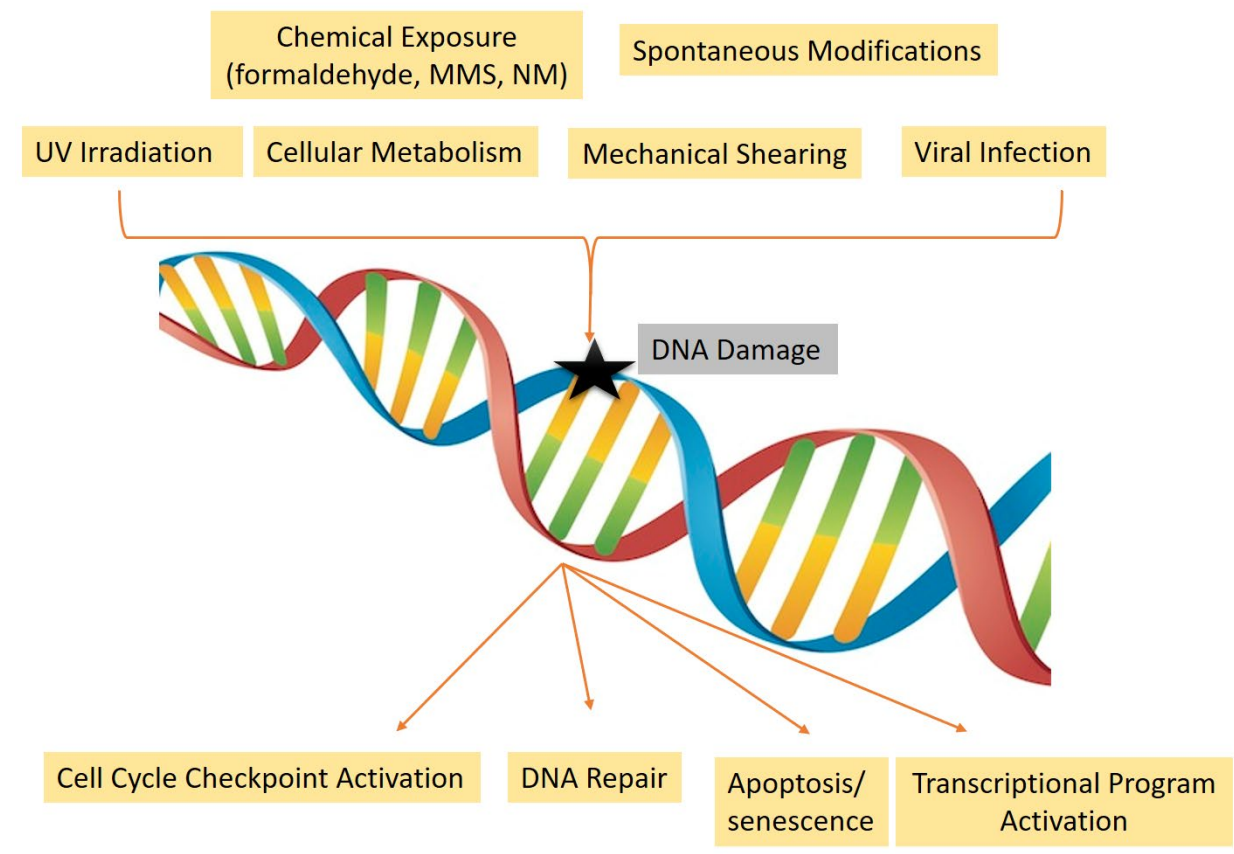

Figure 2. DNA damage response. Endogenous and exogenous sources causing DNA damage trigger DNA damage response (DDR), which consists of an intricate network between cell cycle checkpoint control, DNA repair and transcriptional regulation or, in case of excessive DNA damage, programmed cell death mechanisms.

\subsection{DNA damage tolerance/bypass}

Cells have an amazing system to handle assault to DNA, the so-called DNA damage response network. DNA damage is caused by different factors and the degree of damage 
can vary, thus, different repair mechanisms have evolved to heal the damaged regions (Friedberg 2005). These mechanisms include direct reversal by photolyase (Sancar 1996), homologous recombination (HR) (Helleday et al. 2007), non-homologous end joining (NHEJ) (Weterings and Van Gent 2004), nucleotide excision repair (NER) (Sancar 1996; Fousteri and Mullenders 2008), base excision repair (BER) (Sancar 1996; Parikh et al. 1998) and mismatch repair (MMR) (Hsieh and Yamane 2008; Longley, Pierce, and Modrich 1997; Jiricny 2006) (see Figure 3).

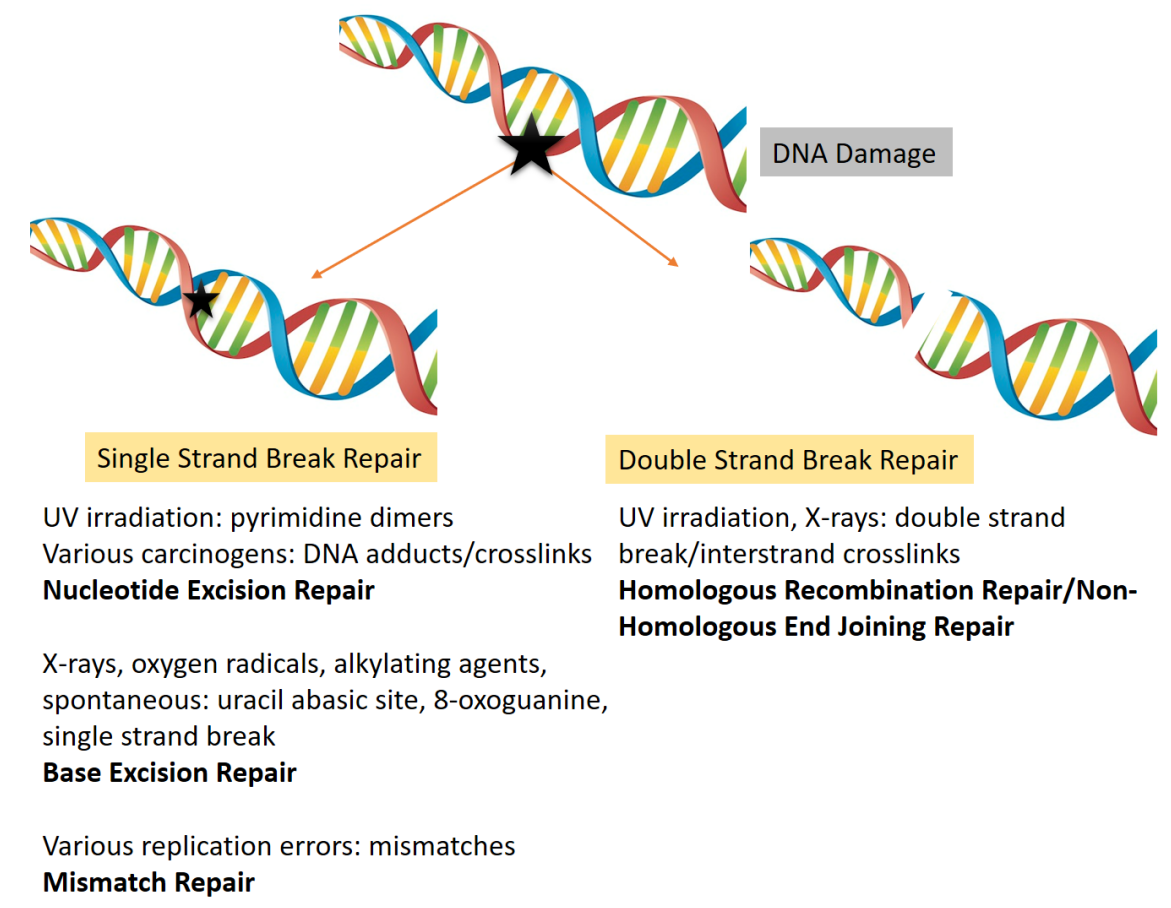

Figure 3. DNA damage and different DNA repair pathways.

DNA damage that is not repaired before the $\mathrm{S}$ phase acts as an obstacle for the replication, which can lead to replication stalling. The stalled replication fork is unstable; it can break, which results in double-strand breaks (DSB), chromosomal aberrations and genomic rearrangements that threaten the viability of the cell or the organism (Negrini, Gorgoulis, and Halazonetis 2010; Shen 2011; Pikor et al. 2013; Macheret and Halazonetis 2015). DNA damage tolerance (DTT) pathways specialize in the rescue of the stalled replication 
fork. There are two major DTT pathway exist first is error-prone TLS and other is errorfree template switching. The TLS is characterized by the switching of classical DNA polymerases to low-fidelity translesion DNA polymerases (TLS). In contrast, template switching is proposed to use a recombination-like mechanism by which the nascent DNA of the sister chromatid is utilized as a temporary template for replication (Branzei 2011) (Figure 4). TLS polymerases are so-called Y-family polymerases such as Pol $\eta$, Pol ı, Pol $\kappa$ and Rev1 (Hoitsma et al. 2020). These polymerases have a wider active center; thus, they can incorporate nucleotides across the damaged ones (Shcherbakova and Fijalkowska 2006; Lehmann et al. 2007). TLS polymerases can introduce nucleotides in an error-free or in an error-prone way. In an error-prone way, incorporation of the wrong nucleotide or lesion bypass can lead to mutagenesis and carcinogenesis.

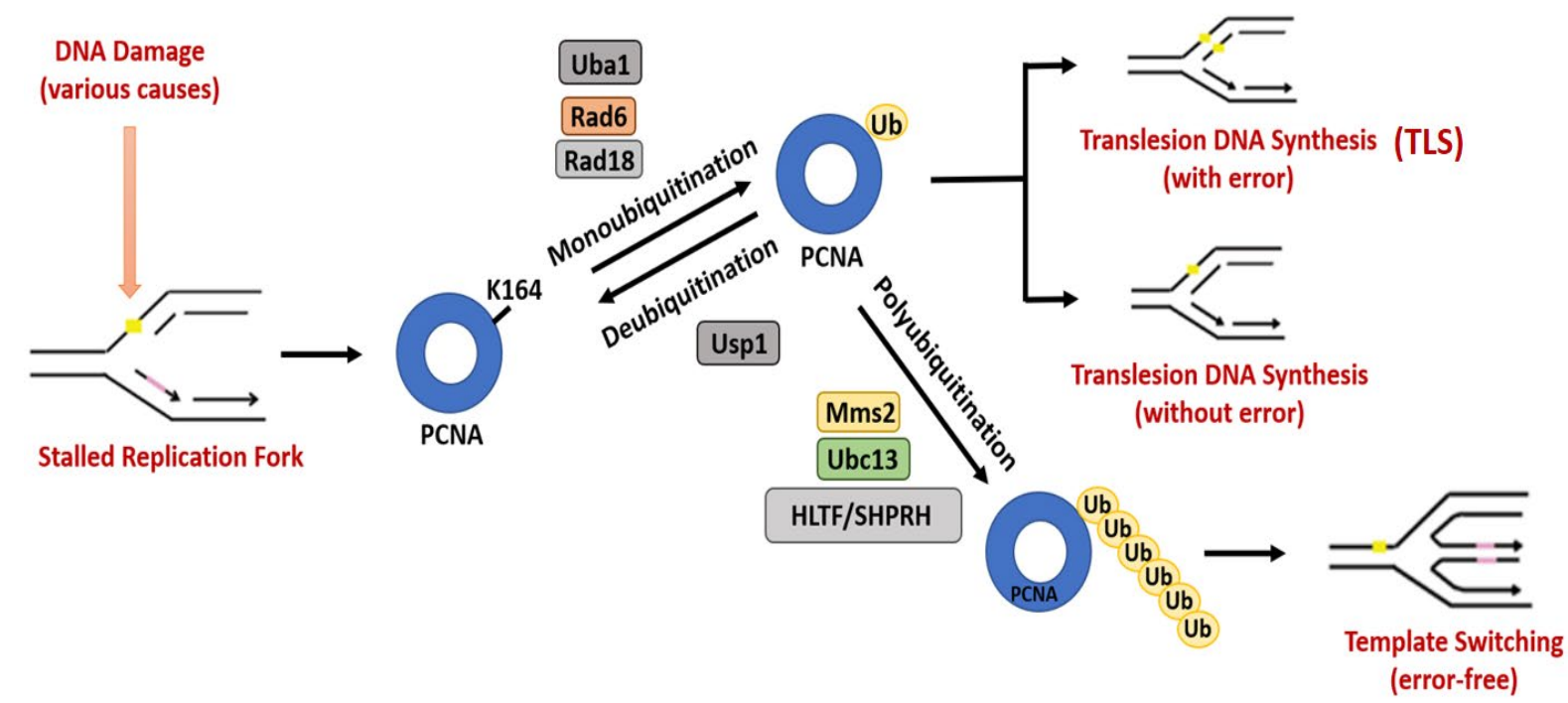

Figure 4. Schematic representation of major DNA repair processes at stalled replication forks. Mutagenic agents damage DNA triggering monoubiquitination of proliferating cell nuclear antigen (PCNA) by the E1 ubiquitin-activating enzyme Uba1, the E2 ubiquitinconjugating enzyme Rad6 and the E3 ubiquitin ligase Rad18. Monoubiquitinated PCNA activates translesion DNA synthesis (TLS), an error-prone DNA damage tolerance process. Monoubiquitinated PCNA can undergo subsequent polyubiquitination in the presence of Mms2, Ubc13 and HLTF or SPRH, which initiates error-free template switching. 


\subsection{PCNA}

Proliferating cell nuclear antigen (PCNA) belongs to the family of DNA sliding clamps ( $\beta$ clamp), which is highly conserved. PCNA is a homotrimer, which encircles the DNA and is able to move freely in both directions. PCNA has two globular domains, connected by an ICDL inter-domain connecting loop (Figure 5) (Krishna et al. 1994). PCNA acts as a processivity factor for DNA polymerases. It also has a key role in the regulation of DNA damage tolerance pathways. PCNA is loaded onto DNA with the help of a protein complex called replication factor C (RFC) (Majka and Burgers 2004).

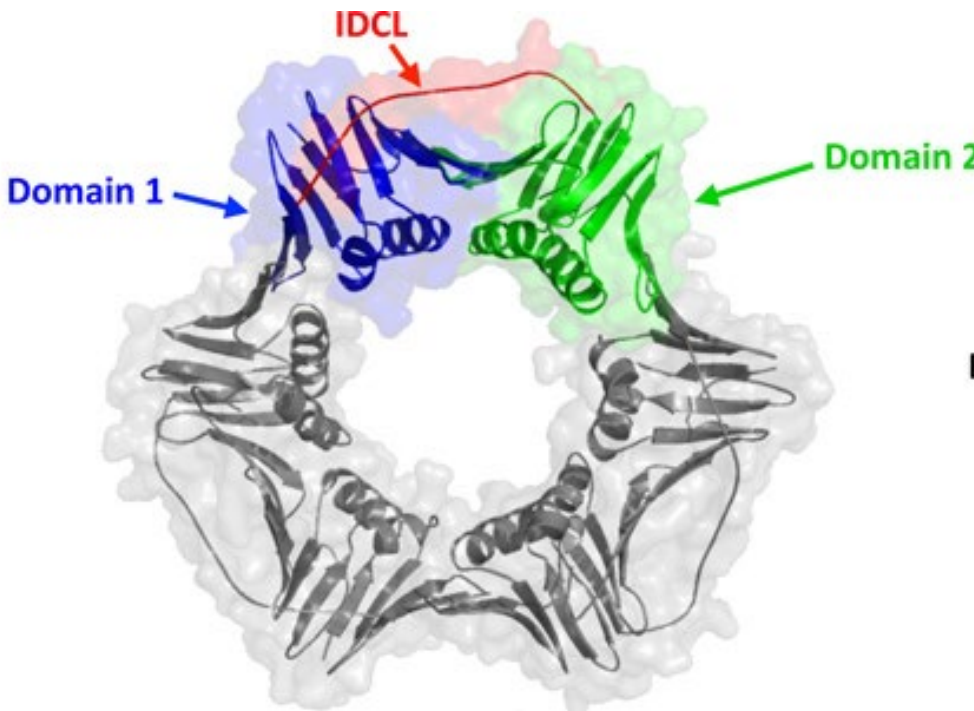

Front view

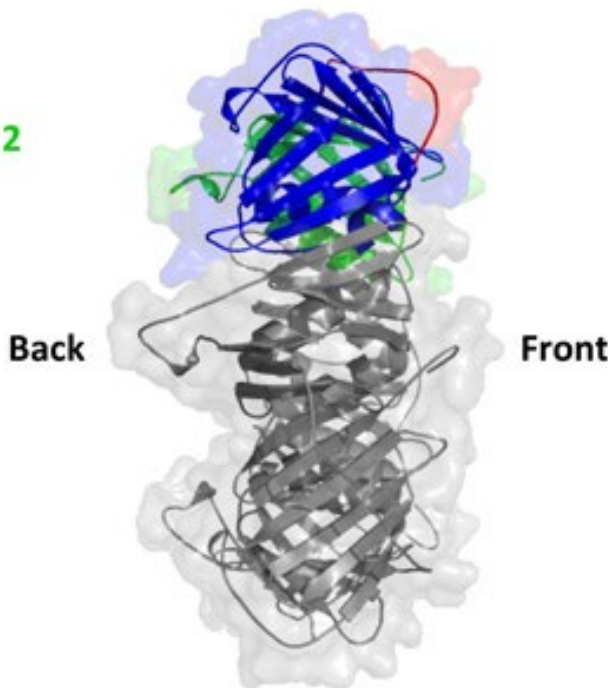

Side view

Figure 5. Ribbon diagram of the PCNA trimer (PDB ID: 1PLQ) shown from the front view and the side view. Domain 1 is blue, domain 2 is green and the inter-domain connecting loop (IDCL) is red (Krishna et al. 1994).

In response to the stalled replication fork, PCNA undergoes monoubiquitination at the Lysine 164 (K164) residue or a polyubiquitin chain gets linked via ubiquitin's lysine 63 residue (Kanao and Masutani 2017; Moldovan, Pfander, and Jentsch 2007). PCNA monoubiquitination requires three steps that are catalyzed by three distinct enzymes. First, ATP-dependent activation of the carboxy terminus of ubiquitin is catalyzed by the E1 (the ubiquitin-activating enzyme Uba1) through the formation of a ubiquitin-adenylate 
intermediate, which then reacts with the active-site cysteine on Uba1, yielding a highenergy Uba1 ubiquitin thioester intermediate. Second, transfer of the ubiquitin moiety to the catalytic cysteine on the E2 ubiquitin-conjugating enzyme (Rad6) occurs to form a Rad6 ubiquitin thioester intermediate. Third, ubiquitin is transferred from Rad6 specifically to the side-chain amine of the K164 residue on PCNA to form a PCNAubiquitin isopeptide bond, mediated by the E3 ubiquitin ligase Rad18 in complex with Rad6 (Kanao and Masutani 2017; Leung et al. 2019).

Monoubiquitination of PCNA triggers the TLS pathway and prevents binding of replication factors to PCNA, while polyubiquitination initiates an event called template switching (Kanao and Masutani 2017; Leung et al. 2019; Gallo and Brown 2019). Interestingly, TLS polymerases (Pol $\eta$, Pol 1 and Rev1) are themselves substrates for monoubiquitination. It has been proposed that modifications may facilitate the sequential action of different polymerases. Several scenarios can take place at the stalled replication fork. Monoubiquitinated PCNA can recruit TLS polymerases on the basis of their capability of introducing nucleotides into the DNA lesion, or monoubiquitinated PCNA can specifically recruit TLS polymerases via the ubiquitin-binding sites in these enzymes. According to another scenario, monoubiquitination of the first TLS polymerase would occur only if it is unable to repair the lesion. The intramolecular interaction between its ubiquitin and ubiquitin-binding domain would signal for it to be eliminated as an unsuccessful TLS polymerase and another one will be recruited to the lesion. The errorfree mode might be initiated when none of the TLS polymerases are able to heal the lesion; thus, the prolonged stalling of the replication fork triggers Rad5-Ubc13-Mms2-dependent PCNA polyubiquitination. How exactly the error-free pathway proceeds is currently poorly understood (Moldovan, Pfander, and Jentsch 2007; Bienko et al. 2005). 
TLS is an error-prone process, since TLS polymerases lack 3'-5' proofreading activity, although there are some TLS polymerases that can replicate DNA lesions without causing errors (Livneh, Ziv, and Shachar 2010; Sale 2013; Zhao and Todd Washington 2017; Powers and Washington 2018). Polyubiquitination of PCNA is mediated by the E2 enzyme complex (Mms2-Ubc13) in association with the E3 (Rad5) protein orthologs helicase like transcription factor (HLTF) or Smf2 histone linker PHD ring helicase (SHPRH) (J. R. Lin et al. 2011; Unk et al. 2010; Gangavarapu et al. 2006; Parker and Ulrich 2009), through a pathway that yields a polyubiquitination chain distinct from that which serves as a tag for proteasomal degradation. PCNA ubiquitination is reversed by ubiquitin-specific peptidase-1, helping to control PCNA ubiquitination levels, TLS and template switching. What determines the "decision" of whether PCNA should undergo monoubiquitination or polyubiquitination is currently unknown. The lysine 164 residue of PCNA has also been found to be capable of undergoing modification by ubiquitin-like proteins such as small ubiquitin-like modifier (SUMO), neural precursor cell expressed, developmentally down-regulated 8 (NEDD8) and interferon-stimulated gene 15 (ISG15), through distinct E1-E2-E3 cascades for each, with some overlap in certain cases (Gali et al. 2012; Hoege et al. 2002; Stelter and Ulrich 2003; L. Haracska et al. 2004). However, the functions of these antagonistic UBL post-translational modifications of PCNA are currently unclear. SUMOylation has been proven to regulate homologous recombination, NEDDylation limits recruitment of TLS polymerase $\eta$ under conditions of oxidative stress and ISGylation controls the release of TLS polymerases from PCNA complexes and thus helps terminate TLS (Hoege et al. 2002; Guan, Yu, and Zheng 2018; Park et al. 2014). These differential modifications appear to finely regulate the complex and diverse functions of PCNA. A single PCNA trimer may have different modifications on each subunit, thus potentially leading to hybrid complexes of a composite function. 


\subsection{EGCG (epigallocatechin gallate)}

EGCG is the major catechin found in green tea extract. It has three heterocyclic rings that favor electron delocalization leading to quenching of free radicals. Green tea polyphenols particularly its most active and abundant component epigallocatechin-3-gallate (EGCG) has gained a lot of attention as a potential therapeutic agent for preventing neurodegenerative, inflammatory diseases and cancer mainly due to their beneficial effects on human health (Figure 6, showing various properties and application of EGCG (Chu et al. 2017)). It also has redox properties; reacts with reactive oxygen species (ROS). It inhibits protein tyrosine nitration induced by oxidative stress in platelet cells. As an antioxidant, it can improve the function of mitochondria (Sabetkar et al. 2008). EGCG has also been reported to cause self-oxidization and function as a pro-oxidant by producing hydroxyl radicals, hydrogen peroxide and quinonoid intermediates causing cytotoxicity (Li et al. 2010; Sakagami et al. 2001; G.-Y. Yang 2000; Nakagawa et al. 2004). EGCG also affects inflammation and other immune responses (R. Singh, Akhtar, and Haqqi 2010). Inflammation triggers the release of proinflammatory cytokines, reactive oxygen species (ROS) and reactive nitrogen species (RNS). ROS/RNS are related to the activation of transcription factor $\mathrm{NF}-\kappa \mathrm{B}$ and activator protein (AP-1), which upregulate the expression of a variety of inflammatory genes. EGCG has been shown to inhibit transcription factor NF- $\mathrm{BB}$ and AP-1 to downregulate the expression of $\mathrm{iNOS}$ and COX-2 by scavenging the NO, peroxynitrite and other ROS/NOS and decreases the production of inflammatory factors (Kamata and Hirata 1999; Nagai et al. 2002; E. Tedeschi, Suzuki, and Menegazzi 2002; Elisa Tedeschi et al. 2004). 


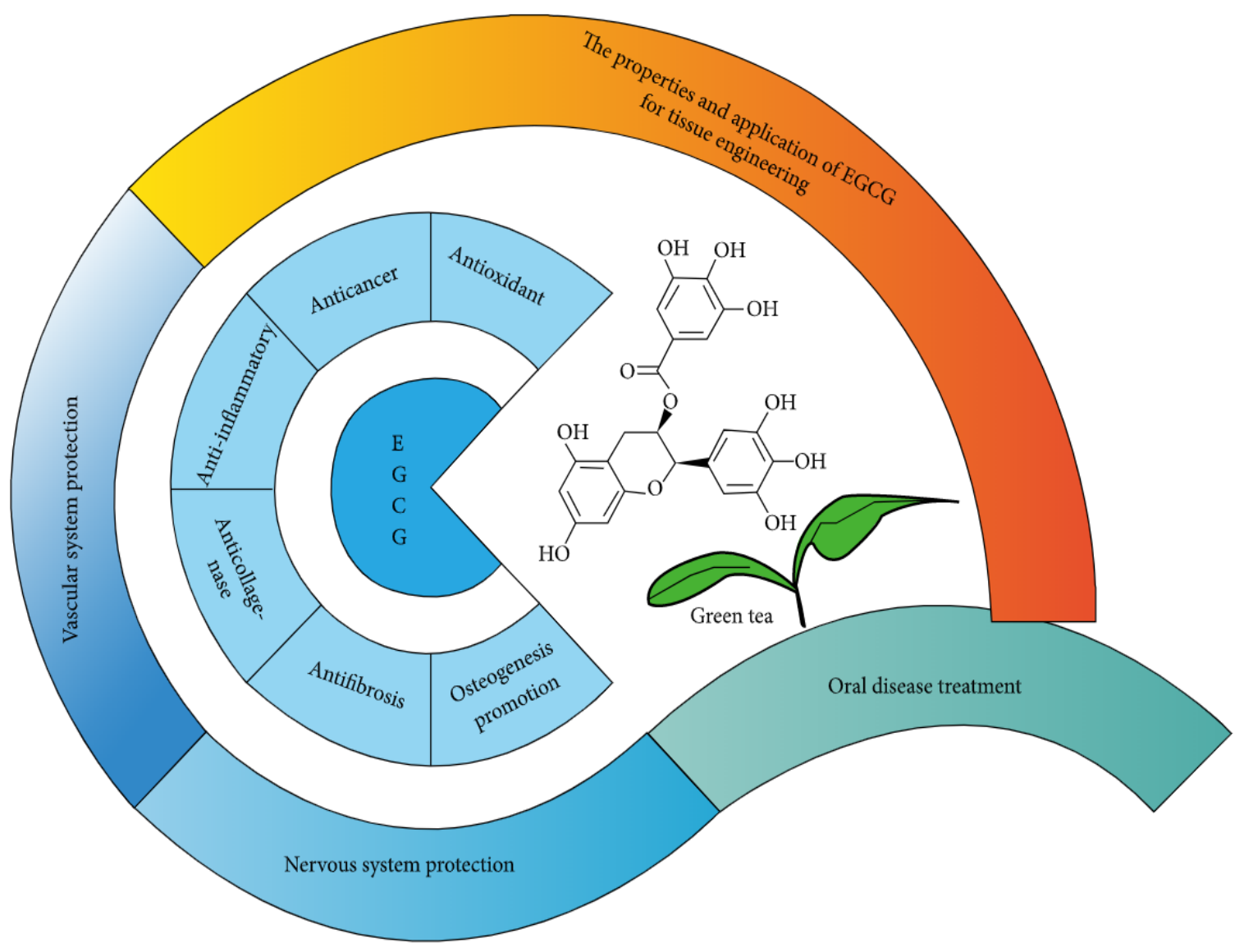

Figure 6. Cartoon showing the application and properties of EGCG (Chu et al. 2017).

In a number of studies, EGCG has been shown to have antifibrosis properties (Yasuda et al. 2009; M. C. Zhen et al. 2006; Weber et al. 1994; Kitamura et al. 2012). EGCG acts by blocking the translocation of NF- $\mathrm{kB}$ from the cytoplasm to the nucleus. Hepatic fibrosis is one of the many complications of chronic liver diseases, which leads to hepatic cirrhosis (Lee et al. 2012; Moses et al. 2015). In hepatic cirrhosis and hepatocarcinoma, it has been observed that stellate cells are the major source of extracellular matrix (Friedman and Bansal 2006; Friedman 1997; 1999). EGCG has inhibitory activity on the activation and proliferation of hepatic stellate cells and the biosynthesis of collagen in rat models (Nakamuta et al. 2005; Higashi et al. 2005; Sakata et al. 2004). EGCG has been very effective and useful in many oral treatment studies mainly due to its anti-inflammatory effect and inhibition of bone absorption ability (C. Y. Wang, Tani-Ishii, and Stashenko 
1997; J. Y. Hong et al. 2015; Shin et al. 2014; Cho et al. 2013; M. chuan Zhen et al. 2007; Kostopoulos and Karring 1994). EGCG also exhibits a strong anticancer activity, which has been reported by various laboratories (P. Wang, Henning, and Heber 2010; Thangapazham et al. 2007; Zaveri 2006). EGCG inhibits many cell signaling pathways that are involved in cancer development (Khan et al. 2006; J. Zhang et al. 2016). It has been reported in many in vitro studies that EGCG has inhibitory effects on growth and induces apoptosis in many human cancer cell lines such as colon, breast, lung, leukemic and melanoma (Khan et al. 2006; Aggarwal and Shishodia 2006; J. Zhang et al. 2016). EGCG is active in inducing apoptosis and inhibiting metastasis in a variety of cancer cell lines via cell cycle arrest or by activation of the MAP kinase cascade (J. K. Lin et al. 2000). 


\section{Goals and Objectives}

The main goal of the project was to develop various high-throughput step-specific PCNA ubiquitination assays and discover modulators of the PCNA ubiquitination reaction cascade. PCNA ubiquitination is a key early event in DNA damage tolerance processes, it recruits TLS polymerases at stalled replication fork. The TLS polymerases are inherently error-prone and they can lead to mutagenesis and carcinogenesis. So, PCNA ubiquitination is a potential therapeutic target in combination with currently known cancer therapeutics.

The following aims were envisaged:

- To develop a robust, reliable and sensitive high-throughput assay to quantitatively measure PCNA ubiquitination, based on the amplified luminescent proximity homogeneous assay (Alpha) technology.

- Carry out screening of chemical libraries to discover modulators of the PCNA ubiquitination reaction.

- Hit characterization from screening and structure-activity relationship (SAR) studies.

- To develop secondary assays based on the Alpha system for secondary screening to reveal the specific step and protein targeted in the reaction. 


\section{Materials and Methods}

\subsection{Plasmid constructs and proteins}

\subsubsection{His-Uba1}

His-tagged human Ubal in the pET3a bacterial expression vector (Addgene plasmid \#63571) was expressed in Escherichia coli strain BL21-CodonPlus(DE3)-RIL (Agilent). The cells were centrifuged and washed in $1 \times$ phosphate-buffered saline (PBS). The cell suspensions were dropped into liquid nitrogen and the resulting frozen beads were ground with a SPEX SamplePrep 6775 Freezer/Mill. The lysates were centrifuged and the supernatant was applied to Ni-NTA agarose (Machery-Nagel) column. Following repeated washings, the protein was eluted from the column with $250 \mathrm{mM}$ imidazole, then dialyzed against $20 \mathrm{mM}$ Tris- $\mathrm{HCl}, \mathrm{pH}$ 7.5, $150 \mathrm{mM} \mathrm{NaCl}, 10 \%$ glycerol, 0.01\% NP-40 and $1 \mathrm{mM}$ freshly added dithiothreitol (DTT). The concentrations were determined by measuring absorbance at $280 \mathrm{~nm}$ using a NanoDrop ND 1000 spectrophotometer instrument. The extinction coefficient of proteins was determined by using the ProtParam tool (https://web.expasy.org/protparam/). Finally, by using the Beer-Lambert Law concentrations were calculated.

\subsubsection{FLAG-Uba1}

FLAG-tagged human Uba1 was introduced into the pBJ842 yeast expression vector with the Leu marker. The FLAG-Uba1 was expressed in S. cerevisiae BJ5654 strain. The cells were collected at OD 0.8-1, centrifuged and washed with 1x PBS buffer. The cells were broken using a cryogenic method (SPEX cryogenic 6775 freezer/mill). Cell pellets were cleared by centrifugation to remove cell debris. The supernatant was transferred onto separation columns containing glutathione Sepharose 4B beads (GE Healthcare). The lysate was allowed to pass through the column followed by washings. The protein was 
eluted from the column by incubating with PreScission Protease. The concentration was determined as mentioned above.

\subsubsection{Rad6-Rad18 dimer}

Both human Rad6B and GST-fused human Rad18 constructs (each cloned into the pBJ842 yeast expression vector, which contains Leu and Trp auxotrophic markers) were introduced into the $S$. cerevisiae BJ5654 strain. The cells were grown in omission media (-Leu, - Trp), then collected when reaching $\mathrm{OD}_{600} 0.8-1$, centrifuged and washed with $1 \times$ PBS. The cells were resuspended in yeast lysis buffer consisting of $50 \mathrm{mM}$ HEPES, $\mathrm{pH}$ 7.5, $50 \mathrm{mM} \mathrm{KCl}, 267 \mathrm{mM} \mathrm{NaCl}, 10 \%$ sucrose, $0.5 \mathrm{mM}$ EDTA and $2.8 \mathrm{mM} \beta-$ mercaptoethanol. The cell lysate was then dropped into liquid nitrogen, ground with a SPEX SamplePrep 6775 Freezer/Mill, collected into $1.5 \mathrm{ml}$ microcentrifuge tubes and centrifuged. The supernatant was applied to a glutathione Sepharose 4B (GE Healthcare) column, followed by repeated washings in $20 \mathrm{mM}$ Tris-HCl, $\mathrm{pH} 7.5,10 \%$ glycerol, $0.01 \%$ $\mathrm{NP}-40$ and $1 \mathrm{mM}$ DTT at progressively lower $\mathrm{NaCl}$ concentrations $(3 \times 500 \mathrm{mM}, 3 \times 250$ $\mathrm{mM}, 1 \times 150 \mathrm{mM})$. The GST moiety was cleaved with PreScission Protease (GE Healthcare) with incubation for $2 \mathrm{~h}$ at $4{ }^{\circ} \mathrm{C}$ with light shaking and the dimer was eluted with a $1.5 \times$ bed volume equivalent of $20 \mathrm{mM}$ Tris- $\mathrm{HCl}, \mathrm{pH} 7.5,150 \mathrm{mM} \mathrm{NaCl}, 10 \%$ glycerol, $0.01 \%$ NP-40 and $1 \mathrm{mM}$ DTT. The concentration was determined as mentioned above.

\subsubsection{RFC complex}

The construct $\mathrm{pLANT}-2 / \mathrm{RIL}-\mathrm{RFC}\left[1^{\mathrm{s}}+5\right]$ was co-transformed with the construct pET(11a)-RFC[2+3+4] (Finkelstein et al. 2003) into the E. coli strain BL21CodonPlus(DE3)-RIL (Agilent), where $\mathrm{RFC1}^{\mathrm{s}}$ represents an N-terminally truncated form of the large RFC subunit (Gomes and Burgers 2000). The cells were plated and allowed to grow under selection with ampicillin $(100 \mu \mathrm{g} / \mathrm{ml})$ and kanamycin $(50 \mu \mathrm{g} / \mathrm{ml})$ overnight. 
A single transformant colony was then picked and grown in $2 \mathrm{ml}$ of Luria-Bertani medium containing ampicillin $(100 \mu \mathrm{g} / \mathrm{ml})$ and kanamycin $(50 \mu \mathrm{g} / \mathrm{ml})$ at $37{ }^{\circ} \mathrm{C}$ for $8 \mathrm{~h}$, then inoculated into a starter culture of 21 of Luria-Bertani medium containing ampicillin (100 $\mu \mathrm{g} / \mathrm{ml})$ and kanamycin $(50 \mu \mathrm{g} / \mathrm{ml})$ for $16 \mathrm{~h} .300 \mathrm{ml}$ of the starter culture was inoculated into 21 of Luria-Bertani medium and grown to $\mathrm{OD}_{600} 0.8$ at $37^{\circ} \mathrm{C}$. The cultures were cooled down to $16{ }^{\circ} \mathrm{C}$ and induced with $0.5 \mathrm{mM}$ isopropyl- $\beta$-D-thiogalactoside for $16 \mathrm{~h}$. All further steps were performed at $4{ }^{\circ} \mathrm{C}$.

The cells were harvested by centrifugation and then resuspended in HEG buffer ( $30 \mathrm{mM}$ HEPES, pH 7.6, 0.5 mM EDTA, 10\% glycerol, $5 \mathrm{mM} \beta$-mercaptoethanol) containing 150 $\mathrm{mM} \mathrm{NaCl}$. To lyse the cells, lysozyme was added to $0.4 \mathrm{mg} / \mathrm{ml}$ and the cells were subjected to three freeze-thaw cycles, followed by mechanical shearing through a hypodermic needle. The cell lysate was treated with Benzonase endonuclease, purity grade II (Merck), according to the manufacturer's protocol. The cell lysate was clarified by centrifugation. RFC was purified by chromatography over an SP-Sepharose column (bed volume of $6 \mathrm{ml}$ ), pre-equilibrated with $\mathrm{HEG}$ with $50 \mathrm{mM} \mathrm{NaCl}$, followed by a wash with $60 \mathrm{ml}$ of HEG buffer containing $50 \mathrm{mM} \mathrm{NaCl}$. Elution was carried with a gradient of 50-1,000 mM NaCl in a $60 \mathrm{ml}$ HEG buffer. Peak fractions were collected, pooled, then diluted with Ni-NTA buffer (30 mM HEPES, pH 7.6, $20 \mathrm{mM}$ imidazole, $500 \mathrm{mM} \mathrm{NaCl}$, $10 \%$ glycerol, $5 \mathrm{mM} \beta$-mercaptoethanol). The resulting sample was then applied to a NiNTA agarose (Machery-Nagel) column (bed volume of $500 \mu \mathrm{l}$ ), pre-equilibrated with NiNTA buffer. The column was then washed with $5 \mathrm{ml}$ of Ni-NTA buffer and proteins were eluted by a three-step gradient (100 mM, $250 \mathrm{mM}$ and $500 \mathrm{mM}$ imidazole), each with 1.5 $\mathrm{ml}$ overall volume. Fractions were tested for PCNA loading ability and peak fractions were aliquoted, frozen in liquid $\mathrm{N}_{2}$ and stored at $-80{ }^{\circ} \mathrm{C}$ until subsequent use. The concentration was determined as mentioned above. 


\subsubsection{GST-Ubiquitin}

GST-tagged human ubiquitin was expressed in the E. coli strain Dh5 $\alpha$. The cultures were grown in LB medium in the presence of ampicillin at $37^{\circ} \mathrm{C}$ on a shaker. The cells were induced with $200 \mu \mathrm{M}$ IPTG for $2 \mathrm{~h}$ at $37^{\circ} \mathrm{C}$ on a shaker. The cells were centrifuged and washed in 1x PBS buffer. The washed cells were ground with a cryogenic method using a SPEX cryogenic 6775 Freezer/Mill. The lysate was centrifuged at high speed and the clear cell lysate supernatant was transferred onto separation columns containing glutathione-sepharose 4B beads. The lysate was allowed to pass through the column followed by washings. The protein was eluted from the column using $20 \mathrm{mM}$ reduced glutathione. The concentration was determined as mentioned above.

\subsubsection{FLAGPCNA}

Constructs of human PCNA bearing GST and FLAG tags was cloned into the pBJ842 yeast expression vector. It waws used to prepare FLAG-tagged PCNA, with subsequent expression in the S. cerevisiae BJ5654 str-ain and purification with cleavage of the GST moiety, as above. The concentration was determined as mentioned above.

\subsubsection{FLAG-Rad6 and FLAG-Rad18}

Constructs were generated with the Gateway cloning technology (Life Technologies). Human Rad6 and human Rad18 cDNA sequences from entry constructs were recombined into a modified pGEX-6P-1 (Amersham) destination vector bearing GST and FLAG tags with a Gateway cassette via the LR Clonase II reaction (Invitrogen). Proteins were overexpressed in the E. coli strain BL21-CodonPlus(DE3)-RIL (Agilent). The proteins were purified with the removal of the GST moiety, as above. The concentration was determined as mentioned above. 


\subsection{Plasmids, antibodies and other supplies}

The pUC19 plasmid was transformed into Dh5 $\alpha$ cells. The cells were cultured for $16 \mathrm{~h}$ at $37^{\circ} \mathrm{C}$ on a shaker. Cells were collected from overnight culture by centrifugation and the plasmid was purified (Qiagen QIAprep Spin Miniprep Kit). The plasmid was nicked by digestion with the Nt. BstNBI enzyme overnight at $50^{\circ} \mathrm{C}$. The digested plasmid was checked using the agarose gel electrophoresis technique. The biotinylated human ubiquitin was purchased from Boston Biochemicals/R\&D Systems (UB-570). Streptavidin donor and anti-FLAG acceptor AlphaLisa and AlphaScreen beads were purchased from PerkinElmer. Anti-FLAG M2 monoclonal antibody conjugated to horseradish peroxidase (HRP) was purchased from Sigma-Aldrich. Anti-GST HRPconjugated antibody was purchased from GE healthcare. Anti-DNA polymerase delta catalytic subunit and anti-tubulin antibody were purchased from Santa Cruz Biotechnology. GST-tagged proteins were digested by PreScission Protease as per requirement. The chemical library was purchased from Avicor Ltd. The screening hit EGCG and its 11 analogs were purchased commercially from Avicor, Selleck Chemicals and Adooq Biosciences (Supplementary Table 1). EGCG and its analogs were dissolved in DMSO with final concentration of $50 \mathrm{mM}$ for in vivo experiments and $10 \mathrm{mM}$ for in vitro experiments.

\subsection{PCNA ubiquitination}

The PCNA loading and ubiquitination cascade was reconstituted in 96-well white roundbottom polypropylene plates (Greiner) in a buffer consisting of $40 \mathrm{mM}$ Tris-HCl, $\mathrm{pH} 7.5$, $8 \mathrm{mM} \mathrm{MgCl}_{2}$ and $10 \%$ glycerol with $2.5 \mathrm{nM}$ nicked circular pUC19, $50 \mathrm{nM} \mathrm{RFC}, 50 \mathrm{nM}$ Uba1, $250 \mathrm{nM}$ Rad6-Rad18 dimer, $50 \mathrm{nM}$ FLAG-PCNA and $250 \mathrm{nM}$ biotin-ubiquitin (final concentrations). Compounds were added to the samples, with pre-incubation for 
$15 \mathrm{~min}$ at $25^{\circ} \mathrm{C}$ before the addition of ATP to a final concentration of $2 \mathrm{mM}$ (to initiate the reaction cascade), followed by incubation for $2 \mathrm{~h}$ at $25^{\circ} \mathrm{C}$. The reactions were then terminated by the addition of EDTA to $20 \mathrm{mM}$ for Alpha assays or Laemmli sample buffer for western blot analyses or for silver staining. For Alpha assays, reaction mixtures were diluted 10x in buffer containing $20 \mu \mathrm{g} / \mathrm{ml}$ streptavidin-conjugated donor beads and antiFLAG antibody-conjugated acceptor beads in opaque white microplates under low-light conditions or green light, as recommended by the Alpha bead manufacturer, PerkinElmer. The plates were read on a Tecan Spark microplate reader at $23{ }^{\circ} \mathrm{C}$. For western blot analyses, FLAG-PCNA was detected with anti-FLAG antibody and quantitation from the western blot images were performed with the NIH Image J software (Schneider, Rasband, and Eliceiri 2012) and then analyzed with the GraphPad Prism software.

Note: The protein concentrations for the alpha based PCNA ubiquitination assay mentioned above were further optimized and miniaturized and are described in Results and Conclusions section.

\subsection{Uba1 Ubiquitin thioester assay}

$50 \mathrm{nM}$ FLAG-Ubal was charged with $150 \mathrm{nM}$ biotin-ubiquitin (150 nM Ubal and 450 $\mathrm{nM}$ biotin-ubiquitin for gel-based assay) in the presence of a buffer consisting of $40 \mathrm{mM}$ Tris- $\mathrm{HCl}, \mathrm{pH} 7.5,8 \mathrm{mM} \mathrm{MgCl} 2$ and $10 \%$ glycerol by adding $2 \mathrm{mM}$ ATP. The reaction was incubated for 30 minutes at $25{ }^{\circ} \mathrm{C}$. The reaction was stopped by adding $20 \mathrm{mM}$ of EDTA or Laemmli sample buffer for western blot analyses or silver staining, and 10 $\mu \mathrm{g} / \mathrm{ml}$ Acceptor and Donor beads in a buffer consisting of $25 \mathrm{mM}$ HEPES, $\mathrm{pH} 7.5,100$ $\mathrm{mM} \mathrm{NaCl}, 0.1 \%$ Tween 20 was added with $10 \mathrm{x}$ dilution. The reaction was incubated for $4 \mathrm{~h}$ at $25^{\circ} \mathrm{C}$. 


\subsection{Rad6-Ubiquitin thioester assay}

Variable concentrations of FLAG-Rad6, with biotin-ubiquitin held at $150 \mathrm{nM}$ and variable concentrations of biotin-ubiquitin, with FLAG-Rad6 held at $50 \mathrm{nM}$, were each separately varied while holding the other parameters under otherwise identical reaction and assay conditions in a buffer of $40 \mathrm{mM}$ Tris- $\mathrm{HCl}, \mathrm{pH} 7.5,8 \mathrm{mM} \mathrm{MgCl}_{2}$ and $10 \%$ glycerol. Ubal concentration was $50 \mathrm{nM}$ in these experiments. The reactions were initiated by the addition of $2 \mathrm{mM}$ ATP for a final volume of $20 \mu \mathrm{l}$, incubated for $30 \mathrm{~min}$ at $25^{\circ} \mathrm{C}$. The reaction was stopped by adding $20 \mathrm{mM}$ of EDTA and $10 \mu \mathrm{g} / \mathrm{ml}$ Acceptor and Donor beads in a buffer consisting of $25 \mathrm{mM}$ HEPES, pH 7.5, $100 \mathrm{mM} \mathrm{NaCl}, 0.1 \%$ Tween 20 was added with $10 \mathrm{x}$ dilution. The reaction was incubated for $4 \mathrm{~h}$ at $25{ }^{\circ} \mathrm{C}$.

Once satisfactory starting conditions were found, the overall reaction was conducted in two separate steps, which allows screening for direct inhibitors of Rad6 ubiquitin thioester formation whose mechanism is not just secondary to inhibition of Ubal ubiquitin thioester formation. For initial pre-charging of Ubal with biotinubiquitin, $100 \mathrm{nM}$ His-Ubal was combined with $300 \mathrm{nM}$ biotin-ubiquitin, with the reaction initiated by the addition of ATP to $2 \mathrm{mM}$, followed by incubation for $30 \mathrm{~min}$ at $25^{\circ} \mathrm{C}$. The reaction sample was then combined with an equal volume of $100 \mathrm{nM}$ FLAGRad6 (which can be pre-incubated with compounds for screening for direct Rad6 inhibitors), for final concentrations of $50 \mathrm{nM}$ His-Uba1, $150 \mathrm{nM}$ biotin-ubiquitin and 50 nM FLAG-Rad6. The mixture was incubated for another $10 \mathrm{~min}$ at $25{ }^{\circ} \mathrm{C}$, with the remaining procedures as before.

\subsection{Rad6-Rad18 interaction assay}

$25 \mathrm{nM}$ FLAG-Rad6 and $25 \mathrm{nM}$ His-Rad18 (equimolar) concentrations tested in $2 \mathrm{x}$ increments under otherwise identical reaction and assay conditions in a buffer of $40 \mathrm{mM}$ 
Tris- $\mathrm{HCl}$, pH 7.5, $8 \mathrm{mM} \mathrm{MgCl} 2$ and $10 \%$ glycerol. The reaction was incubated at $25{ }^{\circ} \mathrm{C}$ for $30 \mathrm{~min}$, then diluted by a factor of $10 \times$ in a buffer consisting of $25 \mathrm{mM}$ HEPES, $\mathrm{pH}$ 7.5, $100 \mathrm{mM} \mathrm{NaCl}, 0.1 \%$ Tween 20 and $20 \mathrm{mM}$ EDTA with donor and acceptor beads at $10 \mu \mathrm{g} / \mathrm{ml}$. After $2 \mathrm{~h}$ of incubation at $25^{\circ} \mathrm{C}$ in the dark, the plates were read on the Tecan plate reader at $23^{\circ} \mathrm{C}$.

\subsection{Alpha assay for Rad18 auto-ubiquitination}

FLAG-Rad18 and biotin-ubiquitin concentrations were separately varied under otherwise identical reaction and assay conditions in a buffer of $40 \mathrm{mM}$ Tris- $\mathrm{HCl}, \mathrm{pH} \mathrm{7.5,8 \textrm {mM }}$ $\mathrm{MgCl}_{2}$ and $10 \%$ glycerol. Uba1 was held constant at $50 \mathrm{nM}$ and Rad6-Rad18 dimer at $100 \mathrm{nM}$. The reaction was incubated at $25^{\circ} \mathrm{C}$ for $1 \mathrm{~h}$, then terminated and diluted by a factor of $10 \times$ in a buffer consisting of $25 \mathrm{mM}$ HEPES, $\mathrm{pH} 7.5,100 \mathrm{mM} \mathrm{NaCl}, 0.1 \%$ Tween 20 and $20 \mathrm{mM}$ EDTA and $1 \mathrm{mM}$ freshly added DTT, with donor and acceptor beads at $10 \mu \mathrm{g} / \mathrm{ml}$. After $4 \mathrm{~h}$ of incubation at $25^{\circ} \mathrm{C}$ in the dark, the plates were read on the Tecan plate reader at $23^{\circ} \mathrm{C}$.

\subsection{NMR analysis}

NMR spectra were acquired with a Bruker Avance $600 \mathrm{MHz}$ spectrometer equipped with a $5 \mathrm{~mm}$ z-gradient CP-TCI triple-resonance cryoprobe at $303 \mathrm{~K}$. EGCG and Uba1 were dissolved in $20 \mathrm{mM}$ phosphate-buffered saline at $\mathrm{pH} 7.4\left(90 \% \mathrm{H}_{2} \mathrm{O}, 10 \% \mathrm{D}_{2} \mathrm{O}\right)$, containing $150 \mathrm{mM} \mathrm{NaCl}$ and $0.02 \% \mathrm{NaN}_{3}$. To prevent EGCG oxidation, $1 \mathrm{mM}$ tris (2carboxyethyl)phosphine was added to the solutions. EGCG and Ubal concentrations were $400 \mu \mathrm{M}$ and $4 \mu \mathrm{M}$, respectively. All the spectra were acquired with excitation sculpting solvent suppression pulse scheme. In STD experiments, 40 equally spaced $50 \mathrm{~ms}$ Gaussian-shaped pulses were used for the selective saturation of the protein, thus, the total saturation time was $2 \mathrm{~s}$. The on-resonance irradiation and the off-resonance saturation 
frequencies were set at $0.86 \mathrm{ppm}$ and $40.0 \mathrm{ppm}$, respectively. A total of $2 \mathrm{k}$ scans were collected for each pseudo-2D experiment. 2D NOESY experiments were acquired with 128 increments and a mixing time of $100 \mathrm{~ms}$. As a control, all the experiments were repeated for a sample containing EGCG at the same concentration but in the absence of the protein.

\subsection{Cell culture}

For cellular experiments, HEK 293FT cells (a fast-growing SV40 large T antigentransformed strain of HEK 293 cells designed for enhanced transgene expression in transient transfections) were grown in growth medium consisting of Dulbecco's modified Eagle's medium (DMEM; Sigma-Aldrich) supplemented with $10 \%$ fetal bovine serum (FBS; Gibco) in a humidified cell culture incubator at $37^{\circ} \mathrm{C}$ with $5 \% \mathrm{CO}_{2}$.

\subsection{Cell survival assay}

HEK 293FT cells were evaluated for survival following compound treatments by the Alamar Blue (resazurin) assay. Cells were plated onto 96-well plates at $4.8 \times$ $10^{4}$ cells/well in $0.5 \%$ FBS-containing DMEM at $37^{\circ} \mathrm{C}$ and $5 \% \mathrm{CO}_{2}$. After $24 \mathrm{~h}$, compounds were added. After $24 \mathrm{~h}$ of treatment, resazurin was added to a final concentration of $0.12 \mathrm{mM}$. Following $4 \mathrm{~h}$ of incubation, conversion to the resorufin product was measured (with excitation at $542 \mathrm{~nm}$ and emission at $590 \mathrm{~nm}$ ) on a fluorescence plate reader. 


\subsection{Cell transfections}

HEK 293FT cells $\left(1.5 \times 10^{6}\right)$ were plated onto $6-\mathrm{cm}$ plates in $5 \mathrm{ml}$ of DMEM with $10 \%$ FBS and allowed to grow for $24 \mathrm{~h}$ at $37^{\circ} \mathrm{C}$ and $5 \% \mathrm{CO}_{2}$. For transfections, $6 \mu \mathrm{g}$ of plasmid DNA (an empty vector containing FLAG-tag sequence only, FLAG-Uba1, or FLAGubiquitin) and $10 \mu \mathrm{l}$ of Lipofectamine 2000 were used for each plate. The DNA and the reagent were diluted separately in $500 \mu \mathrm{l}$ of Opti-MEM (Gibco) and each was mixed by vortexing. After $5 \mathrm{~min}$ of incubation, the two tubes were combined and incubated for another $20 \mathrm{~min}$. Prior to the addition of the transfection solution to the cells, the medium was replaced with $4 \mathrm{ml}$ of Opti-MEM. The transfection solution was then added dropwise. After $3 \mathrm{~h}$ of incubation, the medium was changed to $0.5 \%$ FBS-containing DMEM and the cells were plated for cell survival experiments, as above

\subsection{Cellular ubiquitination}

HEK 293FT cells were plated in 6-well plates at $8 \times 10^{5}$ cells/well in DMEM with $0.5 \%$ FBS. After $24 \mathrm{~h}$ at $37^{\circ} \mathrm{C}$ and $5 \% \mathrm{CO}_{2}$, EGCG was added; then 30 min later, MG132 was added to a concentration of $50 \mu \mathrm{M}$, with incubation for another $30 \mathrm{~min}$ (for a total of 1 -h EGCG treatment). Cells were harvested and whole-cell lysates were prepared in RIPA lysis buffer containing protease inhibitor cocktail (SIGMAFAST from Sigma-Aldrich) and sonicated. Equivalent loadings of total proteins for each treatment, as determined by Bradford assay of each extracted sample, were subjected to electrophoresis on $8 \%$ SDSpolyacrylamide gels and western blot analysis, probed with anti-ubiquitin antibody, then stripped and reprobed with an anti- $\beta$-tubulin antibody.

\subsection{Statistical analysis}

In a high-throughput assay (HTS) large chemical library was screened, hits were identified on the basis on following statistical parameters: 
Signal-to-noise $(\mathbf{S} / \mathbf{N})$ ratio is an indication of the degree of confidence with which signal can be regarded as real. In addition to S/N Signal-to-background (S/B) ratio is also considered. The $\mathrm{S} / \mathrm{N}$ ratio is not sufficient to decide whether the assay is good.

$$
\begin{aligned}
& \mathrm{S} / \mathrm{N}=\frac{\text { mean signal-mean background }}{\text { standard deviation of background }} \\
& \mathrm{S} / \mathrm{B}=\frac{\text { mean signal }}{\text { mean background }}
\end{aligned}
$$

The inherent problem of considering $\mathrm{S} / \mathrm{N}$ and $\mathrm{S} / \mathrm{B}$ cannot define the level of variability. Hence in these scenarios, $\mathbf{z}$-factor is considered. The z-factor is defined in terms of four parameters: the means and standard deviation of both the positive and negative controls. Given these values, the Z-factor is defined as:

$$
\mathrm{Z}=1-\frac{3 \mathrm{SD} \text { of sample }+3 \mathrm{SD} \text { of control }}{\mid \text { mean of sample }- \text { mean of control } \mid}
$$

Z-factor is sensitive to outliers, a variation is known as the robust $\mathrm{z}$-score, which substitutes the outlier-insensitive median and median absolute deviation (MAD) for mean and standard deviation in the z-score calculation, is generally considered preferable for HTS. We considered z-prime and z-robust both for hit selection in our screening (J. H. Zhang, Chung, and Oldenburg 1999; N., C., and Che 2013).

Another measurement taken for quality control and hit selection is considering strictly standardized mean difference (SSMD) and Signal window values. SSMD is the mean divided by the standard deviation of the difference between two random groups. Signal window values, this is a more indicative measure of the data range in an HTS assay than 
the above parameters. Two alternative versions of the SW are presented below (N., C., and Che 2013).

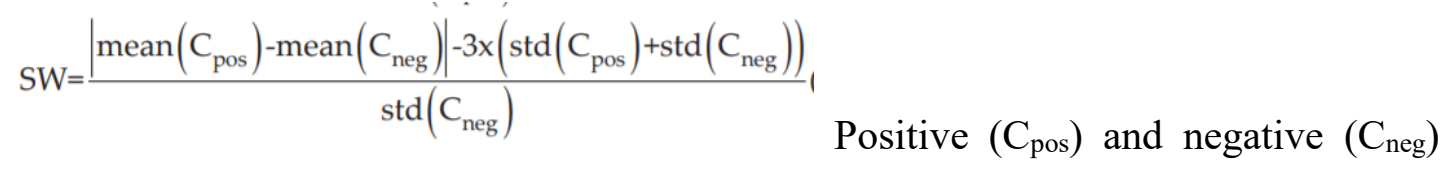

controls

Half-maximal inhibitory concentration IC $_{50}$ is a measure of the effectiveness of a substance in inhibiting a specific biological or biochemical function.

To calculate $\mathrm{S} / \mathrm{N}, \mathrm{S} / \mathrm{B}, \mathrm{SSMD}, \mathrm{Z}$ factor and signal to window values an excel sheet template was prepared which automatically calculated these values. All the Curve fitting, $\mathrm{IC}_{50}$ calculations were carried out using the GraphPad Prism 8.0-8.2 software. 


\section{Results and Conclusions}

\subsection{Development of a high-throughput screening assay to discover modulators of PCNA ubiquitination}

To discover small-molecule inhibitor for PCNA ubiquitination, we adapted amplified luminescent proximity homogeneous assay (Alpha) technology for assay development for PCNA ubiquitination. The assay consists of a reconstituted system with biotin-ubiquitin, hUba1, FLAG-tagged PCNA, RFC, Rad6-Rad18 dimer and nicked circular pUC19 plasmid (Lajos Haracska et al. 2006). We have developed a quantitative assay for PCNA ubiquitination based on a PerkinElmers Alphascreen/AlphaLisa system (Figure 7a), with a wide dynamic range and high signals in the positive control (with ATP) relative to the negative control (without ATP). We have also confirmed it by Western blot analysis (Figure 7b). The PCNA undergoes monoubiquitination at Lys164 residue, we found monoubiquitination of PCNA at K164 residue, as the K164 mutant did not show ubiquitination (Lajos Haracska et al. 2006; Unk et al. 2008). 

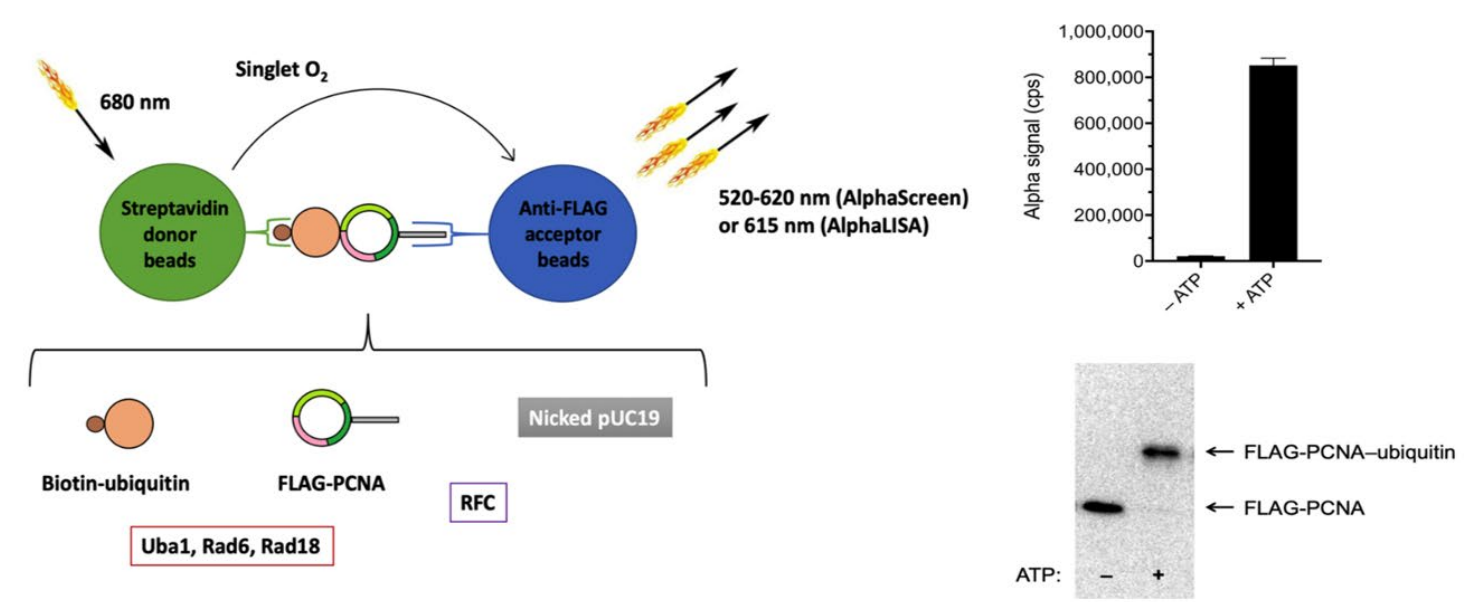

Figure 7. Reconstituted assay for PCNA ubiquitination. a. High-throughput screening system for in vitro PCNA ubiquitination, based on AlphaScreen/AlphaLISA technology. Note: Unlike in this simplified diagram, each of the three subunits of the PCNA trimer bears a FLAG tag and each PCNA molecule is monoubiquitinated on K164 at saturation in the reaction; thus, higher bead-to-trimer stoichiometry will occur than indicated (in principle, three donor and three acceptor beads per complex, depending on steric factors). b. Upper panel: Quantitative measurement of PCNA ubiquitination by the Alpha system for non-initiated (-ATP) and initiated (+ATP) ubiquitination reaction cascades. Data represent mean and standard deviation (SD) for six independent experiments for Alpha signal values in counts per second (cps) following incubation without or with ATP for $2 \mathrm{~h}$, under conditions described in Materials and Methods. Lower panel: Representative western blot of samples incubated without or with ATP for $2 \mathrm{~h}$ probed with anti-FLAG antibody, as described in Materials and Methods, showing nonubiquitinated FLAG-PCNA (lower band) and ubiquitinated FLAG-PCNA (upper band).

\subsection{Optimization of the PCNA-ubiquitination-based Alpha assay}

Initially, we developed the Alpha assay with the protein concentrations described in the Materials and Methods section, so that we can compare the efficacy of PCNA ubiquitination in alpha assay with western blot analysis. Starting from the conditions we optimized for Western blot analysis and initial PCNA ubiquitination alpha assay, we further refined the reconstituted system for more sensitive Alpha technology to reduce the consumption of various resources. The overall Alpha assay can be viewed as composed of two main parts: first, the biochemical PCNA ubiquitination reaction that generates the proximity relationship to be assayed; second, the procedures for Alpha detection, which 
involves dilution of the initial samples with the addition of beads and then the actual detection itself. Both of these major steps of the overall assay were pursued for optimization. We started the optimization by titrating the concentrations of the biotinubiquitin, FLAG-PCNA, RFC, Uba1 and Rad6-Rad18 dimer. We titrated the individual protein in each experiment by keeping other components of the PCNA ubiquitination reaction constant (Figure 8). DNA can also be the target for many small molecules, to make assay more sensitive we also titrated pUC19 concentration by keeping other components constant as described previously (Figure 9). Based on the experiments (Figures 8 and 9), we chose 10 nM RFC, 10 nM Uba1, 100 nM Rad6-Rad18 dimer, 50 nM FLAG-PCNA, $250 \mathrm{nM}$ biotin-ubiquitin and $2 \mathrm{nM}$ pUC19 as optimal concentrations. The experiments performed afterward thus conducted with these concentrations. After the optimization of proteins and DNA, PCNA ubiquitination reaction kinetics was performed (Figure 10) and we found $2 \mathrm{~h}$ incubation gives the best signal range.

To find out whether we can miniaturize the PCNA ubiquitination reaction volumes, we performed PCNA ubiquitination reactions in $5 \mu \mathrm{L}, 10 \mu \mathrm{L}$ and $20 \mu \mathrm{L}$ (Figure $\mathrm{S} 1$ ). We found out that a $20 \mu \mathrm{L}$ reaction gives the best signal range. We also tested donor and acceptor bead incubation times for the detection of ubiquitinated PCNA and we found out that $4 \mathrm{~h}$ works the best (Figure S2). After completion of the PCNA ubiquitination reaction, alpha beads are added which dilutes the reaction. We tested dilution factors for the detection of ubiquitinated PCNA in the alpha assay and we found out 10x dilution gives the best signals (Figure S3). The donor and acceptor bead concentrations, donor and acceptor bead ratios and donor/acceptor beads order of addition experiments were performed to detect the best alpha signal range for the detection of ubiquitinated PCNA (Figure S4, S5 and S6) and we found out that $10 \mu \mathrm{g} / \mathrm{ml}$ beads concentration, an equimolar ratio of beads (i.e. $10 \mu \mathrm{g} / \mathrm{ml}$ each) and addition of donor and acceptor beads at the same 
time gives the best signal range. In the end, we sought to answer other questions such as tolerance of DMSO and ATP concentration (Figure S7 and S8).

a

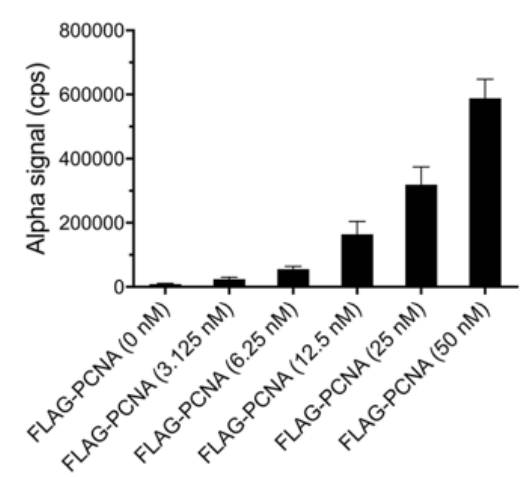

C

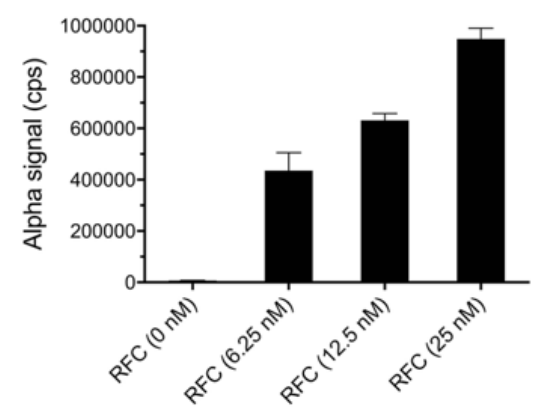

d

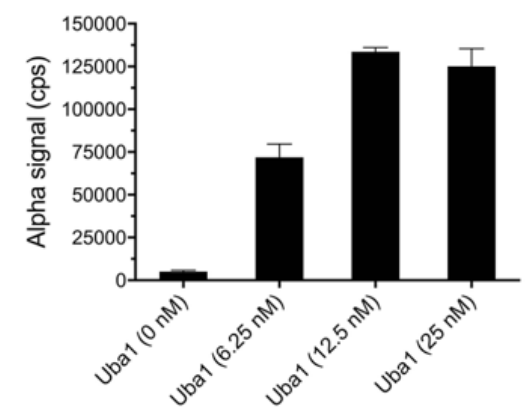

b

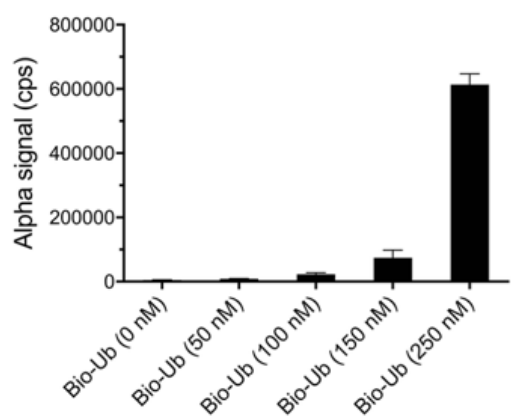

C bis

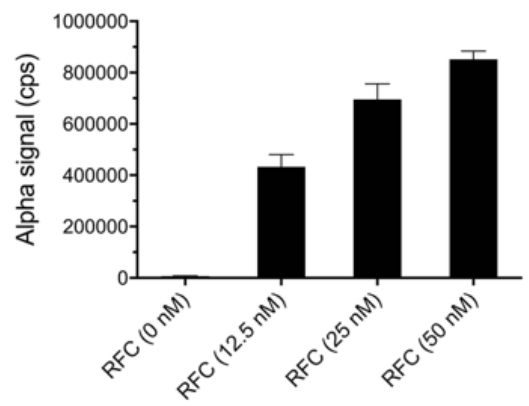

e

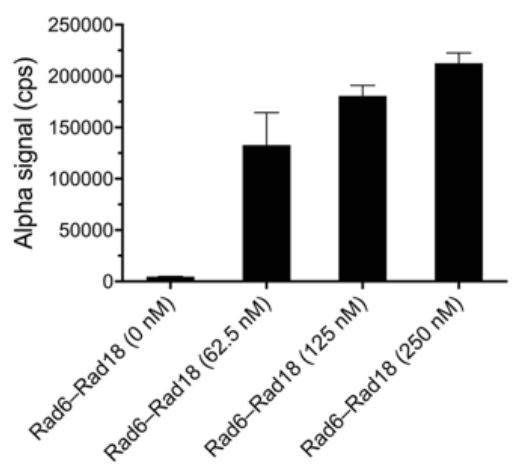

Figure 8. Optimization of protein components in the Alpha assay for PCNA ubiquitination. a FLAG-PCNA, b biotin-ubiquitin (Bio-Ub), c RFC (left and right panels are different concentrations range from separate experiments), d Uba1 and e Rad6-Rad18 dimer, with other components in each case held constant as noted in Materials and Methods. 


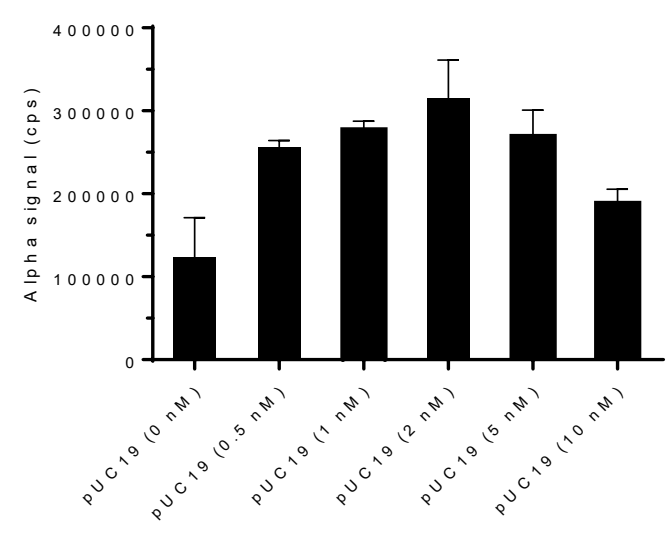

Figure 9. Nicked pUC19 plasmid concentration variation in the PCNA ubiquitination assay. Different nicked pUC19 plasmid concentrations of $0 \mathrm{nM}, 0.5 \mathrm{nM}, 1 \mathrm{nM}, 2 \mathrm{nM}, 5$ $\mathrm{nM}$ and $10 \mathrm{nM}$ were tested, with the other reaction components held constant as described in Materials and Methods, with the alpha assay carried out otherwise as described in the Materials and Methods section.

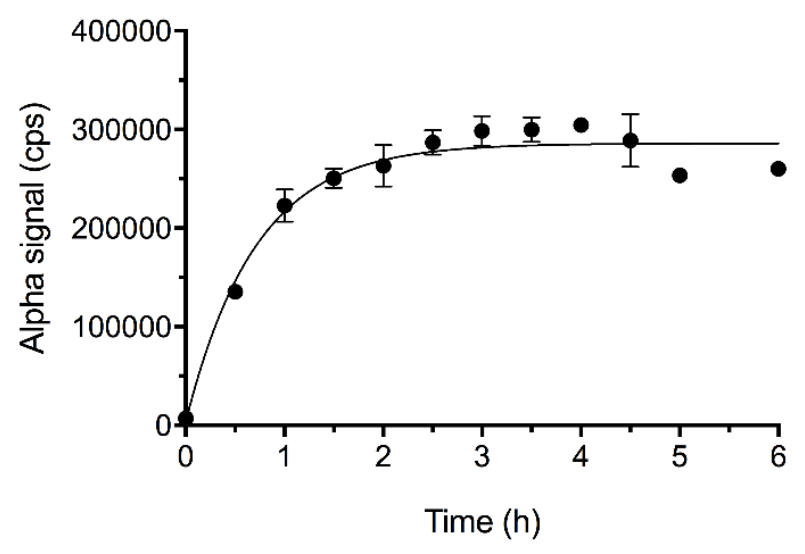

Figure 10. PCNA ubiquitination reaction kinetics under final optimized conditions. The reaction with optimized conditions based on Figure 8 and 9 was stopped at different time intervals from 0 to $6 \mathrm{~h}$ by adding $20 \mathrm{mM}$ EDTA, followed by alpha assay carried out otherwise as described in the Materials and Methods section.

\subsection{Final optimized conditions for the high-throughput Alpha assay for PCNA ubiquitination}

Based on the sum of all the optimized experiments for both the PCNA ubiquitination reaction and the Alpha detection step of the overall assay, the final conditions were chosen to balance both optimal assaying and material usage concerns for the PCNA 
ubiquitination assay. The final PCNA ubiquitination reaction with $10 \mathrm{nM}$ RFC, $10 \mathrm{nM}$ Uba1, 100 nM Rad6-Rad18 dimer, 50 nM FLAG-PCNA, 250 nM biotin-ubiquitin and 2 nM nicked pUC19 was initiated by addition of $2 \mathrm{mM}$ ATP in a reaction volume of $20 \mu \mathrm{l}$ in 96-well plates. The reaction was incubated for $2 \mathrm{~h}$ at $25^{\circ} \mathrm{C}$ and after that diluted by a factor of $10 \times$ in Alpha buffer containing donor and acceptor beads $(10 \mu \mathrm{g} / \mathrm{ml}$ each) and $20 \mathrm{mM}$ EDTA, with incubation of $4 \mathrm{~h}$ in the dark at $25^{\circ} \mathrm{C}$, followed by the Alpha detection. We found that $\mathrm{Z}$ factors had typical values for any given plate between 0.6 and 0.9 , particularly by robust statistics, which is less sensitive to outliers than standard statistics, when comparing positive (with ATP) and negative (without ATP) control values, indicating suitability for high-throughput screening. Per plate, strictly standardized mean difference (SSMD) values, signal-to-noise ratios, signal-tobackground ratios and signal window values were generally also good. The alpha assay sensitivity was also tested by using the PCNA ubiquitination reaction at scaling factors of $0.25 \times, 0.5 \times, 1 \times, 2 \times, 4 \times$ and $8 \times$ for the optimized concentrations of all proteins and DNA (where $1 \times$ represents the optimized concentrations) for alpha assay (Figure 11).

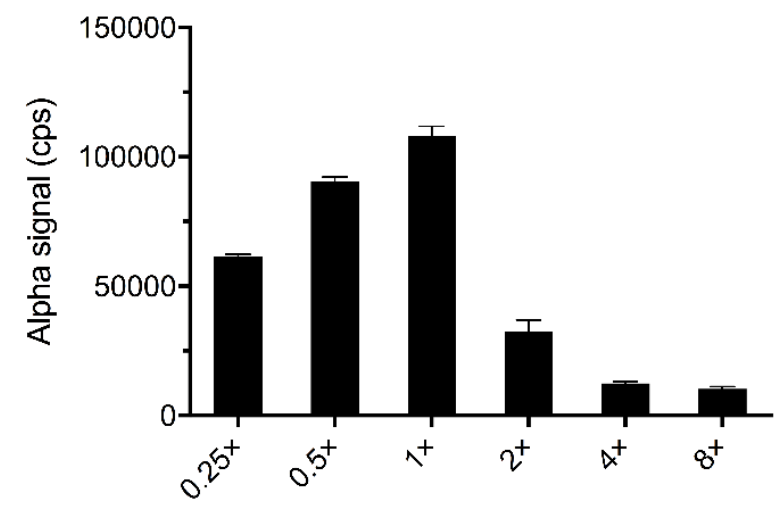

Figure 11. Representative graph of the sensitivity of the Alpha assay for the detection of ubiquitinated PCNA. Reactions were conducted at scaling factors of $0.25 \times$, $0.5 \times, 1 \times, 2 \times, 4 \times$ and $8 \times$ for the optimized concentrations of all proteins and DNA (where $1 \times$ represents the optimized concentrations). The PCNA ubiquitination cascade was initiated by the addition of ATP to $2 \mathrm{mM}$, with subsequent incubation for $2 \mathrm{~h}$ at $25^{\circ} \mathrm{C}$ and termination by the addition of EDTA to $20 \mathrm{mM}$ and followed by an optimized Alpha assay (as optimized above). 


\subsection{EGCG inhibits PCNA ubiquitination}

We have screened a chemical library from Avicor Ltd from which we have identified EGCG as a potential bioactive hit that inhibits PCNA ubiquitination (PCNA ubiquitination was the first alpha assay that we developed on a demo instrument from which we discovered EGCG. Later we characterized EGCG and its 11 analogs in a gelbased assay because the demo instrument was gone and we were waiting for the Tecan Spark Alpha scanner. Once, we received the alpha reader the re-optimization and miniaturization of the alpha assay were performed followed by the validation of EGCG and its analogs for the IC50 on it, see in Supplementary Table 3). The confirmation of EGCG's inhibitory activity by the western blot probed with anti-FLAG antibody. The Western blot showing the dose-response for inhibition of PCNA ubiquitination by EGCG (0.0122 to $6.25 \mu \mathrm{M}$ in concentration increments of $2 \times)$, with a final DMSO carrier solvent concentration of $2 \%$ in all cases. Samples were pre-incubated with EGCG for $15 \mathrm{~min}$ before the addition of ATP, then further incubated for $2 \mathrm{~h}$. Negative and positive controls consisted of parallel samples incubated with DMSO alone in the absence (-) or presence $(+)$ of ATP, respectively (Figure 12).

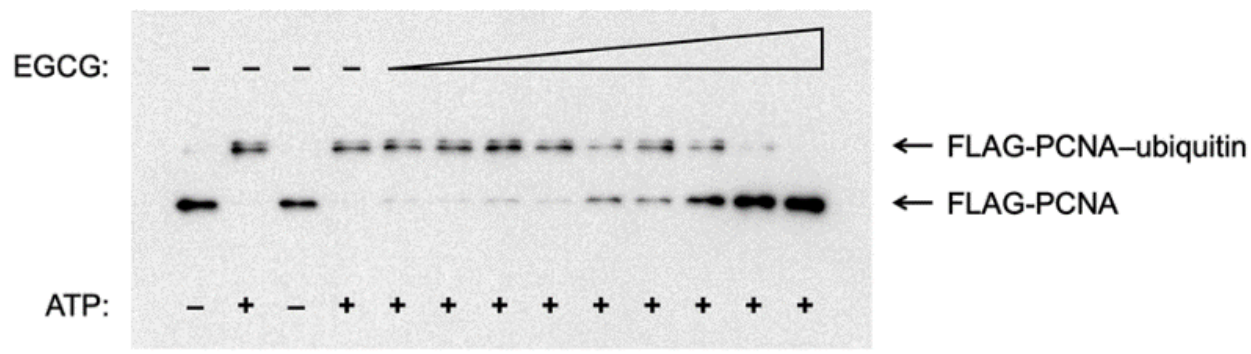

Figure 12. Western blot analysis showing dose-response for EGCG in PCNA ubiquitination. Representative dose-response western blot probed with anti-FLAG antibody showing the inhibition of PCNA ubiquitination by EGCG $(0.0122$ to $6.25 \mu \mathrm{M}$ in concentration increments of $2 \times$ ). 


\subsection{Dose-response analysis for different compounds in PCNA ubiquitination}

The dose-response experiments were performed with EGCG and its analogs using western blot analysis. The relative percentage of PCNA ubiquitination in a western blot was calculated according to (FLAG-PCNA-ubiquitin)/ (FLAG-PCNA + FLAG-PCNAubiquitin) $\times 100 \%$ for each lane internally from different independent experiments, as indicated for each case (Figure 14 and also in Supplementary Table 2 along with $\mathrm{IC}_{50}$ values). Dose-response experiments revealed that EGCG inhibits PCNA ubiquitination with a half-maximal inhibitory concentration $\left(\mathrm{IC}_{50}\right)$ of $228 \mathrm{nM}$.

We considered $500 \mu \mathrm{M}$ with DMSO concentration of $2 \%$, as a threshold and compounds which did not show inhibition at this dose were concluded as inactive (see figure 13). The negative and positive controls consisted of $2 \%$ DMSO alone without or with ATP, respectively.

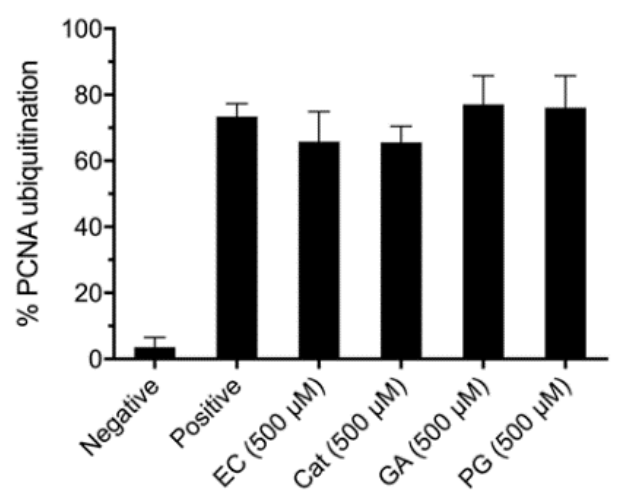

Figure 13. Compounds showing no inhibitory activity in the PCNA ubiquitination assay at $500 \mu \mathrm{M}$, with a DMSO concentration of $2 \%$ in all cases. Data represent mean $\pm \mathrm{SD}$, derived from the quantitation of western blot images 

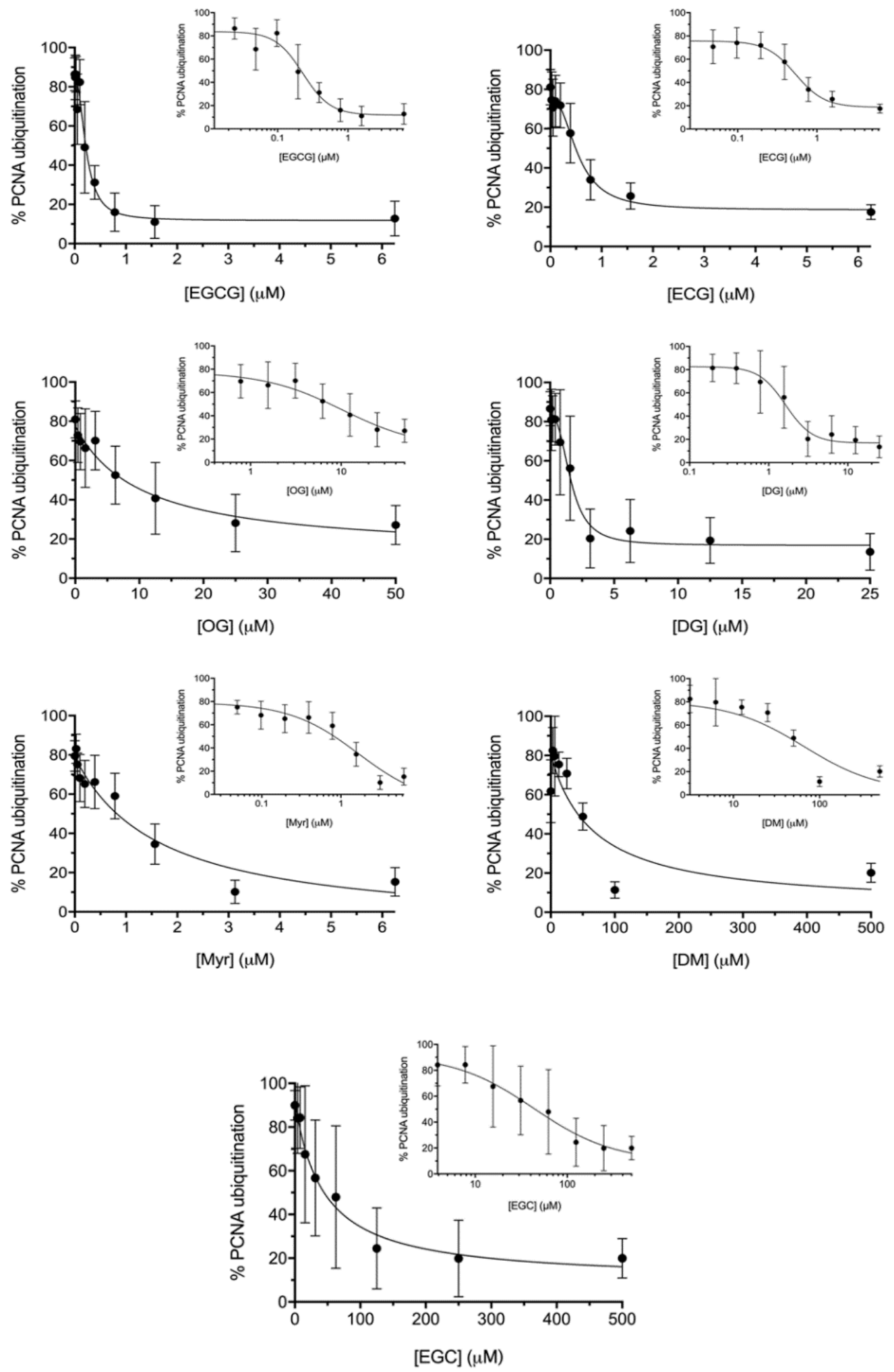

Figure 14. Dose-response curves for the percentage of PCNA ubiquitination inhibition by EGCG and its analogs. The dose-response curves are plotted both linearly and semilogarithmically (inset), with a DMSO concentration of $2 \%$ in all cases. Data represent mean \pm SD from 3-7 independent experiments, derived from the quantitation of western blot images. 


\subsection{EGCG blocks Uba1-ubiquitin thioester formation}

In an attempt to identify target proteins involved in the ubiquitination pathway, we investigated each small step involved in ubiquitination to identify target proteins involved in the reaction. We, therefore, looked at a specific step in the ubiquitination cascade and found that EGCG directly inhibits the formation of Uba1-ubiquitin thioester formation by directly targeting the Uba1 protein. To specifically identify whether it targets ubiquitin or Ubal in the thioester assay, we carried out thioester experiments by the pre-incubation of either Uba1 or ubiquitin with EGCG and Myr, respectively. The pre-incubation of Uba1 alone with EGCG prior to the addition of ubiquitin and ATP leads to absolute inhibition of the Uba1-ubiquitin thioester adduct, but not when pre-incubated with ubiquitin first (Figure 15). However, myricetin inhibits the formation of Uba1-ubiquitin thioester adduct in both cases, irrespective of pre-incubation with either of the proteins (Figure 15). Final compound concentrations were $10 \mu \mathrm{M}$ for EGCG or $50 \mu \mathrm{M}$ for Myr (with DMSO alone as control and a DMSO concentration of $2 \%$ in all cases). Following pre-incubation, reactions were allowed to proceed for $2 \mathrm{~h}$ with ubiquitin, Ubal and ATP. A comparison of results in the absence or presence of DTT as a reducing agent confirms that the conjugation is through the reducible thioester.

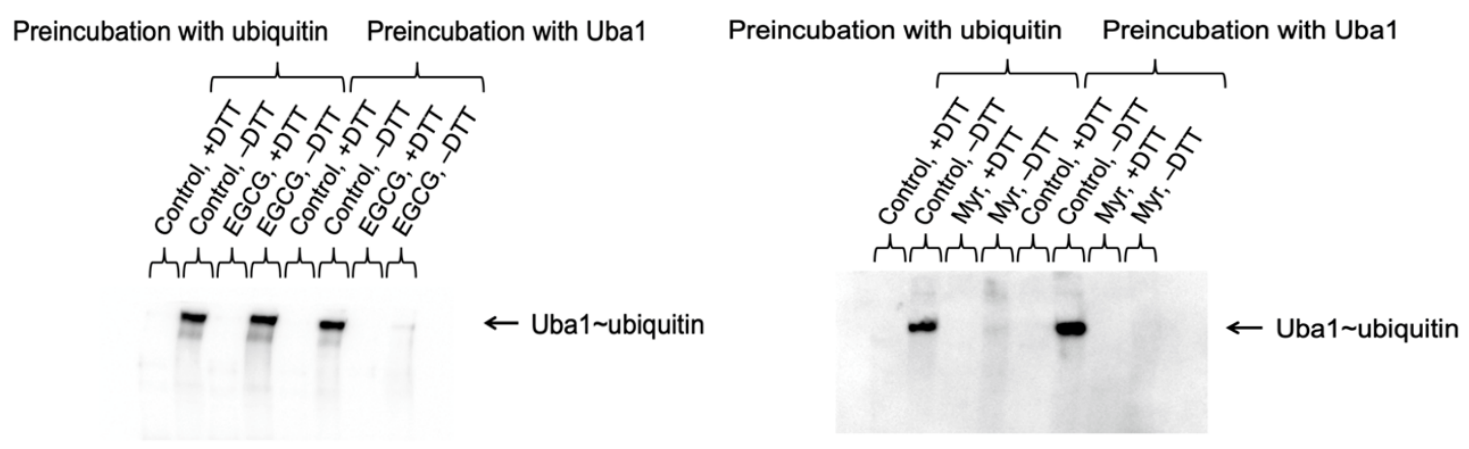

Figure 15. The effects of EGCG and Myr on Ubal and ubiquitination are reversible. Representative western blots showing that EGCG inhibits Ubal ubiquitin thioester formation when pre-incubated with Ubal before adding ubiquitin, but not when preincubated with ubiquitin first, while Myr inhibits Ubal ubiquitin thioester in both cases. 


\subsection{Effects of EGCG and myricetin on Uba1 are reversible}

We conducted reversibility experiments by preincubating Uba1 or ubiquitin with EGCG and then washing out unbound compound by serial centrifugal filtration, followed by addition of other components to assay for ubiquitination. We found that ubiquitination activity recovers upon washout of compound, demonstrating that EGCG inhibits Ubal and consequent ubiquitination in a reversible manner (Figure 16).

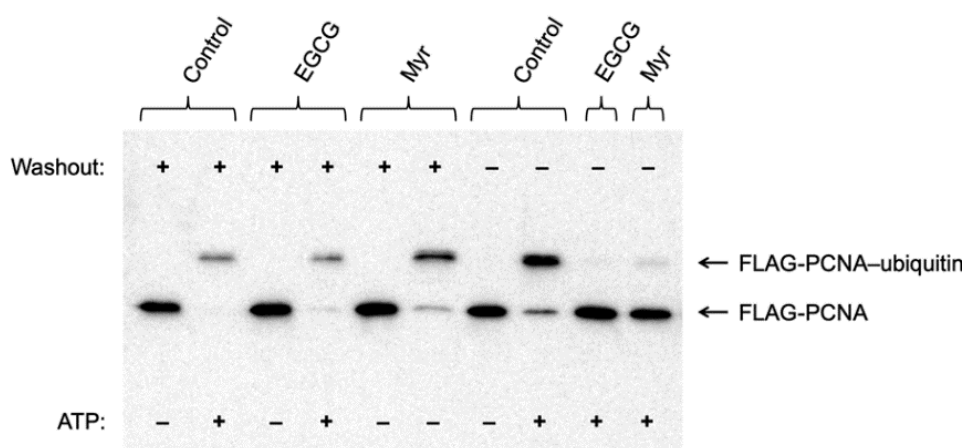

Figure 16. The effects of EGCG and Myr on Ubal and ubiquitination are reversible. $30 \mu \mathrm{M}$ EGCG and $30 \mu \mathrm{M}$ Myr (with DMSO alone as control and a DMSO concentration of $2 \%$ in all cases) were preincubated with Ubal for $2 \mathrm{~h}$, completely washed out by serial centrifugal filtration, and then assayed for PCNA ubiquitination activity after addition of other reaction components, with detection by Western blot analysis with anti-FLAG antibody.

\subsection{Dose-response analysis for Uba1 ubiquitin thioester formation}

The dose-response for the relative percentage of Uba1 ubiquitin thioester formation with increasing concentrations of each compound was calculated by SDS PAGE gel silver staining (Figure 18). Each value was normalized on a gel-by-gel basis to the parallel positive control (DMSO alone with ATP) level of Uba1 ubiquitin thioester conjugate formed in each case and from the quantitation of silver-stained SDS-polyacrylamide gels of reaction samples without DTT. The compounds with no inhibitory activity at $500 \mu \mathrm{M}$ with a DMSO concentration of 2\% in all cases in the gel-based assay are shown in Figure 
17. The calculated $\mathrm{IC}_{50}$ of EGCG is $1.6 \mu \mathrm{M}$ and other $\mathrm{IC}_{50}$ values are summarized in Supplementary Table 2.

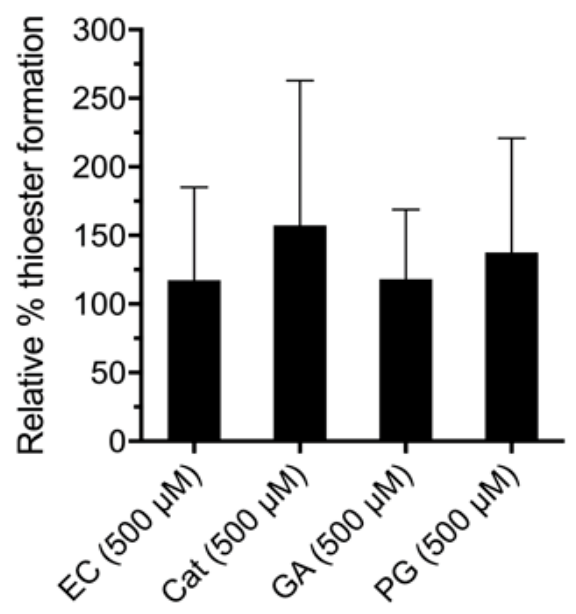

Figure 17. Compounds showing no inhibitory activity in Uba1 ubiquitin thioester formation at $500 \mu \mathrm{M}$ in the gel-based assay. The DMSO concentration was $2 \%$ in all cases. Data represent mean $\pm \mathrm{SD}$, derived from quantitation of silver-stained gel images. 

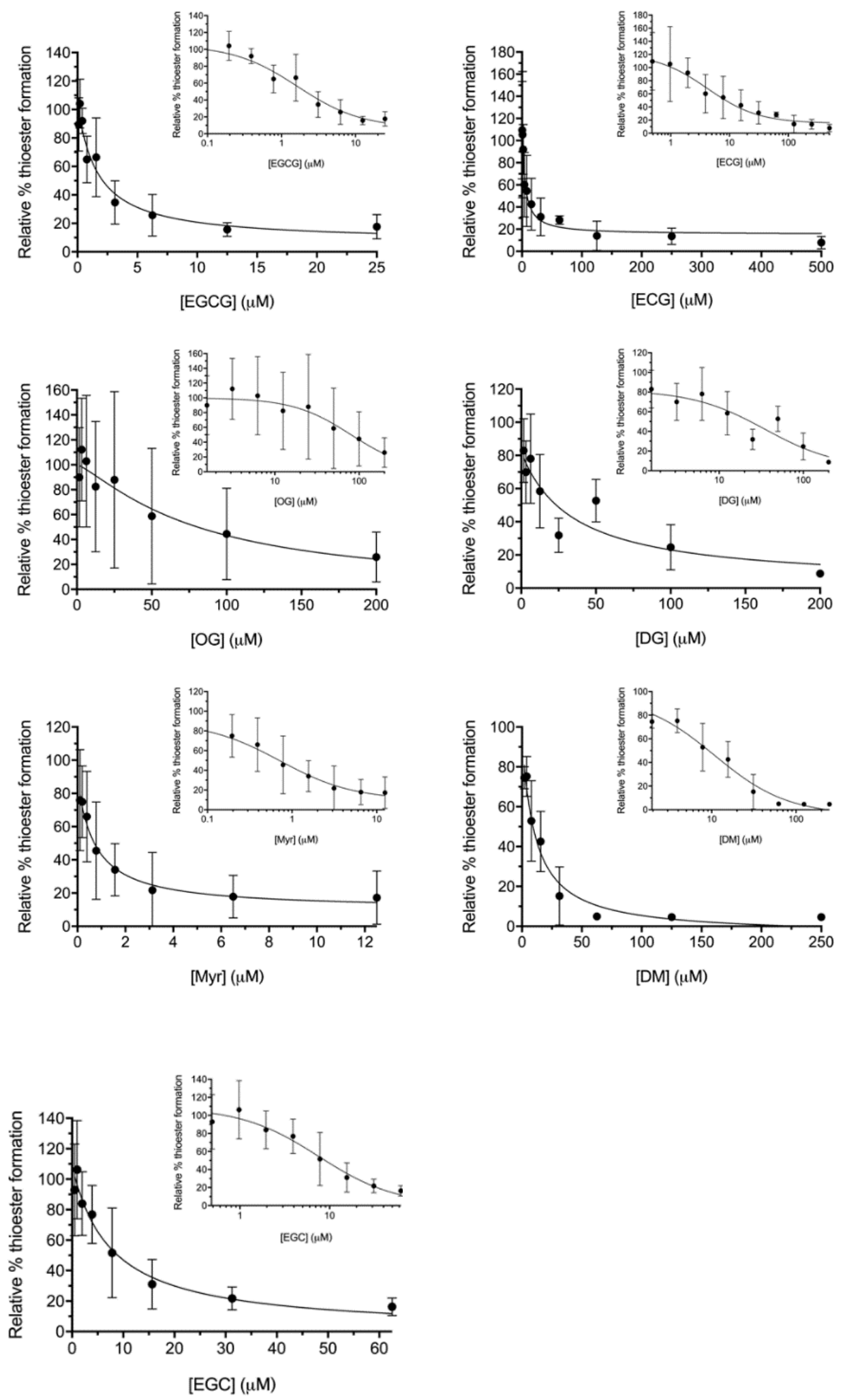

Figure 18. Dose-response for EGCG and its analogs in Ubal ubiquitin thioester formation. The dose-response curves are plotted both linearly and semi-logarithmically (inset), with a DMSO concentration of $2 \%$ in all cases. Data represent mean $\pm \mathrm{SD}$ for 34 independent experiments, derived from the quantitation of silver-stained gel images. 


\subsection{Nuclear magnetic resonance (NMR) shows that EGCG binds Uba1}

The binding of EGCG to Ubal was elucidated by ligand-detected ${ }^{1} \mathrm{H}$ NMR techniques. In the presence of Uba1, signal intensity loss was observed in the aromatic ${ }^{1} \mathrm{H}$ NMR signals of EGCG compared with the control spectrum containing no protein (Figure 19a), which can be indicative the dissociation constant $\left(\mathrm{K}_{\mathrm{d}}\right)$ of the binding is in low micromolar. The interaction was also tested by standard saturation transfer difference (STD) NMR (M. Mayer and Meyer 2001; Moriz Mayer and Meyer 1999; Meyer and Peters 2003; Becker et al. 2018) and transferred NOE (trNOE) experiments. In the STD spectrum of EGCG, ${ }^{1} \mathrm{H}$ signals of EGCG could be clearly detected proving ligand binding to Uba1 (Figure 19b). The interaction could also be confirmed via trNOE NMR. In the presence of Uba1, positive cross-peaks were observed due to the higher cross-relaxation rates of EGCG upon protein binding (Figure 19c). In the 2D NOESY spectrum of the EGCG control sample, no cross-peaks appeared.

Both STD and trNOE requires dynamic equilibrium between the free and the bound states of the ligand and are sensitive in the $\mathrm{K}_{\mathrm{d}}$ range of $10^{-3}-10^{-8} \mathrm{M}$. As signal intensity loss of EGCG signals was also observed, the NMR measurements support that the dissociation constant of the EGCG - Uba1 interaction is in the high nanomolar - low micromolar range if a single binding mode is present. Considering the $\mathrm{IC}_{50}$ value of the biological response, NMR results strongly suggest that a direct EGCG-Uba1 binding is responsible for the activity. 
a

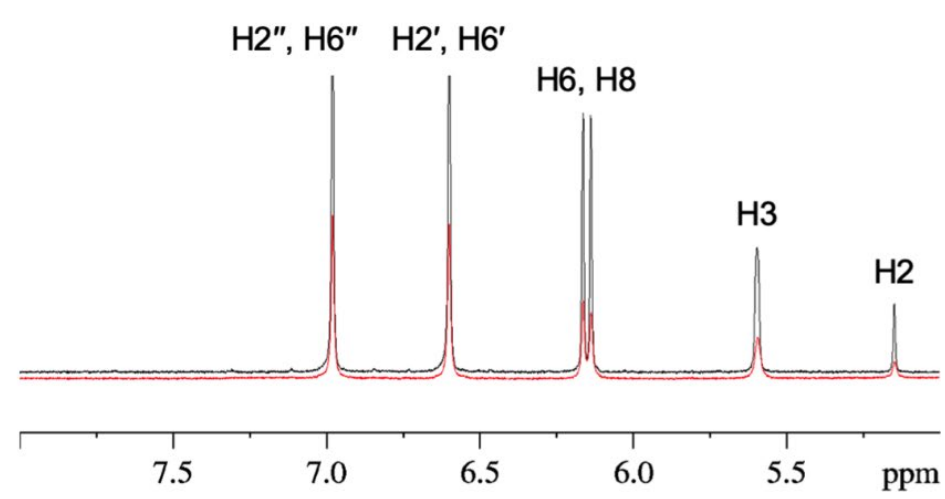

b

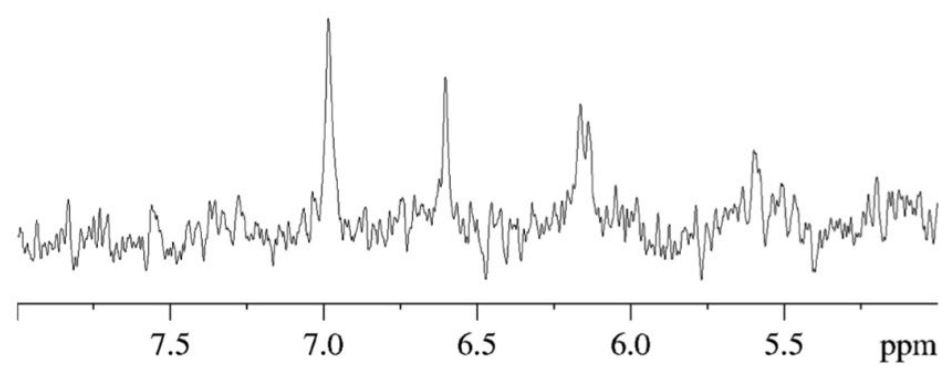

C
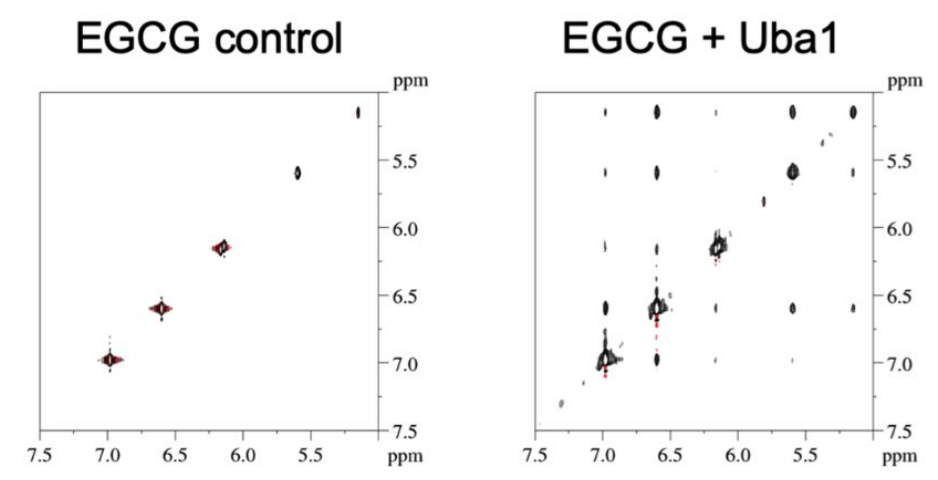

Figure 19. NMR reveals that EGCG directly binds Uba1. (a) Aromatic ${ }^{1} \mathrm{H}$ NMR region of EGCG in the presence of Ubal (red) and without protein (black). (b) STD NMR spectrum recorded for EGCG in the presence of Uba1, aromatic region. (c) TrNOE experiment: no cross-peaks are present in the EGCG control experiment (left), while several cross-peaks appeared in the presence of Ubal (negative NOE due to an equilibrium between the free and the bound state of EGCG). The data suggest a $\mathrm{K}_{d}$ in the range of high $\mathrm{nM}$ to low $\mu \mathrm{M}$, as discussed in the Results and Conclusions section.

\subsection{Dose-response analysis of cell survival}

To get the $\mathrm{IC}_{50}$ values of EGCG and its analogs we assessed cell viability in HEK 293 cells. The cells were treated with EGCG and its analogs for $24 \mathrm{~h}$ with each compound and tested by the Alamar Blue (resazurin) assay relative to parallel-untreated controls. The EGCG and its analogs reduce the viability and growth of HEK 293FT cells (Figure 20). 
The EGCG showed the inhibition with an $\mathrm{IC}_{50}$ value of $220.2 \mu \mathrm{M}$ (see Supplementary

Table 2 for the $\mathrm{IC}_{50}$ values of other analogs).

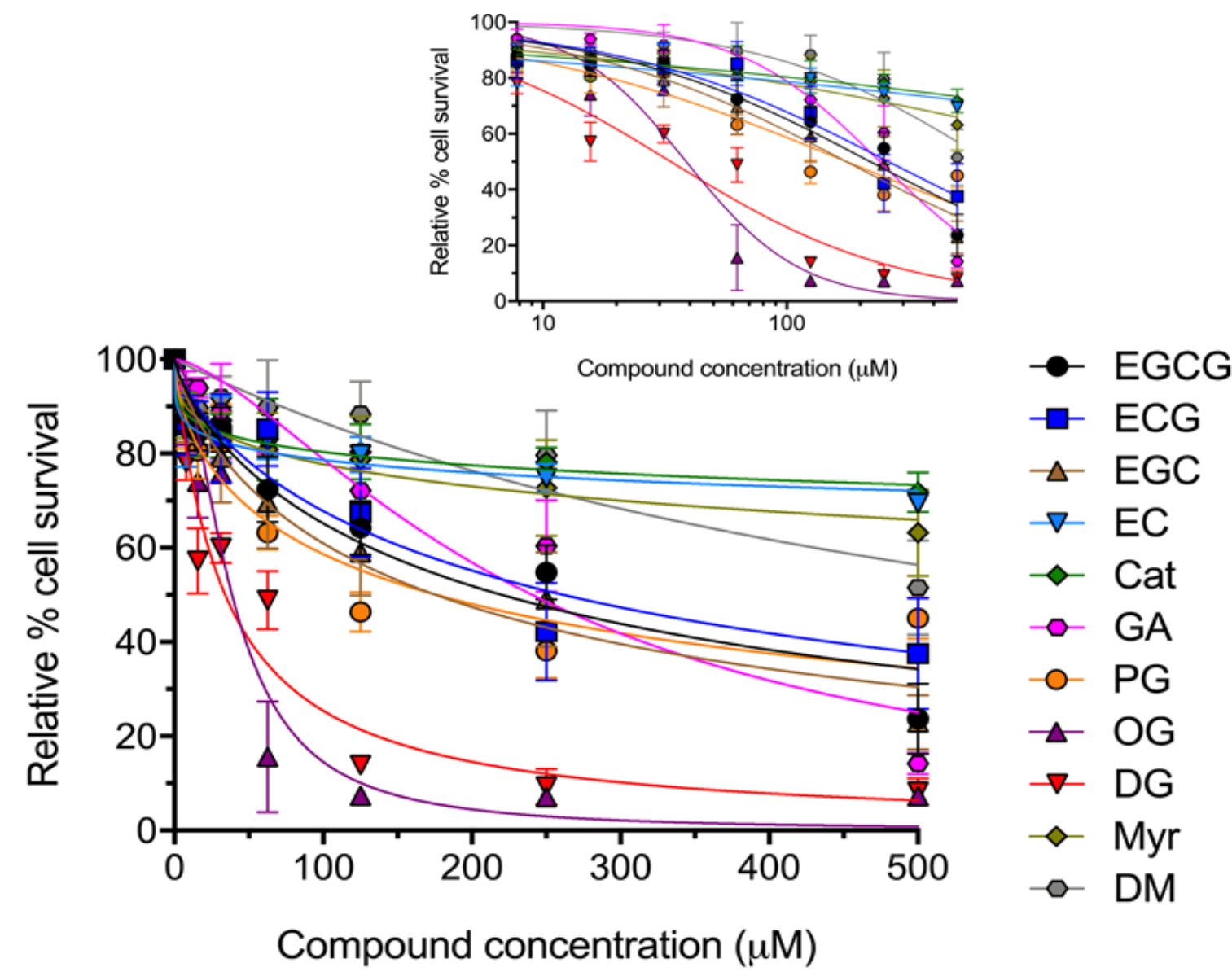

Figure 20. Dose-response for effects on HEK 293 cell survival, after 24-h treatment with each compound relative to parallel untreated controls detected by the Alamar Blue (resazurin) assay. Data represent mean \pm SD for 4-6 independent experiments (as indicated along with $\mathrm{IC}_{50}$ values for each case in Supplementary Table 2), plotted both linearly and semi-logarithmically (inset), with a DMSO concentration of $2 \%$ in all cases.

\subsection{Uba1 or ubiquitin protects the cells from cytotoxic effects of EGCG and EGCG reduces the global ubiquitination in cells.}

To investigate whether overexpression of Uba1 and/or ubiquitin protects the cells from cytotoxic/cytostatic effects of EGCG. The transfected HEK 293 cells overexpressing FLAG-tagged Uba1 or FLAG-tagged ubiquitin exhibited reduced sensitivity to EGCG compared to cells transfected with the FLAG-tag containing empty vector alone (Figure 21). In contrast, the unrelated cytotoxic compound puromycin displayed no differences in 
apparent toxic potency between normal and Uba1- or ubiquitin-overexpressing cells (Figure 21).
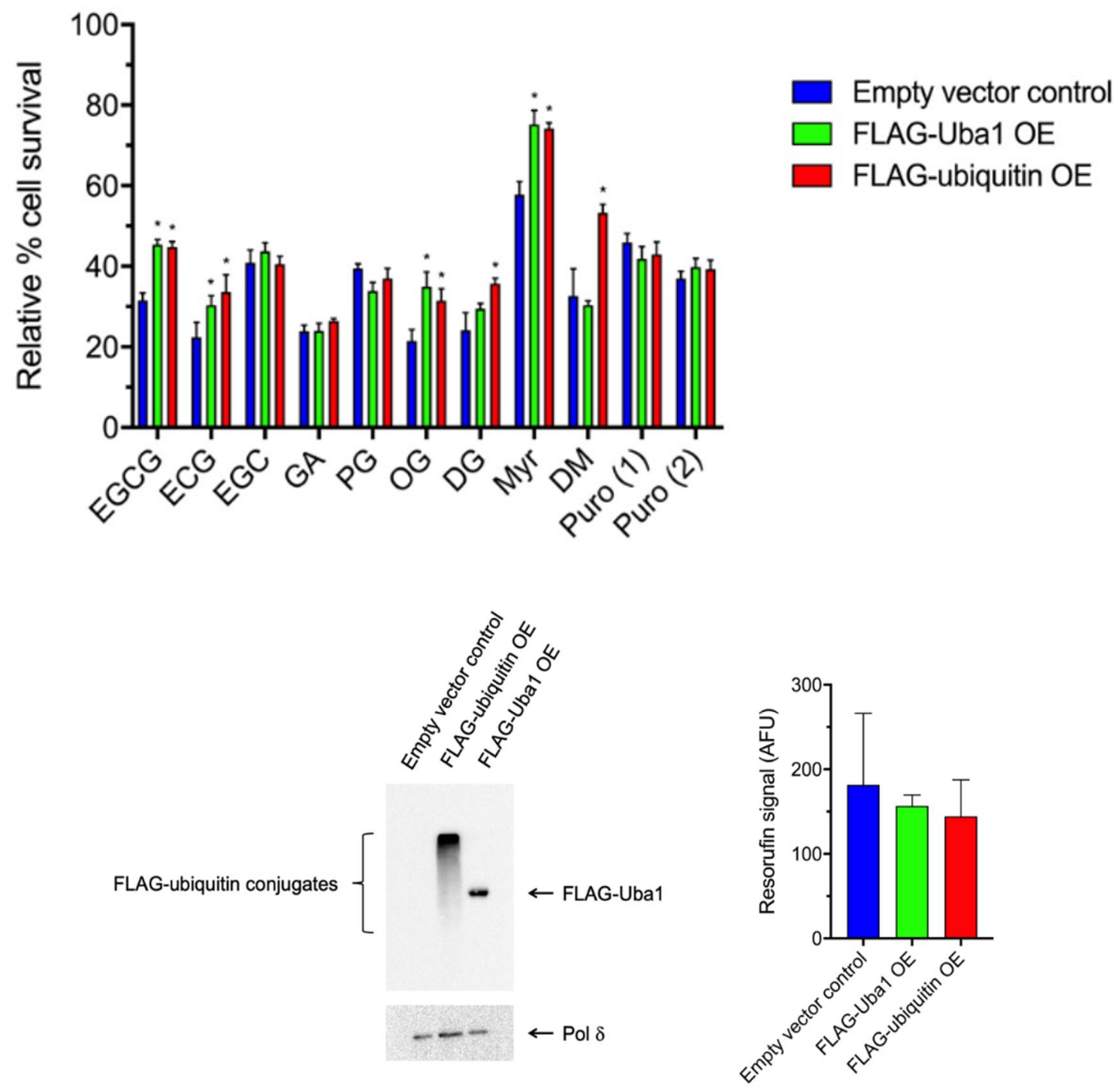

Figure 21. Overexpression of Ubal or ubiquitin reduces the sensitivity of cells to the cytostatic/cytotoxic effects of EGCG. Overexpression of Ubal or ubiquitin reduces the sensitivity of cells to the cytostatic/cytotoxic effects of the compounds that also have in vitro activity against PCNA ubiquitination and Ubal ubiquitin thioester formation but not those without activity. Data represent mean and SD for \% cell survival relative to parallel controls (DMSO alone) for three independent experiments, with a DMSO concentration of $2 \%$ in all cases. Higher survival values following compound treatment between Uba1- or ubiquitin-overexpressing HEK 293 cells compared to the corresponding empty vector-transfected control cells after 24-h compound treatment are indicated with an asterisk ( $p<0.003$ in all cases by unpaired two-tailed Student's $t$-tests). Treatment concentrations were at the $\mathrm{IC}_{50}$ values initially calculated for each compound shown in Supplementary Table 2. 
With the evidence from our biochemical and cellular experiments that indicates EGCG targets Uba, we were interested to test global ubiquitin conjugates in the wholecell lysate. EGCG treatment inhibited the accumulation of ubiquitin-conjugated protein species in HEK 293 cells, in response to treatment with the peptide aldehyde proteasome inhibitor MG132 (Figure 22).

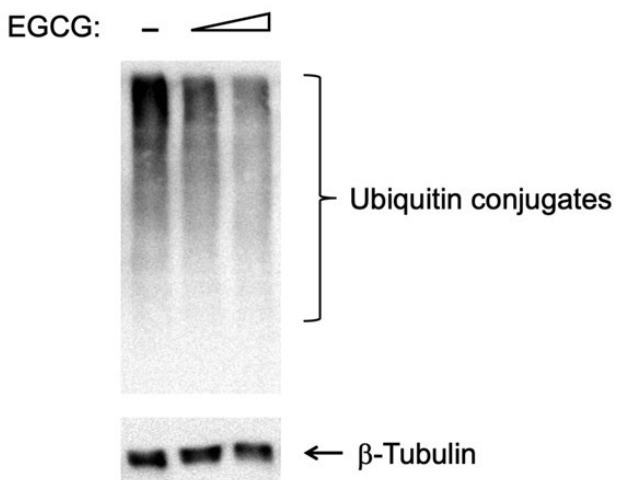

Figure 22. EGCG inhibits global ubiquitination in HEK 293 cells. Representative western blot showing inhibition of global ubiquitination by EGCG in HEK 293 cells. Cells were treated with EGCG at $250 \mu \mathrm{M}$ and $500 \mu \mathrm{M}$ (with DMSO alone as control and a DMSO concentration of $1 \%$ in all cases) for $30 \mathrm{~min}$ and then MG132 was added to $50 \mu \mathrm{M}$. Cells were then incubated for another $30 \mathrm{~min}$, for a total EGCG treatment time of $1 \mathrm{~h}$. Equivalent loadings of total protein from whole-cell lysates were subjected to western blot analysis with anti-ubiquitin antibody and then with anti- $\beta$-tubulin antibody as a housekeeping protein loading control.

\subsection{SAR with EGCG analogs reveals distinct groupings of congeners by structure, activity profile and mechanisms of action}

We tested a series of EGCG-related molecules (structures in Figure 23) for potential inhibitory activity in the same assays as before: PCNA ubiquitination in vitro (Figure 14), Uba1 charging with ubiquitin to form the Uba1 ubiquitin thioester adduct in vitro (Figure 18) and effects on the viability of HEK 293 cells (empty vector-transfected control, Uba1overexpressing and ubiquitin-overexpressing; (Figure 20 and 21). All of the compounds 
tested have molecular weights (170.120-458.375) and predicted $\log \mathrm{P}$ values $(0.72-5.95$, The Lipophilicity plays a significant role in drug discovery and compound design. The lipophilicity of an organic compound can be described by a partition coefficient, $\log \mathrm{P}$, which can be defined as the ratio of the concentration of the unionized compound at an equilibrium between organic and aqueous phases. The $\log \mathrm{P}$ values were calculated with the Consensus model implemented in ChemAxon MarvinSketch 19.2) that suggests no likely questions of low cell permeability. The combined SAR results from Figures 13, 18, 20 and 21 are summarized with structures in Figure 23, with calculated $\mathrm{IC}_{50}$ values for inhibition in the different assays presented in Supplementary Table 2. EGCG was inhibitory in all the assays. The other catechin galloyl ester tested, (-)-epicatechin-3gallate (ECG), was also active in all the assays (Figures 13, 18 and 20) and its inhibitory effect on cell viability was mitigated with the overexpression of Ubal or ubiquitin, as with EGCG (Figure 21). Of the unesterified catechins tested, (-)-epigallocatechin (EGC) displayed weak activity in the PCNA ubiquitination (Figure 14) and Uba1 ubiquitin thioester formation assays (Figure 18) while (-)-epicatechin (EC) and (+)-catechin (Cat) were inactive in both of these assays (Figures 13 and 18). Unlike EC and Cat, EGC also has measurable cytostatic/cytotoxic activity (Figure 20). However, EGC's negative effect on cell survival was not affected by Uba1 or ubiquitin overexpression (Figure 21). Free gallic acid (GA) and n-propyl gallate (PG), a short straight-chain alkyl galloyl ester, were inactive in the PCNA ubiquitination (Figure 14) and Uba1 ubiquitin thioester formation assays (Figure 18) but had little effects on cell viability (Figure 20). What inhibitory activity was observed was not mitigated with Ubal or ubiquitin overexpression (Figure 21). Longer linear alkyl galloyl esters-n-octyl gallate (OG) and n-dodecyl (lauryl) gallate (DG)—were active in all the assays (Figures 13, 18 and 20) and overexpression of Uba1 or ubiquitin protected cells from their negative effects on cell survival (Figure 21). 
Myricetin (Myr) and (+)-dihydromyricetin (DM; also known as ampelopsin) were active against PCNA ubiquitination (Figure 14) and Uba1 ubiquitin thioester formation (Figure 18) but only had very weak activity against cell survival (Figure 20), although cells were protected from even that weak cytostatic/cytotoxic activity by overexpression of Ubal or ubiquitin (Figure 21). The alkyl gallates inhibited PCNA ubiquitination and Ubal ubiquitin thioester formation with a potency directly proportional to the length of their alkyl chains in the rank order: DG $>$ OG $\gg$ PG (the last one more-or-less inactive); Myr and DM also inhibited PCNA ubiquitination and Uba1 ubiquitin thioester formation in the order: Myr $\gg$ DM (Figures 13, 18, 20 and Supplementary Table 2). However, with Myr, unlike with EGCG, pre-incubation of not only Uba1 alone but also ubiquitin alone prior to adding the other reaction components for thioester formation resulted in inhibition (Figure 15). Since the presence of a Michael acceptor functionality in Myr makes a mechanism involving a covalent reaction with the target, which often but not always is irreversible, we tested whether Myr irreversibly inhibits PCNA ubiquitination or not by determining if enzyme activity recovers after washing out of the compound through serial centrifugal filtration. Myr's inhibitory effects on PCNA ubiquitination, like EGCG's, were reversible (Figure 16). 


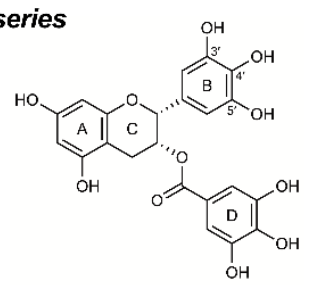

(-)-Epigallocatechin-3-gallate (EGCG)

(-)-Epigallocatechin-3-gal
$\mathrm{IC}_{50}$ (PCNA-Ub) $=228 \mathrm{nM}$

$\mathrm{IC}_{50}(\mathrm{Uba} 1 \sim \mathrm{Ub})=1.6 \mu \mathrm{M}$

$\mathrm{IC}_{50}$ (cell survival) $=220 \mu \mathrm{M}$

Uba1 OE effect: Protects

Ub OE effect: Protects<smiles>O=C(O[C@H]1Cc2c(O)cc(O)cc2O[C@@H]1c1ccc(O)c(O)c1)c1cc(O)c(O)c(O)c1</smiles>

(-)-Epicatechin-3-gallate (ECG) $\mathrm{IC}_{50}$ (PCNA-Ub) $=540 \mathrm{nM}$ $\mathrm{IC}_{50}(\mathrm{Uba1} \sim \mathrm{Ub})=4.2 \mu \mathrm{M}$

$I_{50}$ (cell survival) $=262 \mu \mathrm{M}$ Uba1 OE effect: Protects

\section{Simple catechin series}<smiles>Oc1cc(O)c2c(c1)O[C@H](c1cc(O)c(O)c(O)c1)[C@H](O)C2</smiles>

$$
\begin{aligned}
& \text { (-)-Epigallocatechin (EGC) } \\
& I \mathrm{C}_{50} \text { (PCNA-Ub) }=43.3 \mu \mathrm{M} \\
& I \mathrm{C}_{50} \text { (Uba1 Ub) }=7.6 \mu \mathrm{M} \\
& \mathrm{I} \mathrm{C}_{50} \text { (cell survival) }=176 \mu \mathrm{M} \\
& \text { Uba1 OE effect: Does not protect } \\
& \text { Ub OE effect: Does not protect }
\end{aligned}
$$<smiles>Oc1cc(O)c2c(c1)O[C@H](c1ccc(O)c(O)c1)[C@H](O)C2</smiles>

(-)-Epicatechin (EC) $\mathrm{IC}_{50}$ (PCNA-Ub) $>500 \mu \mathrm{M}$ $\mathrm{IC}_{50}$ (Uba1 Ub) $>500 \mu \mathrm{M}$ $\mathrm{IC}_{50}$ (cell survival) $>500 \mathrm{uM}$ Uba1 OE effect: N/A Ub OE effect: N/A<smiles>Oc1cc(O)c2c(c1)O[C@H](c1ccc(O)c(O)c1)[C@H](O)C2</smiles>

(+)-Catechin (Cat) $\mathrm{IC}_{50}$ (PCNA-Ub) $>500 \mu \mathrm{M}$ $\mathrm{IC}_{50}$ (Uba1 Ub) $>500 \mu \mathrm{M}$ $\mathrm{IC}_{50}$ (cell survival) $>500 \mu \mathrm{M}$ Uba1 OE effect: N/A Ub OE effect: N/A

\section{Simple gallate series}<smiles>O=C(O)c1cc(O)c(O)c(O)c1</smiles>

\section{Gallic acid (GA)}

$\mathrm{IC}_{50}$ (PCNA-Ub) $>500 \mu \mathrm{M}$

$\mathrm{IC}_{50}(\mathrm{Uba1} \sim \mathrm{Ub})>500 \mu \mathrm{M}$

$\mathrm{IC}_{50}$ (cell survival) $=241 \mu \mathrm{M}$

Uba1 OE effect: Does not protect Ub OE effect: Does not protect<smiles>CCOC(=O)c1cc(O)c(O)c(O)c1</smiles>

n-Propyl gallate (PG)

$I_{50}$ (PCNA-Ub) $>500 \mu \mathrm{M}$

$\mathrm{IC}_{50}$ (PCNA-Ub) $>500 \mu \mathrm{M}$

$I_{50}$ (cell survival) $=176 \mu \mathrm{M}$

Uba1 OE effect: Does not protect

Ub OE effect: Does not protect<smiles>CCOC(=O)c1cc(O)c(O)c(O)c1</smiles>

n-Octyl gallate (OG) $\mathrm{IC}_{50}$ (PCNA-Ub) $=10.3 \mu \mathrm{M}$ $\mathrm{IC}_{50}(\mathrm{Uba} 1 \sim \mathrm{Ub})=80.6 \mu \mathrm{M}$ $\mathrm{IC}_{50}$ (cell survival) $=38.7 \mu \mathrm{M}$ Uba1 OE effect: Protects Ub OE effect: Protects<smiles>CCOC(=O)c1cc(O)c(O)c(O)c1</smiles>

n-Dodecyl gallate (DG) $I_{50}$ (PCNA-Ub) $=1.6 \mu \mathrm{M}$ $\mathrm{IC}_{50}$ (Uba1 $\left.\sim \mathrm{Ub}\right)=35.0 \mu \mathrm{M}$

$\mathrm{IC}_{50}$ (cell survival) $=33.5 \mathrm{\mu M}$ Uba1 OE effect: Does not protect Ub OE effect: Protects

\section{Myricetin series}

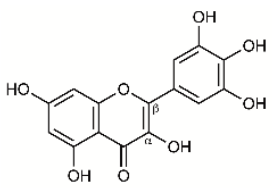

Myricetin (Myr)

$\mathrm{IC}_{50}$ (PCNA-Ub) $=1.2 \mu \mathrm{M}$

$I_{50}$ (Uba1 Ub) $=721 \mathrm{nM}$

$\mathrm{IC}_{50}$ (cell survival) $>500 \mu \mathrm{M}$

Uba1 OE effect: Protects<smiles>O=C1c2c(O)cc(O)cc2O[C@H](c2cc(O)c(O)c(O)c2)C1O</smiles>

(+)-Dihydromyricetin (DM) $\mathrm{IC}_{50}$ (PCNA-Ub) $=66.4 \mu \mathrm{M}$ $\mathrm{IC}_{50}(\mathrm{Uba1} \sim \mathrm{Ub})=14.3 \mu \mathrm{M}$

$I_{50}$ (cell survival) $>500 \mu \mathrm{M}$

Uba1 OE effect: Does not protect Ub OE effect: Protects

Figure 23. Structure-activity relationships for inhibition of PCNA ubiquitination, Ubal ubiquitin thioester formation and viability of normal, Uba1-overexpressing and ubiquitin-overexpressing cells. $\mathrm{OE}=$ overexpression, $\mathrm{N} / \mathrm{A}=$ not applicable. 


\subsection{Robust high-throughput assays to assess discrete steps in PCNA ubiquitination}

Starting from the conditions we optimized previously for Western blot analysis and the quantitation of PCNA ubiquitination (50 nM Uba1, $50 \mathrm{nM}$ RFC, $50 \mathrm{nM}$ FLAG-PCNA, $250 \mathrm{nM}$ biotin-ubiquitin, $250 \mathrm{nM}$ Rad6-Rad18, $2 \mathrm{mM}$ ATP and $2.5 \mathrm{nM}$ DNA), we used these conditions as a reference for the development of site-specific secondary PCNA ubiquitination assay. In the process, we developed a high-throughput Alpha-based PCNA ubiquitination assay that balances high sensitivity with low consumption of reagents, as well as analogous assays to probe Uba1 ubiquitin thioester formation, Rad6 ubiquitin thioester formation, Rad6-Rad18 interaction and Rad18 auto-ubiquitination (Figure 24).

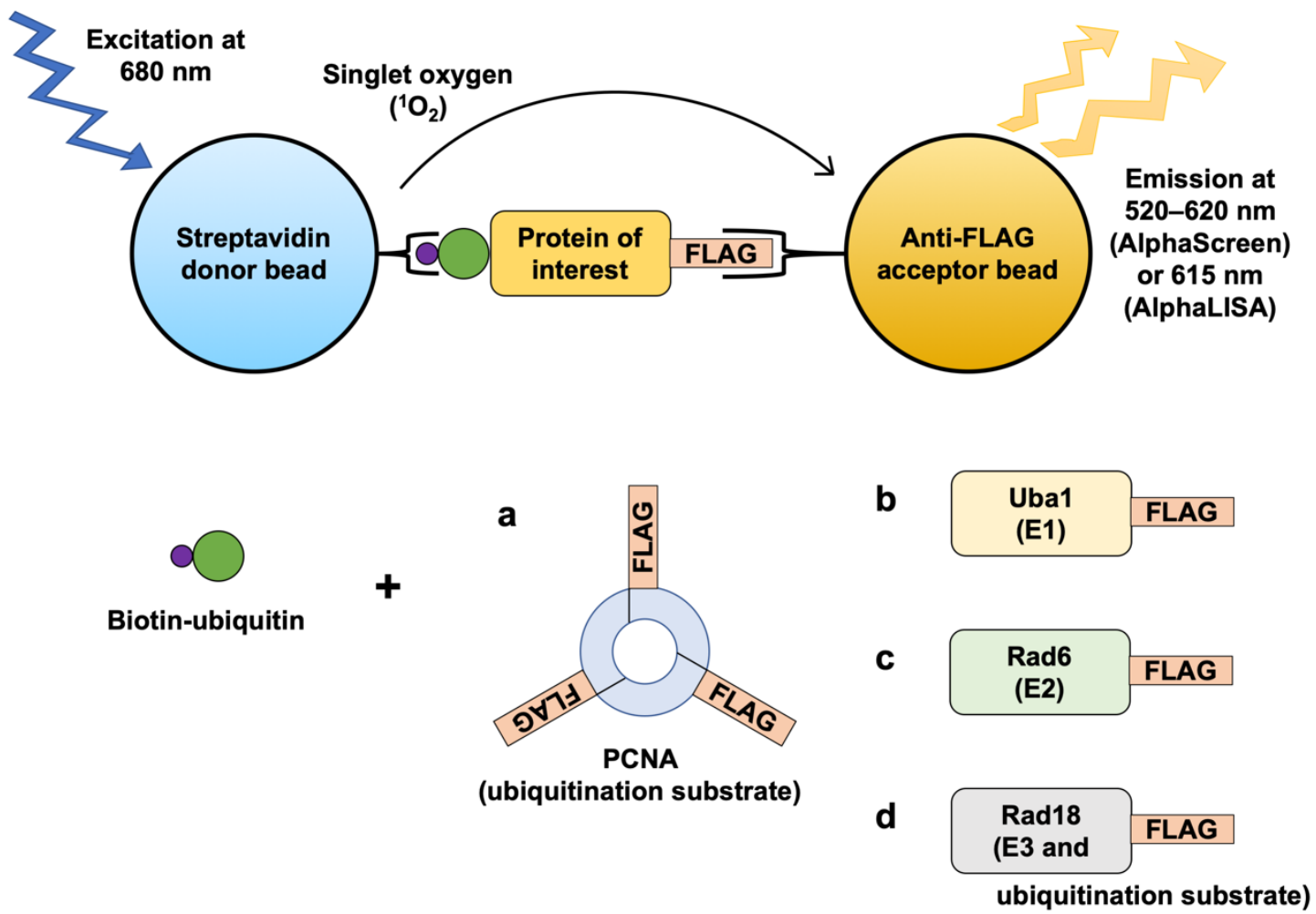

Figure 24. Diagram of the Alpha assays for A. PCNA ubiquitination, B. Ubal ubiquitin thioester formation, C. Rad6 ubiquitin thioester formation and D. Rad18 autoubiquitination. 


\subsubsection{Development of an Alpha assay for Uba1 ubiquitin thioester formation}

First, we adapted the Alpha system for the quantitative evaluation of Uba1 ubiquitin thioester formation, again starting with the conditions we previously worked out for gelbased detection (described above) and then refined for Alpha detection. We individually varied concentrations of the analytes, FLAG-Uba1 (Figure 25a) and biotin-ubiquitin (Figure 25b) and we found conditions yielding good results which $50 \mathrm{nM}$ FLAG-Uba1 and $150 \mathrm{nM}$ biotin-ubiquitin

a

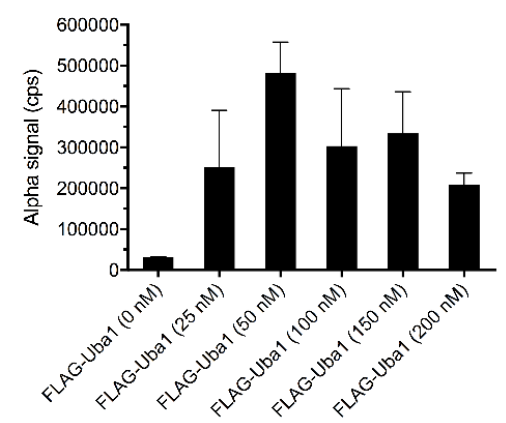

b

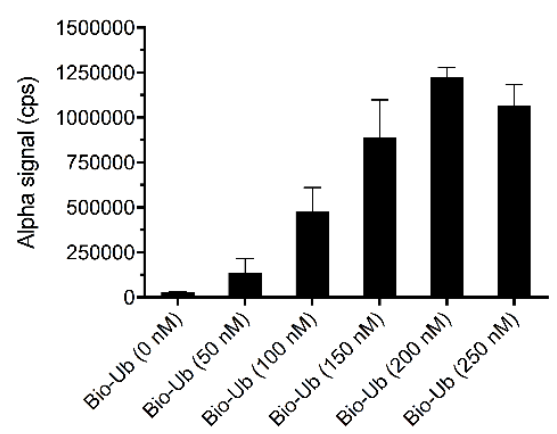

Figure 25. Alpha assay for Uba1 ubiquitin thioester formation. a. Variable concentrations of FLAG-Ubal and b. biotin-ubiquitin (Bio-Ub) in the Ubal ubiquitin thioester formation assay

\subsubsection{Development of an Alpha assay for Rad6 ubiquitin thioester formation}

We developed an Alpha assay for the detection of Rad6 ubiquitin thioester formation, again starting from conditions previously developed for gel-based detection. We generated a FLAG-Rad6 construct and performed reactions with non-FLAG-tagged Uba1 and biotin-ubiquitin. We individually varied concentrations of biotin-ubiquitin (Figure 26a) and FLAG-Rad6 (Figure 26b) in single-well, "one-pot" reactions which resulted in satisfactory results. Thus, we chose $150 \mathrm{nM}$ biotin-ubiquitin and $50 \mathrm{nM}$ FLAG-Rad6 for further optimization. We then split the two-reaction sequence into two steps to allow for 
more narrow screening for direct Rad6 modulators as distinct from those that secondarily affect Rad6 by instead directly targeting Uba1, with a first step for Uba1 charging with ubiquitin and then a second step where the precharged Uba1 ubiquitin was combined with Rad6 (preincubated with compound in a screening setting) for the transthioesterification reaction. We found comparably good results to the one-pot reaction sequence.

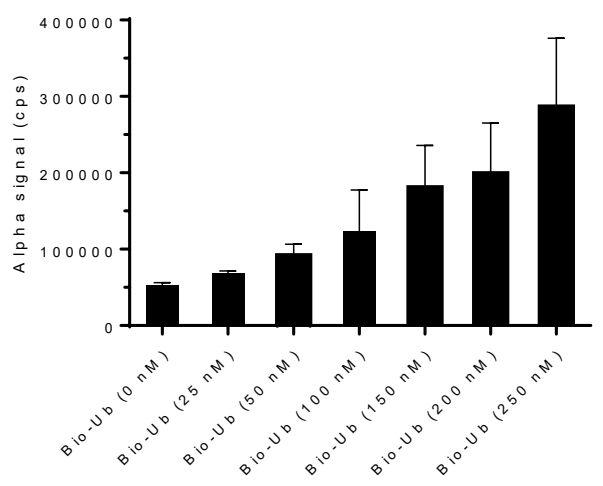

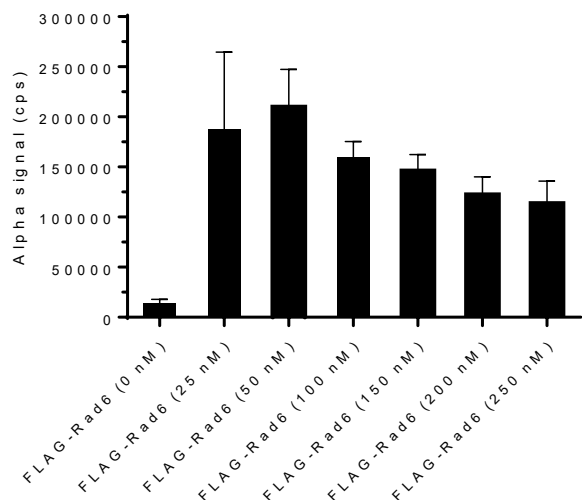

Figure 26. Alpha assay for Rad6 ubiquitin thioester formation assay. Titration of FLAG-Rad6 and biotin-ubiquitin in the a. FLAG-Rad6 and b. biotin-ubiquitin (Bio-Ub) in the Rad6 ubiquitin thioester formation assay.

We experimented with adding EDTA to the precharged Ubal ubiquitin samples before adding Rad6 to chelate the $\mathrm{Mg}^{2+}$ and prevent further ATP-dependent charging of Uba1 with ubiquitin after mixed with Rad6, so that the assay would be a potentially cleaner transthioesterification (despite being a step not requiring $\mathrm{Mg}^{2+}$-ATP) to evaluate Rad6 ubiquitin thioester formation solely. However, we found that adding EDTA at this step, for some reason, decreased transfer of the ubiquitin moiety from Uba1 to Rad6 (Figure 27). Another possibility to prevent further Uba1 charging would be to add apyrase to cleave ATP between the steps, however, since the assay worked clean enough in the 
simpler form, we concluded that the addition of another protein component in a screening setting may not be warranted.

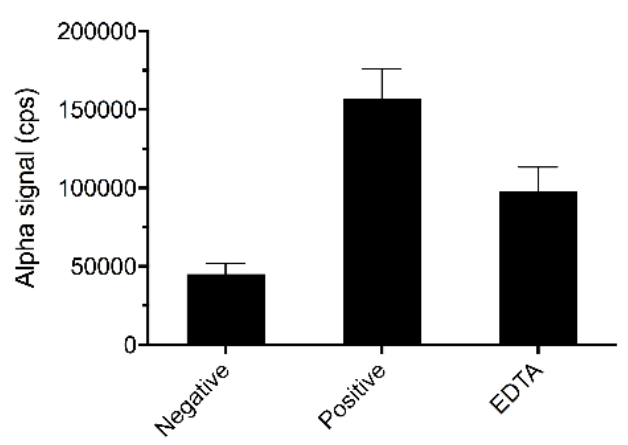

Figure 27. Two-step Rad6 ubiquitin thioester formation assay, with precharging of Ubal with biotin-ubiquitin prior to addition of Rad6, with or without EDTA (added between steps to chelate $\mathrm{Mg}^{2+}$ and prevent further ATP-dependent Ubal charging with ubiquitin); negative control was without ATP, while the positive control and EDTA-treated samples included ATP.

\subsubsection{Development of a Rad6-Rad18 interaction assay}

We developed an Alpha assay for the detection of Rad6-Rad18 interaction. We performed reactions with FLAG-tagged Rad6 and His-tagged Rad18. The concentrations of FLAGRad6 and 6xHis-Rad18 were kept in equal ratio and tested in a gradient from $6.25 \mathrm{nM}$ to $200 \mathrm{nM}$ and again we found conditions that resulted in good outcomes which is $100 \mathrm{nM}$ of each FLAG-Rad6 and His-Rad18 (see in figure 28).

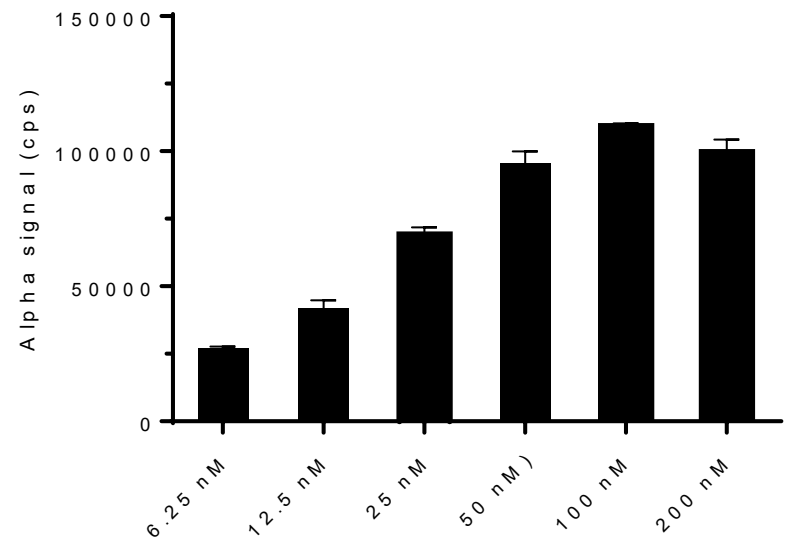

Figure 28. Alpha assay for Rad6-Rad18 interaction. The equimolar concentrations of FLAG-Rad6 and His-Rad18 were tested by going higher in $2 \mathrm{x}$ increments from $6.25 \mathrm{nM}$ up to $200 \mathrm{nM}$. 


\subsubsection{Development of a Rad18 autoubiquitination assay}

We developed an Alpha assay for the detection of Rad18 autoubiquitination. We constructed a FLAG-Rad18 construct and performed reactions with non-FLAG-tagged Uba1, non-FLAG-tagged Rad6 and biotin-ubiquitin. Concentrations of FLAG-Rad18 (Figure 29a) and biotin-ubiquitin (Figure 29b) for this reaction were also varied and again the conditions that resulted in good outcomes. The final conditions based on titration results we chose $100 \mathrm{nM}$ FLAG-18 and $100 \mathrm{nM}$ biotin-ubiquitin.

a

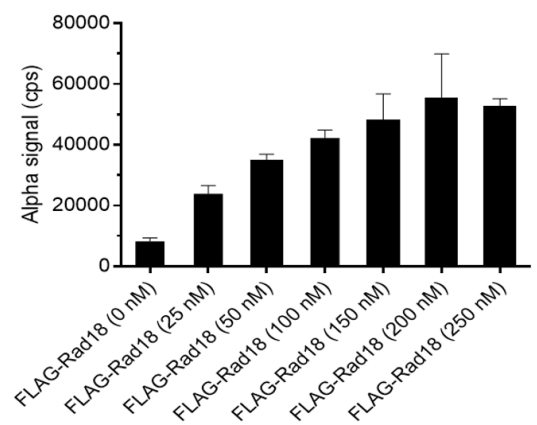

b

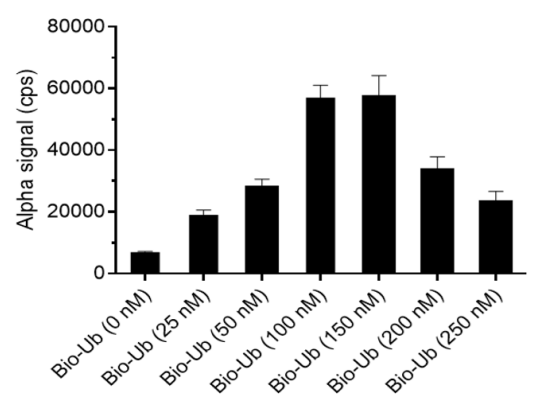

Figure 29. Titration of FLAG-Rad18 and biotin-ubiquitin in the Rad18 autoubiquitination assay. a. FLAG-Rad18 and b. biotin-ubiquitin (Bio-Ub) 


\subsection{Validation of the assays}

In addition to evaluating plate quality control metrics by multiple measures (including Z' factors and SSMD values in standard/robust statistical forms to compare positive and negative control values, as well as signal-to-background ratios, signal-to-noise ratios and signal window values), we further validated the first three Alpha assays with inhibitors of ubiquitination we discovered through gel based approach (Fenteany et al. 2020). We performed dose-response experiments with the Alpha assays for PCNA ubiquitination (Figure 30) and Uba1 ubiquitin thioester formation (Figure 31). The structure-activity relationships were similar to those described in Figure 14, 18, 20, 21 and 23, with comparable calculated half-maximal inhibitory concentration $\left(\mathrm{IC}_{50}\right)$ values for each of the bioactive compounds, as also shown in Supplementary Table 3. Furthermore, our ongoing screening efforts suggest that all of the assays yield predictive results, confirmable by other lower-throughput, more traditional assays, in terms of reliable normalized percentages of difference from controls and hit selection criteria $(z$ scores and hitselection SSMD values) relative to overall experimental means or medians in both standard and robust statistical forms, respectively. 
a
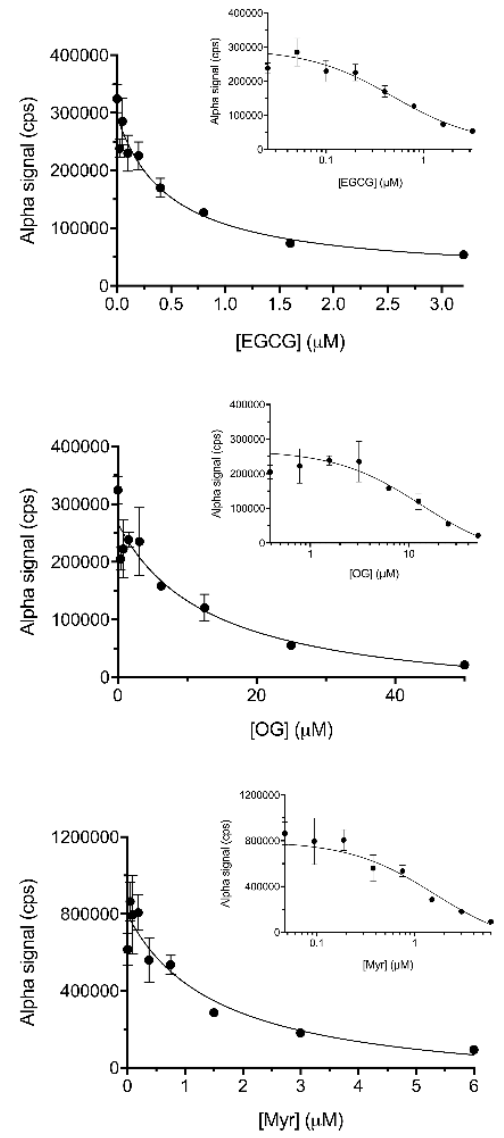

b

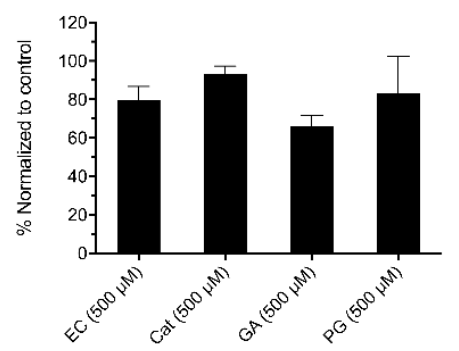

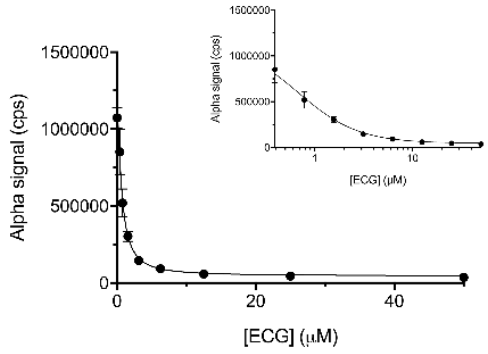
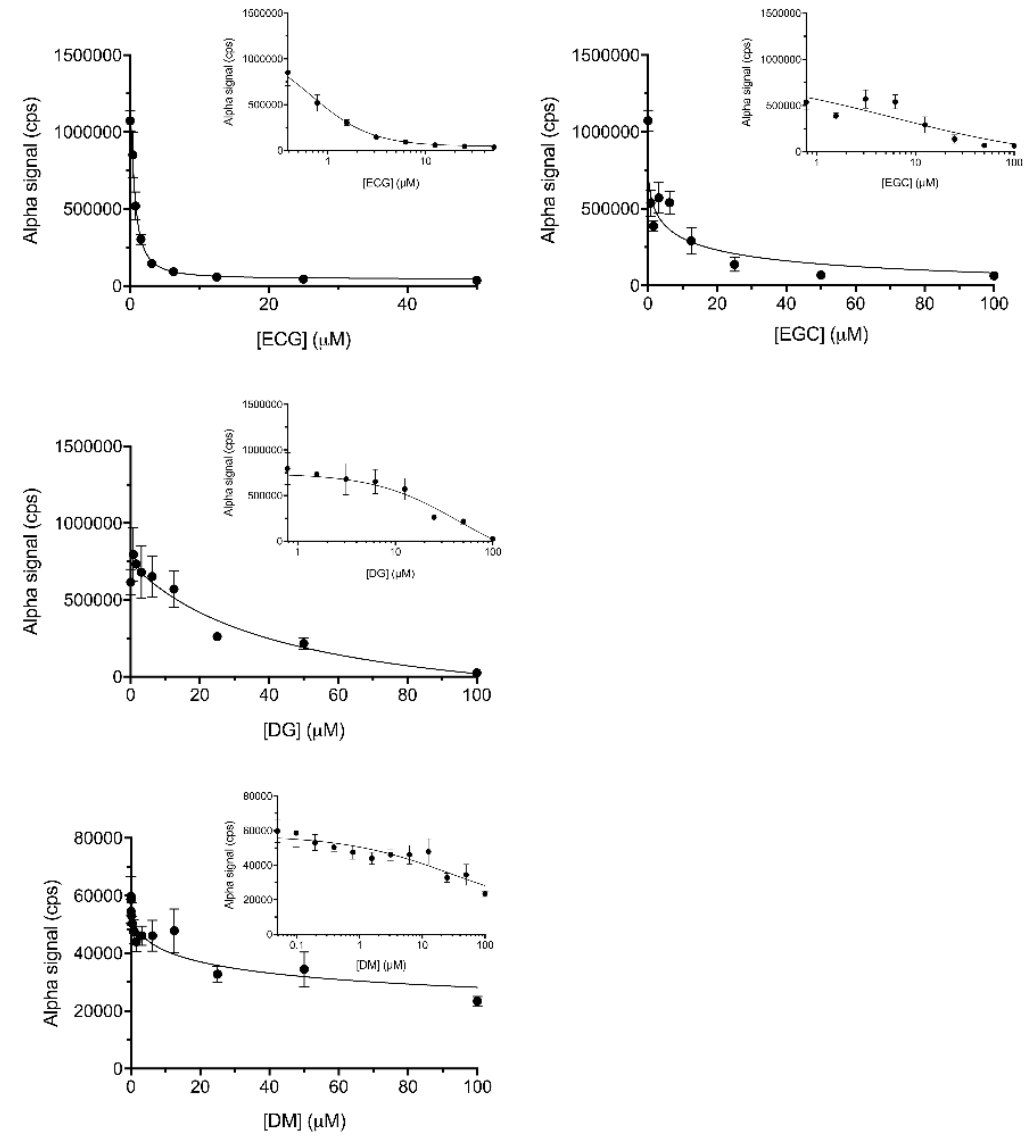
a
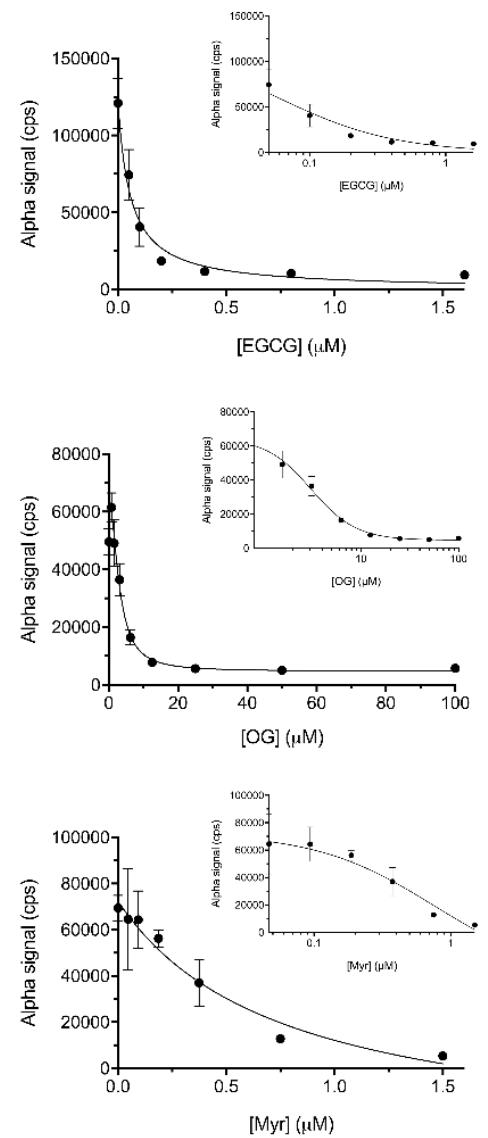

b

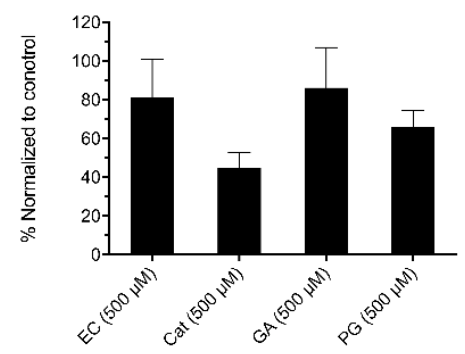

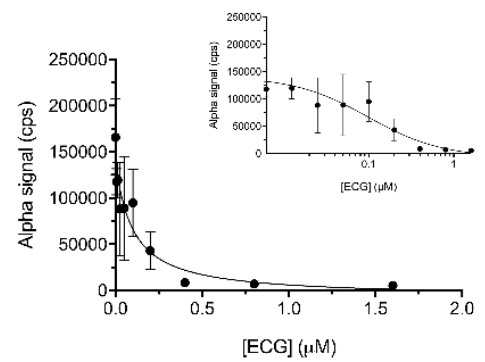
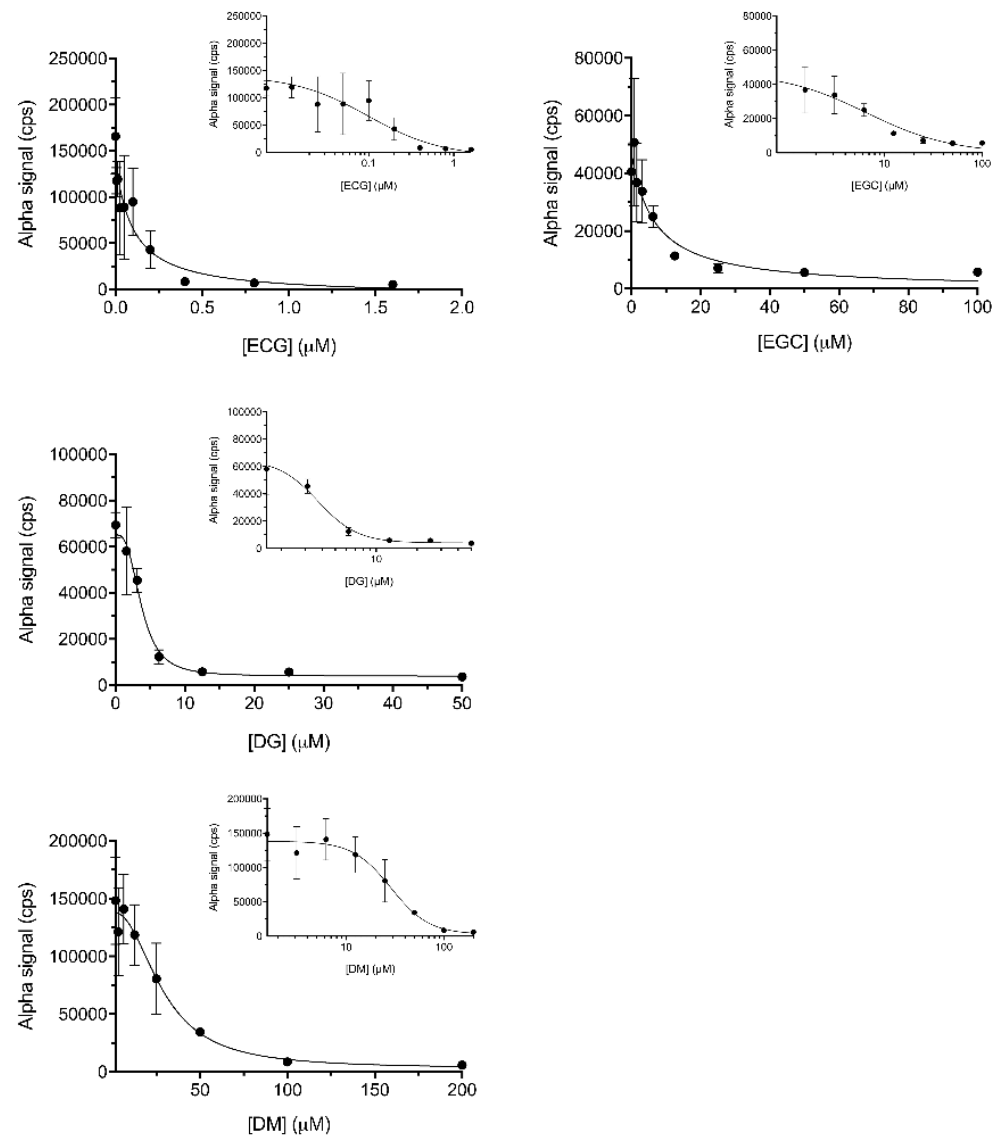

Figure 31. Dose-response for EGCG and analogs in the Uba1 ubiquitin formation assay. Data represent mean and SD for 3-5 samples in each case. The final DMSO concentration was $1 \%$ in all cases. FLAG-Ubal samples were pre-incubated with compounds for 15 min before addition of biotin-ubiquitin and ATP. a Dose-response for bioactive inhibitors of Ubal ubiquitin thioester formation, plotted both linearly and semi-logarithmically (inset). b Effect of compounds with little activity against Uba1 ubiquitin thioester formation at $500 \mu \mathrm{M}$, normalized to positive (DMSO alone) control values. 


\section{Discussion}

We have designed and implemented a powerful quantitative, robust high-throughput assay for PCNA ubiquitination, which is a key early event in DNA damage tolerance processes. Firstly, we developed alpha assay for PCNA ubiquitination based on preoptimized conditions (50 nM Uba1, 50 nM RFC, 50 nM FLAG-PCNA, 250 nM biotinubiquitin, $250 \mathrm{nM}$ Rad6-Rad18, 2 mM ATP and $2.5 \mathrm{nM}$ DNA). We compared the efficacy of PCNA ubiquitination as performed through Alpha assay with western blot and found the signals to be satisfactory (figure 7). Afterward, we further optimized the reconstituted system for a more sensitive Alpha technology. We sought to reduce the concentrations of components by the PCNA ubiquitination reaction cascade to further optimize and miniaturize the overall subsequent detection step. Thus, we developed a high-throughput Alpha-based PCNA ubiquitination assay that balances high sensitivity with low consumption of reagents, as well as step-specific assays to probe Uba1 ubiquitin thioester formation, Rad6 ubiquitin thioester formation, Rad6-Rad18 interaction and $\operatorname{Rad} 18$ autoubiquitination.

In the alpha assay, upon high energy illumination with $680 \mathrm{~nm}$ wavelength light, the phthalocyanine in the donor beads converts ambient oxygen into the excited form. The excited singlet oxygen has a half-life of $4 \mu$ s and it can travel up to $200 \mathrm{~nm}$ distance. In case, if the acceptor beads are in the diameter of $200 \mathrm{~nm}$, energy from excited singlet oxygen is transferred to thioxene derivatives in acceptor beads subsequently generating 520-620 nm wavelength light in case of Alphascreen and $615 \mathrm{~nm}$ in case of AlphaLISA, which are detected by a photomultiplier tube. In case, if there are no acceptor beads in the 
proximity of donor beads, excited singlet oxygen falls to ground state and no signal is produced.

PerkinElmer's Alpha technology has two variants Alpha Screen and AlphaLISA both are similar with a minor difference only in the dyes of acceptor beads. The Alphascreen acceptor beads have three dyes, thioxene, anthracene and rubrene while in AlphaLISA anthracene and rubrene are substituted with europium chelate. The conversion of thioxene to di-ketone derivative by excited singlet oxygen emits $340 \mathrm{~nm}$ light which further excites europium chelate resulting in narrower wavelength light $(615 \mathrm{~nm})$ unlike in Alphascreen. We have tested both the subtypes of alpha technology and we don't see many variations in our experimental system. We chose AlphaScreen beads because they are available in a kit form (streptavidin donor and anti-FLAG acceptor beads), making it an economical option, unlike AlphaLISA.

The optimized step-specific PCNA ubiquitination assays have good dynamic signal range, reproducible, consistent but precise signal intensity values of the range can vary from experiment to experiment. Even under identical conditions, alpha counts can display different absolute signals, although internally a given experiment will be uniform and consistent in trends with others. Perkin Elmer is aware of this issue and technical support has no good explanation for it. The important thing is that all experiments are internally consistent and after normalization of data, different experiments can be compared. Thus, screening data from multiple experiments with replicates should be considered only after normalization. Here normalization means, percentage difference from positives in each plate.

The Alpha assay is susceptible to the high-dose hook effect like many other bimolecular assays. Wherein, too high concentrations of analytes can result in an absolute drop in 
signal. The hook effect also referred to as the hooking or prozone effect. It is named after the shape of the analyte concentration-signal curve which resembles a fish hook.

By screening of chemical compounds on our alpha assay for PCNA ubiquitination, we discovered EGCG as a potent inhibitor of ubiquitination (Alpha-based PCNA ubiquitination assay was the first assay developed in our lab with pre-optimized western blot based assay conditions with which we discovered EGCG as a primary hit. Further, we pursued it and characterized it through gel-based assay and published our results about EGCG and in the background, we worked on further optimization, development of stepspecific secondary assays and validation of $\mathrm{IC}_{50}$ obtained from gel-based assay. EGCG is the most active component of green tea. EGCG is known for its anti-angiogenic, anticarcinogenic, anti-oxidant, anti-microbial and anti-inflammatory (Chakrawarti et al. 2016). We found that EGCG abrogates the formation of Uba1 ubiquitin thioester conjugate, but not the formation of the Rad6 ubiquitin thioester conjugate resulting from the transfer of the ubiquitin moiety from already formed Ubal ubiquitin. The two most common mechanisms to inhibit Uba1 ubiquitin thioester conjugate could be either by targeting ubiquitin or Ubal protein. To investigate this, we carried out preincubation experiments where we individually preincubated Uba1 and ubiquitin with EGCG, afterward other components were added (Figure15). We found out that the preincubation of EGCG with Uba1 protein inhibits the formation of Uba1 ubiquitin thioester conjugate not with ubiquitin. This implies that ATP and/or ubiquitin compete effectively with EGCG for binding to Uba1 and so EGCG may bind the ATP- or ubiquitin-binding site of Uba1. Further, we determined that EGCG binds Uba1 by ligand-detected ${ }^{1} \mathrm{H}$ NMR methods with an approximated $\mathrm{K}_{\mathrm{d}}$ in a range similar to the $\mathrm{IC}_{50}$ values for inhibition of PCNA ubiquitination and Uba1 ubiquitin thioester formation by EGCG, strongly 
suggesting that it is the direct binding of Ubal that accounts for the overall inhibitory activity.

EGCG inhibits the autoubiquitination of the E3 ubiquitin ligase TRAF6 (J. Zhang et al. 2016; A. K. Singh et al. 2016). The reduced TRAF6 ubiquitination could be the result of upstream inhibition of Uba1 and not necessarily TRAF6 directly. TRAF6, like Rad18, contains a so-called really interesting new gene (RING) zinc finger domain, thought to be involved in protein-protein interactions. We have no evidence so far that EGCG directly inhibits Rad18 instead our results suggest that EGCG inhibits ubiquitination at the level of Uba1. Uba1 has been proposed as a target for the treatment of cancers and other pathological states linked to detrimental levels of ubiquitin-proteasome activity and other ubiquitination-dependent activities (Xu et al. 2013; Groen and Gillingwater 2015).

The diverse role of ubiquitination in regulating protein homeostasis and ubiquitin signaling indicates the possibility of targeting the ubiquitination pathway to modulate human disease. The ubiquitin-proteasome pathway has been mostly validated by the success of the proteasome inhibitor bortezomib (Einsele 2014) in the treatment of multiple myeloma. However, investigations to validate Uba1 itself as a drug target are still few.

The first Ubal inhibitor panepophenanthrin was discovered from the mushroom strain Panus rudis Fr. IFO8994 (Sekizawa et al. 2002). It weakly inhibited the Uba1 ubiquitin thioester formation in vitro with an $\mathrm{IC}_{50}$ of $72 \mu \mathrm{M}$, the activity in cells was not detected. After that there have been other Ubal inhibitors reported such as himeic acid which inhibits with 60-100 $\mu \mathrm{M}$ range (Tsukamoto et al. 2005). Other Uba1 reported are NSC 622406, largazole that inhibits Uba1 ubiquitin thioester at the adenylation step and small molecule hyrtioreticulins A-E inhibitors (J. Hong and Luesch 2012; Ungermannova et al. 2013; 2012; Yamanokuchi et al. 2012). 
Further, other strong inhibitors such as pyrazolidines PYR-4150 and PYZD-440951 and the adenosine sulfamate TAK-243 (formerly known as MLN7243) (Hyer et al. 2018; Y. Yang et al. 2007) have been found to target Uba1. TAK-243 is a potent mechanism-based inhibitor of the charging of Ubal with ubiquitin that acts by forming a stable covalent adduct with the C-terminal carboxylate of ubiquitin. TAK-243 and related reactive adenosine derivatives also likewise indirectly inhibit the E1 enzymes of other ubiquitinlike proteins to varying degrees (Hyer et al. 2018; Soucy et al. 2009; An and Statsyuk 2013). In contrast, although considerably less potent than TAK-243, EGCG, myricetin and the PYR-41 appears to directly inactivate Uba1 itself rather than ubiquitin (Y. Yang et al. 2007). TAK-243 and PYR-41 also differ in some of their biological effects (Monda and Cheeseman 2018).

Besides, Uba1 being the EGCG target relevant to ubiquitination cascade, Uba1 may account for part of EGCG's overall cellular effects. We found that overexpression of Uba1 in cells reduces the EGCG's cytostatic and cytotoxic effects, consistent with Ubal being a major intracellular EGCG-binding protein in the cell. This is most likely the result of titration of free EGCG by higher Ubal concentrations in the cell with overexpression. We also observed such protective effects with overexpression of ubiquitin, further suggesting that the ubiquitination pathway is being targeted in the cell and this is still consistent with the hypothesis that Ubal is the direct target of EGCG relevant to ubiquitination. The productive reaction of the Uba1 ubiquitin thioester conjugate is trimolecular (involving Uba1 as a covalent catalyst and ubiquitin and ATP as substrates) and overexpression of a binding partner of the direct target could be protective if EGCG binds the target competitively with that additional component. The protective effects of Ubal or ubiquitin overexpression are specific for EGCG and its biochemically active analogs since neither manipulation affects the sensitivity of cells to inactive analogs or puromycin, a well- 
characterized protein synthesis inhibitor employed in our experiments as a representative unrelated cytotoxic agent.

Furthermore, we found that EGCG inhibited global ubiquitination in cells. Previously, EGCG treatment has shown upregulation of the expression of the E3 ligase RNF216 and thus increases ubiquitination and degradation of one of its substrates, the Toll-like receptor 4 (Kumazoe et al. 2017). However, this work was conducted in macrophages at a relatively low concentration of EGCG with long treatment duration, conditions that may preclude inhibition of Ubal in the cells (particularly since, with a single treatment over longer time scales, EGCG would become extensively degraded and metabolized to simpler products), but which results in increased expression of RNF216 and so enhanced ubiquitination of its specific substrates.

While inhibition of Ubal and ubiquitination may account for part of EGCG's overall activity in cells but EGCG inhibits various other cellular pathways as well. The pleiotropic activity profiles are not uncommon for bioactive small molecules and often it is indeed the felicitous combination of multiple targets inhibited that is the basis of preventive or therapeutic efficacy of a drug.

The "co-evolution" of natural products with proteins means that they intrinsically have favorable protein-binding properties. It can also present challenges in terms of selectivity between targets, as many bind conserved motifs in proteins. However, the generation of structures derived from or inspired by specific natural products, synthetically or semisynthetically, could improve selectivity for one protein over another. Such efforts could be guided by comparative SAR studies across different systems.

We tested EGCG and its analogs which are differing in constitution and stereochemistry and an informative multi-assay SAR picture has emerged (summarized with structures in 
Figure 23). The EGCG-related molecules showed a divergence of diferent SAR profiles, with the comparative activity patterns falling into the following four groupings: (1) catechin gallates (EGCG and ECG), which show very good correspondence between activity profiles in different assays, being inhibitory in the in vitro biochemical (PCNA ubiquitination and Uba1 ubiquitin thioester formation) and cellular assays (cell viability — with negative effects mitigated by overexpression of Ubal or ubiquitin); (2) simple unesterifed catechins, which display no (EC and Cat) or weak (EGC) activity in the assays; (3) longer-chain alkyl gallates (OG and DG), which are active in all the assays, with their cytotoxic effects being mitigated in cells by overexpression of Ubal or ubiquitin (while both the short-chain alkyl gallate PG and free GA itself are inactive in the biochemical assays and their negative efects on cell viability are unafected by Uba1 or ubiquitin overexpression); or (4) Myr and DM, which have potent (Myr) or weak (DM) activity in the biochemical assays and only weak activity against cell survival, with Uba1 or ubiquitin overexpression reducing the sensitivity of cells to these compounds.

All the compounds that exhibited activity in the in vitro PCNA ubiquitination and Uba1 ubiquitin thioester formation experiments also had cytostatic/cytotoxic effects that were mitigated with the overexpression of Uba1, ubiquitin, or both. This suggests that all the bioactive compounds were also binding Ubal and/or ubiquitin in the cell and that inhibition of ubiquitination at that level is relevant to the physiological activity of all these compounds. However, it is possible and indeed likely that the different structural classes of bioactive compounds, while each targeting some site on Uba1 and/or ubiquitin itself are also mechanistically distinct.

The potent inhibitory activity of the catechin gallates against the ubiquitination cascade appears to require a composite structure of both catechin and galloyl moieties. EGCG is an ester of EGC and GA, while ECG is an ester of EC and GA. Free EGC itself has weak 
activity in the biochemical assays, while free GA is inactive, as is free EC. It is known that galloylation also strongly influences various other bioactivities of catechins and other natural products (Karas, Ulrichová, and Valentová 2017). Furthermore, the 5'-OH of the B ring on the catechin skeleton of EGCG seems to play a role in the activity, possibly through hydrogen bonding with Uba1, since ECG, which lacks this hydroxyl group, has slightly diminished biochemical activity. Similarly, free EGC by itself still possesses some activity, while EC does not, again demonstrating the significance of the B-ring 5'$\mathrm{OH}$.

The mechanism of action of the longer-chain alkyl gallates (OG and DG) in inhibiting ubiquitination may be distinct from that of the catechin gallates and Myr (and its formal hydrogenation product DM). OG and DG, both esters of n-alkanols (of length $\mathrm{C} 8$ and C12, respectively) and GA, are amphiphiles with a polar "head" and straight-chain hydrophobic "tail." They may have detergent-like local-denaturing effects upon binding, consistent with the increasing inhibitory activity in the biochemical assays with longer alkyl chain, with the order of potency being DG $>$ OG $\gg$ PG. They exhibit high inherent variability in the biochemical experiments and DG, in particular, displays large divergence in potency between the PCNA ubiquitination and Ubal ubiquitin thioester formation assays (Supplementary Table 2). These results suggest that, unlike the catechin gallates and Myr, the alkyl gallates may weakly inhibit multiple components of the cascade in the PCNA ubiquitination assay and without a single specific recognition interaction, with less of the more straightforward drug-like behavior against Uba1 exhibited by the other bioactive compound classes.

Myr likely also has a unique mechanism of action. Myr and DM are both ketone carbonyl compounds and they do not have galloyl moiety, this may be key to their activity different from catechin gallates. Myr potently inhibits thioester formation whether pre-incubated 
with Ubal alone or ubiquitin alone before the addition of other reaction components, unlike EGCG. These results suggest either that Myr binds Ubal non-competitively with ATP and ubiquitin or that Myr binds ubiquitin directly, in either case inhibiting the formation of the Uba1 ubiquitin thioester by a mechanism that is distinct from EGCG. Myr and DM are both ketone carbonyl compounds and this may be key to their activity.

The strong activity of Myr may be tied to its Michael acceptor ( $\alpha, \beta$-unsaturated carbonyl) functionality, a potentially reactive electrophile ( $\beta$ carbon of the $\alpha, \beta$-unsaturated carbonyl in Myr, Figure 23) susceptible to attack by nucleophile on Ubal(such as the side-chain thiol of its active-site cysteine, normally involved in the reaction with ubiquitin to form the Uba1 ubiquitin thioester adduct). In DM, which lacks an $\alpha, \beta$-unsaturated carbonyl, is much more weakly active for ubiquitination and Ubal ubiquitin thioester formation than Myr, consistent with such a mechanism.

The Michael reaction is often irreversible, we tested whether Myr irreversibly inhibits Ubal and/or ubiquitin function or not. We found that Myr, like EGCG, appears to inhibit ubiquitination reversibly. A covalent though the reversible reaction is still not unlikely to be involved. The electronic and steric effects of the substitution pattern on the $\alpha$ and $\beta$ carbons, as well as the nature of the incoming nucleophile on the target, may make Michael addition to Myr reversible through $\beta$ elimination. Indeed, such chemical parameters are known to influence reactivity and reversibility in Michael acceptors, with numerous examples of reversible bioactive Michael acceptor-containing compounds in the literature (H. Johansson 2012; Jackson et al. 2017).

The Michael reaction is a 1,4-addition (conjugate addition) reaction, another reaction typical of these systems is 1,2-addition (direct addition), where the nucleophile reacts with the carbonyl carbon instead of the $\beta$ carbon. The direct addition is kinetically favored, 
though not thermodynamically over conjugate addition. It is generally reversible for weakly basic nucleophiles, such as thiols, alcohols and amines, the most common nucleophiles present in proteins. Therefore, a reversible covalent protein-small molecule species could also be the result of the direct addition of a protein nucleophile to the ketone carbonyl on Myr, a reaction also available to DM. Both reversible Michael addition and direct addition are possibilities to explain why the $\alpha, \beta$-unsaturated carbonyl appears important for activity in Myr and these candidate mechanisms are not mutually exclusive. In contrast, in DM, only a direct addition to the ketone is possible, which could conceivably explain its weak residual activity. This is consistent with the observation that Cat, which differs from DM only in lacking the ketone, is entirely inactive. Thus, both conjugate and direct addition may be involved in Myr's inhibitory activity, with conjugate addition likely playing the larger role.

However, it is also important to consider the structural explanations that do not involve any covalent reaction. The compounds differ geometrically besides electronically. Myr possesses a planar $\alpha, \beta$-unsaturated system, while DM has tetrahedral $\alpha$ and $\beta$ centers. Therefore, Myr's mechanism of action could involve reversible covalent reaction(s), noncovalent inhibitory interaction between small molecule and protein, or a combination of these non-mutually exclusive mechanisms.

After SAR studies, we further validated the assays with EGCG and its analogs in our Alpha based site-specific PCNA ubiquitination assays (Figure 31 and 31). We performed dose-response experiments with the Alpha assays for PCNA ubiquitination and Ubal ubiquitin thioester formation. The structure-activity relationships discussed above were similar trends in relative calculated $\mathrm{IC}_{50}$ values for each of the bioactive compounds. 
Green tea polyphenols, particularly EGCG, have widely acknowledged potential as preventive or therapeutic agents against a range of cancers and other disease states. Inhibition of Ubal and ubiquitination, recognized as promising loci for therapeutic intervention in many of the same diseases, may account for part of EGCG's overall biological effects and so the present work may help lead to a better understanding of EGCG's health-beneficial properties. Moreover, the fact that EGCG and its analogs fall into distinct mechanistic subclasses that are rather cleanly correlated to structure opens up exciting possibilities for future research. Each series of the bioactive small molecule identified represents a different first-in-class type of chemical modulator of ubiquitination, a hierarchical cascade of reactions that has drawn great interest from both the basic research and drug discovery communities. In the future, improved specificity and selectivity may arise from the assessment of further natural, semisynthetic, or synthetic congeners of the pharmacophore types delineated in the present study, yielding valuable therapeutic drug leads and tools from these different structural and mechanistic sets of molecules. 


\section{Acknowledgment}

First of all, I would like to thank my supervisor Prof. Lajos Haracska for providing me an opportunity to work in his laboratory. He was always there to help me during my Ph.D. studies period, be it related to work or motivation. Similarly, I would like to thank and express my gratitude to Dr. Gabriel Fenteany who guided me and supervised me throughout the project. I appreciate his support and constructive suggestions which have contributed greatly to the improvement of my scientific skills. His friendly supervision and expert advice have been invaluable throughout all stages of the project.

I would also like to thank all the lab members of the HCEMM-BRC Mutagenesis and Carcinogenesis Research Group, Delta Bio 2000 company and the members of Dr. Ildikó Unk's laboratory for their support and help throughout my Ph.D.; especially Róbert Tóth, Lili Hegedüs, Kata Dudás, Ernő Kiss, Kata Katalin Illésné Kovács, Gaurav Sharma, Lajos Pintér, Icu Nótári Péterné and Gabriella Tick for their intellectual and technical support throughout my Ph.D. project.

I extend my thanks to Prof. Tamas Martinek and Dr. Edit Weber from the Department of Medicinal Chemistry, University of Szeged, Hungary for their successful scientific collaborations and publications.

I would like to thank especially Dr. Éva Bálint and Dr. Gerda Szakonyi for accepting my request to review my thesis for home defense.

I always feel blessed to work under the guidance of smart, knowledgeable and very hardworking scientists from my previous lab where I worked as a research trainee under Dr. Madhulika Srivastava, Dr. Manisha Jalan and Abhilasha Kanaujia from the National 
Institute of Immunology, Delhi, India. Their dedication to science inspired me to pursue a career in science. I am also grateful to Dr. Sharmila Basu Modak from the Department of Zoology, Delhi University, Delhi India, and especially Dr. Vijayachandra for providing constant guidance and support throughout my B.Sc, M.SC and Ph.D. study period.

Last but not the least, I would like to acknowledge the support I received from the administrative staff of the Institute of Genetics, Biological Research Centre, University of Szeged, Tempus Public Foundation and University Grant Commission. I appreciate the friendship and the opportunity to spend a great time with my Hungarian and nonHungarian friends who made my stay here memorable especially Tamás Marik, Chetna Tyagi, Neha Sahu, Maitryee Pathak, Csaba Gál, Payal Chakraborty, Mátron Zsolt Enyedi, Zoltán Szabó and David Li.

My deepest gratitude to my parents and brother for their love, understanding and encouragement throughout my Ph.D. 


\section{References}

Aggarwal, Bharat B., and Shishir Shishodia. 2006. "Molecular Targets of Dietary Agents for Prevention and Therapy of Cancer." Biochemical Pharmacology. Elsevier Inc. https://doi.org/10.1016/j.bcp.2006.02.009.

An, Heeseon, and Alexander V. Statsyuk. 2013. "Development of Activity-Based Probes for Ubiquitin and Ubiquitin-like Protein Signaling Pathways.” Journal of the American Chemical Society 135 (45): 16948-62. https://doi.org/10.1021/ja4099643.

Becker, Walter, Krishna Chaitanya Bhattiprolu, Nina Gubensäk, and Klaus Zangger. 2018. "Investigating Protein-Ligand Interactions by Solution Nuclear Magnetic Resonance Spectroscopy." ChemPhysChem. https://doi.org/10.1002/cphc.201701253.

Bienko, Marzena, Catherine M. Green, Nicola Crosetto, Fabian Rudolf, Grzegorz Zapart, Barry Coull, Patricia Kannouche, et al. 2005. "Biochemistry: UbiquitinBinding Domains in Y-Family Polymerases Regulate Translesion Synthesis.” Science 310 (5755): 1821-24. https://doi.org/10.1126/science.1120615.

Boehm, E. M., M. S. Gildenberg, and M. T. Washington. 2016. "The Many Roles of PCNA in Eukaryotic DNA Replication.” In Enzymes. https://doi.org/10.1016/bs.enz.2016.03.003.

Bont, Rinne De, and Nik van Larebeke. 2004. "Endogenous DNA Damage in Humans: A Review of Quantitative Data." Mutagenesis. https://doi.org/10.1093/mutage/geh025.

Branzei, Dana. 2011. “Ubiquitin Family Modifications and Template Switching.” FEBS 
Letters. https://doi.org/10.1016/j.febslet.2011.04.053.

Chakrawarti, Leewanshi, Rishab Agrawal, Shweta Dang, Sanjay Gupta, and Reema Gabrani. 2016. “Therapeutic Effects of EGCG: A Patent Review.” Expert Opinion on Therapeutic Patents. https://doi.org/10.1080/13543776.2016.1203419.

Cho, A. R., J. H. Kim, D. E. Lee, J. S. Lee, U. W. Jung, E. J. Bak, Y. J. Yoo, W. G. Chung, and S. H. Choi. 2013. "The Effect of Orally Administered Epigallocatechin-3-Gallate on Ligature-Induced Periodontitis in Rats.” Journal of Periodontal Research 48 (6): 781-89. https://doi.org/10.1111/jre.12071.

Chu, Chenyu, Jia Deng, Yi Man, and Yili Qu. 2017. “Green Tea Extracts Epigallocatechin-3-Gallate for Different Treatments.” BioMed Research International. Hindawi Limited. https://doi.org/10.1155/2017/5615647.

Einsele, Hermann. 2014. “Bortezomib.” Recent Results in Cancer Research 201: 32545. https://doi.org/10.1007/978-3-642-54490-3_20.

Fenteany, Gabriel, Paras Gaur, Gaurav Sharma, Lajos Pintér, Ernő Kiss, and Lajos Haracska. 2020. "Robust High-Throughput Assays to Assess Discrete Steps in Ubiquitination and Related Cascades.” BMC Molecular and Cell Biology 21 (1): 21. https://doi.org/10.1186/s12860-020-00262-5.

Finkelstein, Jeff, Edwin Antony, Manju M. Hingorani, and Michael O’Donnell. 2003. "Overproduction and Analysis of Eukaryotic Multiprotein Complexes in Escherichia Coli Using a Dual-Vector Strategy.” Analytical Biochemistry 319 (1): 78-87. https://doi.org/10.1016/S0003-2697(03)00273-2.

Fousteri, Maria, and Leon H.F. Mullenders. 2008. “Transcription-Coupled Nucleotide 
Excision Repair in Mammalian Cells: Molecular Mechanisms and Biological Effects." Cell Research. https://doi.org/10.1038/cr.2008.6.

Friedberg, Errol C. 2005. "Suffering in Silence: The Tolerance of DNA Damage." Nature Reviews Molecular Cell Biology. https://doi.org/10.1038/nrm1781.

Friedman, Scott L. 1997. "Molecular Mechanisms of Hepatic Fibrosis and Principles of Therapy." Journal of Gastroenterology. Springer Tokyo. https://doi.org/10.1007/BF02934504.

—. 1999. "Cytokines and Fibrogenesis.” Seminars in Liver Disease. Thieme Medical Publishers, Inc. https://doi.org/10.1055/s-2007-1007105.

Friedman, Scott L., and Meena B. Bansal. 2006. "Reversal of Hepatic Fibrosis - Fact or Fantasy?" Hepatology. https://doi.org/10.1002/hep.20974.

Gali, Himabindu, Szilvia Juhasz, Monika Morocz, Ildiko Hajdu, Karoly Fatyol, Valeria Szukacsov, Peter Burkovics, and Lajos Haracska. 2012. "Role of SUMO Modification of Human PCNA at Stalled Replication Fork." Nucleic Acids Research 40 (13): 6049-59. https://doi.org/10.1093/nar/gks256.

Gallo, David, and Grant W. Brown. 2019. "Post-Replication Repair: Rad5/HLTF Regulation, Activity on Undamaged Templates, and Relationship to Cancer." Critical Reviews in Biochemistry and Molecular Biology. Taylor and Francis Ltd. https://doi.org/10.1080/10409238.2019.1651817.

Gangavarapu, V., L. Haracska, I. Unk, R. E. Johnson, S. Prakash, and L. Prakash. 2006. "Mms2-Ubc13-Dependent and -Independent Roles of Rad5 Ubiquitin Ligase in Postreplication Repair and Translesion DNA Synthesis in Saccharomyces 
Cerevisiae." Molecular and Cellular Biology 26 (20): 7783-90.

https://doi.org/10.1128/mcb.01260-06.

Garg, Parie, Carrie M. Stith, Nasim Sabouri, Erik Johansson, and Peter M. Burgers. 2004. "Idling by DNA Polymerase $\delta$ Maintains a Ligatable Nick during LaggingStrand DNA Replication." Genes and Development 18 (22): 2764-73. https://doi.org/10.1101/gad.1252304.

Gomes, Xavier V., and Peter M.J. Burgers. 2000. "Two Modes of FEN1 Binding to PCNA Regulated by DNA.” EMBO Journal 19 (14): 3811-21. https://doi.org/10.1093/emboj/19.14.3811.

Groen, Ewout J.N., and Thomas H. Gillingwater. 2015. "UBA1: At the Crossroads of Ubiquitin Homeostasis and Neurodegeneration.” Trends in Molecular Medicine. Elsevier Ltd. https://doi.org/10.1016/j.molmed.2015.08.003.

Guan, Junhong, Shuyu Yu, and Xiaofeng Zheng. 2018. "NEDDylation Antagonizes Ubiquitination of Proliferating Cell Nuclear Antigen and Regulates the Recruitment of Polymerase $\eta$ in Response to Oxidative DNA Damage." Protein and Cell 9 (4): 365-79. https://doi.org/10.1007/s13238-017-0455-x.

H. Johansson, Martin. 2012. "Reversible Michael Additions: Covalent Inhibitors and Prodrugs." Mini-Reviews in Medicinal Chemistry. https://doi.org/10.2174/13895575112091330.

Haracska, L., C. A. Torres-Ramos, R. E. Johnson, S. Prakash, and L. Prakash. 2004. “Opposing Effects of Ubiquitin Conjugation and SUMO Modification of PCNA on Replicational Bypass of DNA Lesions in Saccharomyces Cerevisiae.” Molecular and Cellular Biology 24 (10): 4267-74. https://doi.org/10.1128/mcb.24.10.4267- 
4274.2004.

Haracska, Lajos, Ildiko Unk, Louise Prakash, and Satya Prakash. 2006. "Ubiquitylation of Yeast Proliferating Cell Nuclear Antigen and Its Implications for Translesion DNA Synthesis." Proceedings of the National Academy of Sciences of the United States of America. https://doi.org/10.1073/pnas.0510924103.

Helleday, Thomas, Justin Lo, Dik C. van Gent, and Bevin P. Engelward. 2007. "DNA Double-Strand Break Repair: From Mechanistic Understanding to Cancer Treatment.” DNA Repair. https://doi.org/10.1016/j.dnarep.2007.02.006.

Higashi, Nobuhiko, Motoyuki Kohjima, Marie Fukushima, Satoshi Ohta, Kazuhiro Kotoh, Munechika Enjoji, Naoya Kobayashi, and Makoto Nakamuta. 2005. "Epigallocatechin-3-Gallate, a Green-Tea Polyphenol, Suppresses Rho Signaling in TWNT-4 Human Hepatic Stellate Cells.” Journal of Laboratory and Clinical Medicine 145 (6): 316-22. https://doi.org/10.1016/j.lab.2005.03.017.

Hoege, Carsten, Boris Pfander, George Lucian Moldovan, George Pyrowolakis, and Stefan Jentsch. 2002. "RAD6-Dependent DNA Repair Is Linked to Modification of PCNA by Ubiquitin and SUMO.” Nature 419 (6903): 135-41. https://doi.org/10.1038/nature00991.

Hoitsma, Nicole M., Amy M. Whitaker, Matthew A. Schaich, Mallory R. Smith, Max S. Fairlamb, and Bret D. Freudenthal. 2020. "Structure and Function Relationships in Mammalian DNA Polymerases.” Cellular and Molecular Life Sciences. Springer. https://doi.org/10.1007/s00018-019-03368-y.

Hong, Ji Youn, Jeyoung Yon, Jung Seok Lee, In Kyeong Lee, Cheryl Yang, Min Soo Kim, Seong Ho Choi, and Ui Won Jung. 2015. "Effects of Epigallocatechin-3- 
Gallate on the Healing of Extraction Sockets with a Periapical Lesion: A Pilot Study in Dogs.” Journal of Biomedical Materials Research - Part B Applied Biomaterials 103 (4): 727-34. https://doi.org/10.1002/jbm.b.33238.

Hong, Jiyong, and Hendrik Luesch. 2012. "Largazole: From Discovery to BroadSpectrum Therapy.” Nat. Prod. Rep. 29 (4): 449-56. https://doi.org/10.1039/c2np00066k.

Hsieh, Peggy, and Kazuhiko Yamane. 2008. "DNA Mismatch Repair: Molecular Mechanism, Cancer, and Ageing." Mechanisms of Ageing and Development 129 (7-8): 391-407. https://doi.org/10.1016/j.mad.2008.02.012.

Hyer, Marc L., Michael A. Milhollen, Jeff Ciavarri, Paul Fleming, Tary Traore, Darshan Sappal, Jessica Huck, et al. 2018. "A Small-Molecule Inhibitor of the Ubiquitin Activating Enzyme for Cancer Treatment." Nature Medicine 24 (2): 186-93. https://doi.org/10.1038/nm.4474.

Jackson, Paul A., John C. Widen, Daniel A. Harki, and Kay M. Brummond. 2017. "Covalent Modifiers: A Chemical Perspective on the Reactivity of $\alpha, \beta$-Unsaturated Carbonyls with Thiols via Hetero-Michael Addition Reactions." Journal of Medicinal Chemistry. https://doi.org/10.1021/acs.jmedchem.6b00788.

Jena, N. R. 2012. "DNA Damage by Reactive Species: Mechanisms, Mutation and Repair.” In Journal of Biosciences. https://doi.org/10.1007/s12038-012-9218-2. Jiricny, Josef. 2006. “The Multifaceted Mismatch-Repair System.” Nature Reviews Molecular Cell Biology. https://doi.org/10.1038/nrm1907.

Johnson, Lianna M., Michael Snyder, Lucy M.S. Chang, Ronald W. Davis, and Judith 
L. Campbell. 1985. "Isolation of the Gene Encoding Yeast DNA Polymerase I." Cell. https://doi.org/10.1016/0092-8674(85)90042-X.

Johnson, Robert E., Roland Klassen, Louise Prakash, and Satya Prakash. 2015. “A Major Role of DNA Polymerase $\delta$ in Replication of Both the Leading and Lagging DNA Strands.” Molecular Cell 59 (2): 163-75. https://doi.org/10.1016/j.molcel.2015.05.038.

Kamata, Hideaki, and Hajime Hirata. 1999. "Redox Regulation of Cellular Signalling." Cellular Signalling. https://doi.org/10.1016/S0898-6568(98)00037-0.

Kanao, Rie, and Chikahide Masutani. 2017. "Regulation of DNA Damage Tolerance in Mammalian Cells by Post-Translational Modifications of PCNA.” Mutation Research - Fundamental and Molecular Mechanisms of Mutagenesis. Elsevier B.V. https://doi.org/10.1016/j.mrfmmm.2017.06.004.

Karas, Daniel, Jitka Ulrichová, and Kateřina Valentová. 2017. “Galloylation of Polyphenols Alters Their Biological Activity." Food and Chemical Toxicology. https://doi.org/10.1016/j.fct.2017.04.021.

Khan, Naghma, Farrukh Afaq, Mohammad Saleem, Nihal Ahmad, and Hasan Mukhtar. 2006. "Targeting Multiple Signaling Pathways by Green Tea Polyphenol (-)Epigallocatechin-3-Gallate.” Cancer Research. https://doi.org/10.1158/00085472.CAN-05-3636.

Kitamura, Mineaki, Tomoya Nishino, Yoko Obata, Akira Furusu, Yoshitaka Hishikawa, Takehiko Koji, and Shigeru Kohno. 2012. “Epigallocatechin Gallate Suppresses Peritoneal Fibrosis in Mice.” Chemico-Biological Interactions 195 (1): 95-104. https://doi.org/10.1016/j.cbi.2011.11.002. 
Kostopoulos, L., and T. Karring. 1994. “Augmentation of the Rat Mandible Using Guided Tissue Regeneration.” Clinical Oral Implants Research 5 (2): 75-82. https://doi.org/10.1034/j.1600-0501.1994.050203.x.

Krishna, Talluru S.R., Xiang Peng Kong, Sonja Gary, Peter M. Burgers, and John Kuriyan. 1994. "Crystal Structure of the Eukaryotic DNA Polymerase Processivity Factor PCNA.” Cell 79 (7): 1233-43. https://doi.org/10.1016/00928674(94)90014-0.

Kumazoe, Motofumi, Yuki Nakamura, Mai Yamashita, Takashi Suzuki, Kanako Takamatsu, Yuhui Huang, Jaehoon Bae, et al. 2017. “Green Tea Polyphenol Epigallocatechin-3-Gallate Suppresses Toll-like Receptor 4 Expression via upRegulation of E3 Ubiquitin-Protein Ligase RNF216.” Journal of Biological Chemistry. https://doi.org/10.1074/jbc.M116.755959.

Lee, Yoo Hyun, Jieun Kwak, Hyo Kyoung Choi, Kyung Chul Choi, Sunoh Kim, Jeongmin Lee, Woojin Jun, Hyun Jin Park, and Ho Geun Yoon. 2012. "EGCG Suppresses Prostate Cancer Cell Growth Modulating Acetylation of Androgen Receptor by Anti-Histone Acetyltransferase Activity.” International Journal of Molecular Medicine 30 (1): 69-74. https://doi.org/10.3892/ijmm.2012.966.

Lehmann, Alan R., Atsuko Niimi, Tomoo Ogi, Stephanie Brown, Simone Sabbioneda, Jonathan F. Wing, Patricia L. Kannouche, and Catherine M. Green. 2007. "Translesion Synthesis: Y-Family Polymerases and the Polymerase Switch." DNA Repair 6 (7): 891-99. https://doi.org/10.1016/j.dnarep.2007.02.003.

Leung, Wendy, Ryan M. Baxley, George Lucian Moldovan, and Anja Katrin Bielinsky. 2019. "Mechanisms of DNA Damage Tolerance: Post-Translational Regulation of 
PCNA.” Genes. MDPI AG. https://doi.org/10.3390/genes10010010.

Li, Guang Xun, Yu Kuo Chen, Zhe Hou, Hang Xiao, Huanyu Jin, Gary Lu, Mao Jung Lee, et al. 2010. "Pro-Oxidative Activities and Dose-Response Relationship of (-)Epigallocatechin-3-Gallate in the Inhibition of Lung Cancer Cell Growth: A Comparative Study in Vivo and in Vitro." Carcinogenesis 31 (5): 902-10. https://doi.org/10.1093/carcin/bgq039.

Lin, Jen Kun, Yu Chih Liang, Yu Li Lin, and Chi Tang Ho. 2000. "Cancer Prevention Properties of Tea: Biochemical Mechanisms.” ACS Symposium Series 754: 78-86. https://doi.org/10.1021/bk-2000-0754.ch010.

Lin, Jia Ren, Michelle K. Zeman, Jia Yun Chen, Muh Ching Yee, and Karlene A. Cimprich. 2011. "SHPRH and HLTF Act in a Damage-Specific Manner to Coordinate Different Forms of Postreplication Repair and Prevent Mutagenesis.” Molecular Cell 42 (2): 237-49. https://doi.org/10.1016/j.molcel.2011.02.026.

Lindahl, T., and D. E. Barnes. 2000. "Repair of Endogenous DNA Damage.” In Cold Spring Harbor Symposia on Quantitative Biology, 65:127-33. https://doi.org/10.1101/sqb.2000.65.127.

Livneh, Zvi, Omer Ziv, and Sigal Shachar. 2010. "Multiple Two-Polymerase Mechanisms in Mammalian Translesion DNA Synthesis.” Cell Cycle. Taylor and Francis Inc. https://doi.org/10.4161/cc.9.4.10727.

Longley, Matthew J., Andrew J. Pierce, and Paul Modrich. 1997. "DNA Polymerase $\delta$ Is Required for Human Mismatch Repair in Vitro.” Journal of Biological Chemistry 272 (16): 10917-21. https://doi.org/10.1074/jbc.272.16.10917. 
Macheret, Morgane, and Thanos D. Halazonetis. 2015. "DNA Replication Stress as a Hallmark of Cancer.” Annual Review of Pathology: Mechanisms of Disease 10 (1): 425-48. https://doi.org/10.1146/annurev-pathol-012414-040424.

Majka, Jerzy, and Peter M.J. Burgers. 2004. "The PCNA-RFC Families of DNA Clamps and Clamp Loaders.” Progress in Nucleic Acid Research and Molecular Biology 78: 227-60. https://doi.org/10.1016/S0079-6603(04)78006-X.

Mayer, M., and B. Meyer. 2001. “Group Epitope Mapping by Saturation Transfer Difference NMR to Identify Segments of a Ligand in Direct Contact with a Protein Receptor." Journal of the American Chemical Society. https://doi.org/10.1021/ja0100120.

Mayer, Moriz, and Bernd Meyer. 1999. "Characterization of Ligand Binding by Saturation Transfer Difference NMR Spectroscopy." Angewandte Chemie International Edition. https://doi.org/10.1002/(SICI)15213773(19990614)38:12<1784::AID-ANIE1784>3.0.CO;2-Q.

Mazouzi, Abdelghani, Georgia Velimezi, and Joanna I. Loizou. 2014. "DNA Replication Stress: Causes, Resolution and Disease." Experimental Cell Research. https://doi.org/10.1016/j.yexcr.2014.09.030.

Meyer, Bernd, and Thomas Peters. 2003. "NMR Spectroscopy Techniques for Screening and Identifying Ligand Binding to Protein Receptors.” Angewandte Chemie - International Edition. https://doi.org/10.1002/anie.200390233.

Moldovan, George Lucian, Boris Pfander, and Stefan Jentsch. 2007. "PCNA, the Maestro of the Replication Fork." Cell. https://doi.org/10.1016/j.cell.2007.05.003. 
Monda, Julie K., and Iain M. Cheeseman. 2018. "Dynamic Regulation of Dynein Localization Revealed by Small Molecule Inhibitors of Ubiquitination Enzymes." Open Biology 8 (9). https://doi.org/10.1098/rsob.180095.

Moses, Michael A., Ellen C. Henry, William A. Ricke, and Thomas A. Gasiewicz. 2015. "The Heat Shock Protein 90 Inhibitor, (-)-Epigallocatechin Gallate, Has Anticancer Activity in a Novel Human Prostate Cancer Progression Model.” Cancer Prevention Research 8 (3): 249-57. https://doi.org/10.1158/19406207.CAPR-14-0224.

N., Asli, Sergio C., and Taosheng Che. 2013. "Data Analysis Approaches in High Throughput Screening." In Drug Discovery. InTech. https://doi.org/10.5772/52508.

Nagai, Kaoru, Min Hai Jiang, Junichi Hada, Tetsu Nagata, Yukio Yajima, Satoshi Yamamoto, and Tomoyuki Nishizaki. 2002. “(-)-Epigallocatechin Gallate Protects against NO Stress-Induced Neuronal Damage after Ischemia by Acting as an AntiOxidant.” Brain Research 956 (2): 319-22. https://doi.org/10.1016/S00068993(02)03564-3.

Nakagawa, Hiroshi, Keiji Hasumi, Je Tae Woo, Kazuo Nagai, and Masaaki Wachi. 2004. "Generation of Hydrogen Peroxide Primarily Contributes to the Induction of Fe(II)-Dependent Apoptosis in Jurkat Cells by (-)-Epigallocatechin Gallate.” Carcinogenesis 25 (9): 1567-74. https://doi.org/10.1093/carcin/bgh168.

Nakamuta, Makoto, Nobuhiko Higashi, Motoyuki Kohjima, Marie Fukushima, Satoshi Ohta, Kazuhiro Kotoh, Naoya Kobayashi, and Munechika Enjoji. 2005. “Epigallocatechin-3-Gallate, a Polyphenol Component of Green Tea, Suppresses Both Collagen Production and Collagenase Activity in Hepatic Stellate Cells." 
International Journal of Molecular Medicine 16 (4): 677-81.

https://doi.org/10.3892/ijmm.16.4.677.

Negrini, Simona, Vassilis G. Gorgoulis, and Thanos D. Halazonetis. 2010. “Genomic Instability an Evolving Hallmark of Cancer.” Nature Reviews Molecular Cell Biology. https://doi.org/10.1038/nrm2858.

Okazaki, T., and R. Okazaki. 1969. "Mechanism of DNA Chain Growth. IV. Direction of Synthesis of T4 Short DNA Chains as Revealed by Exonucleolytic Degradation." Proceedings of the National Academy of Sciences of the United States of America. https://doi.org/10.1073/pnas.64.4.1242.

Parikh, Sudip S., Clifford D. Mol, Geir Slupphaug, Sangeeta Bharati, Hans E. Krokan, and John A. Tainer. 1998. "Base Excision Repair Initiation Revealed by Crystal Structures and Binding Kinetics of Human Uracil-DNA Glycosylase with DNA.” EMBO Journal 17 (17): 5214-26. https://doi.org/10.1093/emboj/17.17.5214.

Park, Jung Mi, Seung Wook Yang, Kyung Ryun Yu, Seung Hyun Ka, Seong Won Lee, Jae Hong Seol, Young Joo Jeon, and Chin Ha Chung. 2014. "Modification of PCNA by ISG15 Plays a Crucial Role in Termination of Error-Prone Translesion DNA Synthesis." Molecular Cell 54 (4): 626-38. https://doi.org/10.1016/j.molcel.2014.03.031.

Parker, Joanne L., and Helle D. Ulrich. 2009. "Mechanistic Analysis of PCNA PolyUbiquitylation by the Ubiquitin Protein Ligases Rad18 and Rad5." EMBO Journal 28 (23): 3657-66. https://doi.org/10.1038/emboj.2009.303.

Pellegrini, Luca. 2012. “The Pol A-Primase Complex.” In The Eukaryotic Replisome: A Guide to Protein Structure and Function, 62:135-56. https://doi.org/10.1007/978- 
94-007-4572-8.

Pikor, Larissa, Kelsie Thu, Emily Vucic, and Wan Lam. 2013. "The Detection and Implication of Genome Instability in Cancer." Cancer and Metastasis Reviews 32 (3-4): 341-52. https://doi.org/10.1007/s10555-013-9429-5.

Powers, Kyle T., and M. Todd Washington. 2018. "Eukaryotic Translesion Synthesis: Choosing the Right Tool for the Job.” DNA Repair. Elsevier B.V. https://doi.org/10.1016/j.dnarep.2018.08.016.

Sabetkar, Mojhgan, Sylvia Y. Low, Nickolas J. Bradley, Michael Jacobs, Khalid M. Naseem, and K. Richard Bruckdorfer. 2008. "The Nitration of Platelet Vasodilator Stimulated Phosphoprotein Following Exposure to Low Concentrations of Hydrogen Peroxide.” Platelets 19 (4): 282-92. https://doi.org/10.1080/09537100801915142.

Sakagami, H., H. Arakawa, M. Maeda, K. Satoh, T. Kadofuku, K. Fukuchi, and K. Gomi. 2001. "Production of Hydrogen Peroxide and Methionine Sulfoxide by Epigallocatechin Gallate and Antioxidants.” Anticancer Research 21 (4 A): 263341.

Sakata, Ryuichiro, Takato Ueno, Toru Nakamura, Masaharu Sakamoto, Takuji Torimura, and Michio Sata. 2004. “Green Tea Polyphenol Epigallocatechin-3Gallate Inhibits Platelet-Derived Growth Factor-Induced Proliferation of Human Hepatic Stellate Cell Line LI90.” Journal of Hepatology 40 (1): 52-59. https://doi.org/10.1016/S0168-8278(03)00477-X.

Sale, Julian E. 2013. "Translesion DNA Synthesis and Mutagenesis in Eukaryotes." Cold Spring Harbor Perspectives in Biology 5 (3). 
https://doi.org/10.1101/cshperspect.a012708.

Sancar, A. 1996. "DNA Excision Repair.” Annual Review of Biochemistry 65 (1): $43-$ 81. https://doi.org/10.1146/annurev.biochem.65.1.43.

Schneider, Caroline A., Wayne S. Rasband, and Kevin W. Eliceiri. 2012. "NIH Image to ImageJ: 25 Years of Image Analysis.” Nature Methods. https://doi.org/10.1038/nmeth.2089.

Sekizawa, Ryuichi, Souichi Ikeno, Hikaru Nakamura, Hiroshi Naganawa, Susumu Matsui, Hironobu Iinuma, and Tomio Takeuchi. 2002. "Panepophenanthrin, from a Mushroom Strain, a Novel Inhibitor of the Ubiquitin-Activating Enzyme.” J. Nat. Prod. 65 (10): 1491-93. https://doi.org/10.1021/np020098q.

Shcherbakova, Polina V., and Iwona J. Fijalkowska. 2006. "Translesion Synthesis DNA Polymerases and Control of Genome Stability.” Frontiers in Bioscience. https://doi.org/10.2741/1985.

Shen, Zhiyuan. 2011. “Genomic Instability and Cancer: An Introduction.” Journal of Molecular Cell Biology. https://doi.org/10.1093/jmcb/mjq057.

Shin, Y. S., J. Y. Seo, S. H. Oh, J. H. Kim, S. T. Kim, Y. B. Park, and H. S. Moon. 2014. "The Effects of ErhBMP-2-/EGCG-Coated BCP Bone Substitute on Dehiscence around Dental Implants in Dogs.” Oral Diseases 20 (3): 281-87. https://doi.org/10.1111/odi.12109.

Singh, Anil K, Sadiq Umar, Sharayah Riegsecker, Mukesh Chourasia, and Salahuddin Ahmed. 2016. "Regulation of TAK1 Activation by Epigallocatechin-3-Gallate in RA Synovial Fibroblasts: Suppression of K63-Linked Autoubiquitination of 
TRAF6." Arthritis Rheumatol. 68 (2): 347-58. https://doi.org/10.1002/art.39447.

Singh, Rashmi, Nahid Akhtar, and Tariq M. Haqqi. 2010. “Green Tea Polyphenol Epigallocatechi3-Gallate: Inflammation and Arthritis." Life Sciences. https://doi.org/10.1016/j.lfs.2010.04.013.

Soucy, Teresa A., Peter G. Smith, Michael A. Milhollen, Allison J. Berger, James M. Gavin, Sharmila Adhikari, James E. Brownell, et al. 2009. “An Inhibitor of NEDD8-Activating Enzyme as a New Approach to Treat Cancer." Nature 458 (7239): 732-36. https://doi.org/10.1038/nature07884.

Stelter, Philipp, and Helle D. Ulrich. 2003. "Control of Spontaneous and DamageInduced Mutagenesis by SUMO and Ubiquitin Conjugation." Nature. https://doi.org/10.1038/nature01965.

Sugimoto, K., T. Okazaki, Y. Imae, and R. Okazaki. 1969. "Mechanism of DNA Chain Growth. 3. Equal Annealing of T4 Nascent Short DNA Chains with the Separated Complementary Strands of the Phage DNA." Proceedings of the National Academy of Sciences of the United States of America. https://doi.org/10.1073/pnas.63.4.1343.

Sugimoto, K., T. Okazaki, and R. Okazaki. 1968. "Mechanism of DNA Chain Growth, II. Accumulation of Newly Synthesized Short Chains in E. Coli Infected with Ligase-Defective T4 Phages." Proceedings of the National Academy of Sciences of the United States of America. https://doi.org/10.1073/pnas.60.4.1356.

Tedeschi, E., H. Suzuki, and M. Menegazzi. 2002. "Antiinflammatory Action of EGCG, the Main Component of Green Tea, through STAT-1 Inhibition.” In Annals of the New York Academy of Sciences, 973:435-37. New York Academy of Sciences. 
https://doi.org/10.1111/j.1749-6632.2002.tb04678.x.

Tedeschi, Elisa, Marta Menegazzi, Ying Yao, Hisanori Suzuki, Ulrich Förstermann, and Hartmut Kleinert. 2004. “Green Tea Inhibits Human Inducible Nitric-Oxide Synthase Expression by Down-Regulating Signal Transducer and Activator of Transcription-1 $\alpha$ Activation.” Molecular Pharmacology 65 (1): 111-20. https://doi.org/10.1124/mol.65.1.111.

Thangapazham, Rajesh L., Anoop K. Singh, Anuj Sharma, James Warren, Jaya P. Gaddipati, and Radha K. Maheshwari. 2007. "Green Tea Polyphenols and Its Constituent Epigallocatechin Gallate Inhibits Proliferation of Human Breast Cancer Cells in Vitro and in Vivo." Cancer Letters 245 (1-2): 232-41. https://doi.org/10.1016/j.canlet.2006.01.027.

Tsukamoto, Sachiko, Hiroshi Hirota, Misako Imachi, Masahiro Fujimuro, Hiroyuki Onuki, Tomihisa Ohta, and Hideyoshi Yokosawa. 2005. "Himeic Acid A: A New Ubiquitin-Activating Enzyme Inhibitor Isolated from a Marine-Derived Fungus, Aspergillus Sp.” Bioorg. Med. Chem. Lett. 15 (1): 191-94. https://doi.org/10.1016/j.bmcl.2004.10.012.

Ungermannova, Dana, Junglim Lee, Gan Zhang, H. Garry Dallmann, Charles S. McHenry, and Xuedong Liu. 2013. "High-Throughput Screening AlphaScreen Assay for Identification of Small-Molecule Inhibitors of Ubiquitin E3 Ligase SCF Skp2-Cks1.” J. Biomol. Screen. 18 (8): 910-20.

https://doi.org/10.1177/1087057113485789.

Ungermannova, Dana, Seth J. Parker, Christopher G. Nasveschuk, Wei Wang, Bettina Quade, Gan Zhang, Robert D. Kuchta, Andrew J. Phillips, and Xuedong Liu. 2012. 
"Largazole and Its Derivatives Selectively Inhibit Ubiquitin Activating Enzyme (E1).” PLoS ONE 7 (1). https://doi.org/10.1371/journal.pone.0029208.

Unk, Ildiko, Ildikó Hajdú, András Blastyák, and Lajos Haracska. 2010. “Role of Yeast Rad5 and Its Human Orthologs, HLTF and SHPRH in DNA Damage Tolerance.” DNA Repair. https://doi.org/10.1016/j.dnarep.2009.12.013.

Unk, Ildiko, Ildikó Hajdú, Károly Fátyol, Jerard Hurwitz, Jung Hoon Yoon, Louise Prakash, Satya Prakash, and Lajos Haracska. 2008. "Human HLTF Functions as a Ubiquitin Ligase for Proliferating Cell Nuclear Antigen Polyubiquitination.” Proceedings of the National Academy of Sciences of the United States of America 105 (10): 3768-73. https://doi.org/10.1073/pnas.0800563105.

Wang, C. Y., N. Tani-Ishii, and P. Stashenko. 1997. "Bone-Resorptive Cytokine Gene Expression in Periapical Lesions in the Rat." Oral Microbiology and Immunology 12 (2): 65-71. https://doi.org/10.1111/j.1399-302X.1997.tb00619.x.

Wang, Piwen, Susanne M. Henning, and David Heber. 2010. "Limitations of MTT and MTS-Based Assays for Measurement of Antiproliferative Activity of Green Tea Polyphenols.” PLoS ONE 5 (4). https://doi.org/10.1371/journal.pone.0010202.

Weber, Karl T., Yao Sun, Suresh C. Tyagi, and Jack P.M. Cleutjens. 1994. "Collagen Network of the Myocardium: Function, Structural Remodeling and Regulatory Mechanisms." Journal of Molecular and Cellular Cardiology. https://doi.org/10.1006/jmcc.1994.1036.

Weterings, Eric, and Dik C. Van Gent. 2004. "The Mechanism of Non-Homologous End-Joining: A Synopsis of Synapsis.” DNA Repair. Elsevier. https://doi.org/10.1016/j.dnarep.2004.06.003. 
Wobbe, C. R., L. Weissbach, J. A. Borowiec, F. B. Dean, Y. Murakami, P. Bullock, and J. Hurwitz. 1987. "Replication of Simian Virus 40 Origin-Containing DNA in Vitro with Purified Proteins." Proceedings of the National Academy of Sciences of the United States of America. https://doi.org/10.1073/pnas.84.7.1834.

Wold, Marc S. 1997. "REPLICATION PROTEIN A:A Heterotrimeric, Single-Stranded DNA-Binding Protein Required for Eukaryotic DNA Metabolism.” Annual Review of Biochemistry 66 (1): 61-92. https://doi.org/10.1146/annurev.biochem.66.1.61.

Xu, Wei, Julie L. Lukkarila, Sara R. da Silva, Stacey-Lynn Paiva, Patrick T. Gunning, and Aaron D. Schimmer. 2013. "Targeting the Ubiquitin E1 as a Novel AntiCancer Strategy." Current Pharmaceutical Design 19 (18): 3201-9. https://doi.org/10.2174/1381612811319180004.

Yamanokuchi, Rumi, Kumiko Imada, Mitsue Miyazaki, Hikaru Kato, Tadashi Watanabe, Masahiro Fujimuro, Yasushi Saeki, et al. 2012. "Hyrtioreticulins A-E, Indole Alkaloids Inhibiting the Ubiquitin-Activating Enzyme, from the Marine Sponge Hyrtios Reticulatus.” Bioorganic and Medicinal Chemistry 20 (14): $4437-$ 42. https://doi.org/10.1016/j.bmc.2012.05.044.

Yang, G.-Y. 2000. "Effect of Black and Green Tea Polyphenols on C-Jun Phosphorylation and $\mathrm{H} 2 \mathrm{O} 2$ Production in Transformed and Non-Transformed Human Bronchial Cell Lines: Possible Mechanisms of Cell Growth Inhibition and Apoptosis Induction." Carcinogenesis 21 (11): 2035-39. https://doi.org/10.1093/carcin/21.11.2035.

Yang, Yili, Jirouta Kitagaki, Ren Ming Dai, Che Tsai Yien, Kevin L. Lorick, Robert L. Ludwig, Shervon A. Pierre, et al. 2007. "Inhibitors of Ubiquitin-Activating 
Enzyme (E1), a New Class of Potential Cancer Therapeutics.” Cancer Research 67 (19): 9472-81. https://doi.org/10.1158/0008-5472.CAN-07-0568.

Yasuda, Yoichi, Masahito Shimizu, Hiroyasu Sakai, Junpei Iwasa, Masaya Kubota, Seiji Adachi, Yosuke Osawa, Hisashi Tsurumi, Yukihiko Hara, and Hisataka Moriwaki. 2009. “(-)-Epigallocatechin Gallate Prevents Carbon Tetrachloride-Induced Rat Hepatic Fibrosis by Inhibiting the Expression of the PDGFR $\beta$ and IGF-1R.” Chemico-Biological Interactions 182 (2-3): 159-64. https://doi.org/10.1016/j.cbi.2009.07.015.

Zaveri, Nurulain T. 2006. “Green Tea and Its Polyphenolic Catechins: Medicinal Uses in Cancer and Noncancer Applications." In Life Sciences. https://doi.org/10.1016/j.lfs.2005.12.006.

Zhang, Ji Hu, Thomas D.Y. Chung, and Kevin R. Oldenburg. 1999. “A Simple Statistical Parameter for Use in Evaluation and Validation of High Throughput Screening Assays." Journal of Biomolecular Screening. https://doi.org/10.1177/108705719900400206.

Zhang, Jianglin, Zhou Lei, Zunnan Huang, Xu Zhang, Youyou Zhou, Zhongling Luo, Weiqi Zeng, Juan Su, Cong Peng, and Xiang Chen. 2016. "Epigallocatechin-3Gallate(EGCG) Suppresses Melanoma Cell Growth and Metastasis by Targeting TRAF6 Activity." Oncotarget 7 (48): 79557-71. https://doi.org/10.18632/oncotarget.12836.

Zhao, Linlin, and M. Todd Washington. 2017. "Translesion Synthesis: Insights into the Selection and Switching of DNA Polymerases." Genes. MDPI AG. https://doi.org/10.3390/genes8010024. 
Zhen, Mao Chuan, Xiao Hui Huang, Qian Wang, Kai Sun, Yun Jian Liu, Wen Li, Long Juan Zhang, Liang Qi Cao, and Xi Ling Chen. 2006. “Green Tea Polyphenol Epigallocatechin-3-Gallate Suppresses Rat Hepatic Stellate Cell Invasion by Inhibition of MMP-2 Expression and Its Activation.” Acta Pharmacologica Sinica 27 (12): 1600-1607. https://doi.org/10.1111/j.1745-7254.2006.00439.x.

Zhen, Mao chuan, Qian Wang, Xiao hui Huang, Liang qi Cao, Xi ling Chen, Kai Sun, Yun jian Liu, Wen Li, and Long juan Zhang. 2007. "Green Tea Polyphenol Epigallocatechin-3-Gallate Inhibits Oxidative Damage and Preventive Effects on Carbon Tetrachloride-Induced Hepatic Fibrosis.” Journal of Nutritional Biochemistry 18 (12): 795-805. https://doi.org/10.1016/j.jnutbio.2006.12.016. 


\section{Summary}

The DNA is continuously exposed at different stages of the cell cycle to various factors that work as a DNA damage agent and causes DNA damage. There are endogenous as well as exogenous factors such as reactive oxygen species, UV radiations, nitrogen mustard, formaldehyde, etc. that insults the DNA in various forms. The DNA damage triggers specialized DNA damage repair mechanisms. In some cases, classical DNA repair mechanisms are unable to repair the lesion and if the DNA damage left unrepaired, it stalls the progressing replication fork in S-phase of the cell cycle. At stalled replication fork, PCNA undergoes monoubiquitination at K164 residues with the help of ubiquitinactivating enzyme UBA1 (E1), ubiquitin-conjugating enzyme Rad6 (E2) and Ubiquitin ligase $\operatorname{Rad} 18$ (E3). The monoubiquitination of PCNA works as a molecular switch that recruits special class of polymerases so-called translesion synthesis (TLS) polymerases. TLS polymerases carry out likely error-prone replication, which can lead to mutagenesis and carcinogenesis. This kind of repair, which is error-prone and involves TLS polymerases, known as Translesion DNA synthesis.

We have developed a high throughput assay to screen for modulators of PCNA ubiquitination a key step involved in TLS synthesis, error-prone DNA damage repair pathway. We further refined the reconstituted systems for the more sensitive Alpha technology. We sought to reduce the concentrations of the components in the reactions and optimize the subsequent detection step of the assays like Ubal ubiquitin thioester, Rad6 ubiquitin thioester, Rad6-Rad18 interaction assay and Rad18 auto-ubiquitination assay.

We have discovered a green tea molecule EGCG, a potent inhibitor of Uba1 Ubiquitin thioester formation thus inhibiting ubiquitination. We have tested EGCG in HEK 293 cell 
and we have observed it has anti-proliferative activity. NMR studies have also shown which proves the direct binding of EGCG with Uba1. The EGCG and Uba1 interactions are reversible which has been studied by carrying out centrifugal washout experiments. Overexpression of Uba1 in HEK 293 cells protects them from inhibitory effects of EGCG. Furthermore, we have found out that EGCG inhibits global ubiquitination in cells.

EGCG and related molecules have been tested for PCNA ubiquitination, Uba1 ubiquitin thioester, effects on the viability of HEK 293 cells. The catechin galloyl ester EGCG and ECG tested were active in all the assays. The unesterified catechins tested, (-)epigallocatechin (EGC) displayed weak activity in the PCNA ubiquitination and Uba1 ubiquitin thioester formation assays, while (-)-epicatechin (EC) and (+)-catechin (Cat) were inactive in both of these assays. Unlike EC and Cat, EGC also has measurable cytostatic/cytotoxic activity. However, EGC's negative effect on cell survival was not affected by Uba1 or ubiquitin overexpression. Free gallic acid (GA) and $n$-propyl gallate (PG), a short straight-chain alkyl galloyl ester, were inactive in the PCNA ubiquitination and Uba1 ubiquitin thioester formation assays but had little effects on cell viability. The inhibitory activity was observed, was not mitigated with Ubal or ubiquitin overexpression. Longer linear alkyl galloyl esters-n-octyl gallate (OG) and $n$-dodecyl (lauryl) gallate (DG) — were active in all the assays and overexpression of Ubal or ubiquitin protected cells from their negative effects on cell survival. Myricetin (Myr) and (+)-dihydromyricetin (DM; also known as ampelopsin) were active against PCNA ubiquitination and Uba1 ubiquitin thioester formation but only had very weak activity against cell survival, although cells were protected from even that weak cytostatic/cytotoxic activity by overexpression of Ubal or ubiquitin. The alkyl gallates inhibited PCNA ubiquitination and Ubal ubiquitin thioester formation with a potency directly proportional to the length of their alkyl chains in the rank order: $\mathrm{DG}>\mathrm{OG} \gg \mathrm{PG}$ 
(the last one more-or-less inactive); Myr and DM also inhibited PCNA ubiquitination and Uba1 ubiquitin thioester formation in the order: Myr 》 DM. However, with Myr, unlike with EGCG, preincubation of not only Ubal alone but also ubiquitin alone prior to adding the other reaction components for thioester formation resulted in inhibition. Since the presence of a Michael acceptor functionality in Myr makes a mechanism involving a covalent reaction with the target, which often but not always is irreversible, we tested whether Myr irreversibly inhibits PCNA ubiquitination or not by determining if enzyme activity recovers after washing out of the compound through serial centrifugal filtration. Myr's inhibitory effects on PCNA ubiquitination, like EGCG's, were reversible. We found half-maximal inhibitory concentration $\left(\mathrm{IC}_{50}\right)$ values and structure-activity relationship trends for Uba1 inhibitors we previously reported as determined by the Alpha assay generally corresponding to other more traditional methods in terms of both inhibitions the overall PCNA ubiquitination cascade and Ubal specifically. Thus, the system works not only as a screening tool for this reaction sequence but also as a legitimate quantitative method for measuring ubiquitination and formation of thioester conjugates without further modification from its high-throughput format. 


\section{9. Összefoglaló}

A DNS a sejtciklus során folyamatosan károsító tényezőknek van kitéve. Ezek között a tényezők között találunk exogén és endogén ágenseket, mint például reaktív oxigén gyökök, UV sugárzás, nitrogén-mustár, formaldehid, stb., amelyek különféle módon rongálják a DNS-t. A DNS-károsodások a sejtekben olyan különböző mechanizmusokat aktiválnak, melyeknek az a szerepe, hogy kijavítsák a keletkezett hibákat, ezért ezeket együttesen DNS-hibajavító mechanizmusoknak nevezzük. Jelen dolgozatban elsősorban a posztreplikációs hibajavító mechanizmussal foglalkozunk, amelyik az elakadt replikációs villánál indul. Ennek első fázisában a PCNA poszttranszlációs módosításon esik át, ami lehet ubikvitinálás vagy SUMOiláció, melyek révén egyrészt egyéb fehérjéket aktivál, másrészt meghatározza, hogy mely útvonalon haladjon a DNS-hibajavítás mechanizmusa. A PCNA molekula az elakadt replikációs villánál az UBA1 ubikvitinaktiváló enzim, a Rad6 ubikvitin-konjugáz és a Rad18 ubikvitin-ligáz hatására a K164-es lizinjén monoubikvitinálódik. A monoubikvitinált PCNA a polimerázok egy speciális családját, az ún. TLS (transzléziós szintézis) polimerázokat toborozza a hibához. Ezek a polimerázok hibásan írják át a DNS-szálat, ami mutagenezishez és végső soron karcinogenezishez vezet. Azt a folyamatot, amely hibás DNS-átírást eredményez és a TLS polimerázok révén valósul meg, transzléziós DNS szintézisnek nevezzük.

Munkám során egy nagy áteresztőképességü szürő módszert fejlesztettem ki, amely képes azonosítani a PCNA ubikvitinálást befolyásoló molekulákat. Ezt követően tovább fejlesztettük a felállított rendszert a jóval érzékenyebb Alpha technológiához. Célunk a reakciókban használt komponensek koncentrációjának csökkentése és az azt követő kimutatási lépés optimalizálása volt, az Uba1-ubikvitin tioészter, a Rad6-ubikvitin tioészter, a Rad6-Rad18 interakciós, valamint a Rad18 autoubikvitilálási assay-k esetén. 
A tesztek során sikeresen azonosítottunk egy a zöld teában lévő vegyületet, az EGCG-t (epigallocatechin gallát), amely az Ubal-ubikvitin tioészter komplex kialakulásának potenciális inhibitora, és ezáltal a PCNA ubikvitinálás hatékony gátlója lehet. Ezt követően az EGCG molekulát in vitro teszteltük HEK293 sejtvonalban, ahol sejtosztódásgátló hatást mutatott. A sejtmagi mágneses rezonancia (NMR) tesztek igazolták az EGCG és az Ubal közvetlen kapcsolódását. Az EGCG és az Uba1 közötti kölcsönhatás reverzibilis, amit centrifugális-kimosási kísérletekkel vizsgáltunk. Az Uba1 fehérje HEK293 sejtekben történő túltermeltetése védelmet nyújtott az EGCG gátló hatásával szemben. Továbbá kimutattuk, hogy az EGCG globálisan gátolja az ubikvitinálást a sejtekben.

Vizsgáltuk az EGCG és rokon molekuláinak hatását a PCNA ubikvitinálásra, az Uba1ubikvitin tioészter komplexre és a HEK293 sejtek túlélésére. A kísérletekhez használt catechin galloyl észter EGCG és ECG (epigallocatechin) a tesztek során végig aktívnak mutatkozott. A nem-észterezett cathechin és (-)-ECG csupán alacsony aktivitást mutatott úgy a PCNA ubikvitinálás, mint az Ubal-ubikvitin tioészter formálás alkalmával, míg az (-)-epicatechin (EC) és a (+)-catechin (Cat) mindkét esetben inaktív maradt. Az EC-vel és a Cat-tal ellentétben az ECG-nek mérhető citosztatikus/citotoxikus hatása is volt. Az ECG negatív hatását a sejtek túlélésére nem befolyásolta az Ubal vagy az ubikvitin túltermeltetése. A szabad galluszsav (GA) és az n-propyl gallát (PG), egy rövid, egyenes láncú alkil-galloil-észter, szintén inaktív volt a PCNA ubikvitinálás és az Uba1-ubikvitin tioészter komplex formációs tesztek során, de a sejtek túlélését kis mértékben befolyásolták. Ezt a gátló hatást az Uba1 vagy az ubiquitin túlzott expressziója nem mérsékelte. A hosszabb egyenes láncú alkil galloil észterek, az n-octil gallát (OG) és az n-dodecil (lauril) gallát (DG), minden vizsgált tesztben aktívak voltak, és az Uba1 vagy az ubikvitin túltermelése védelmet nyújtott a sejteknek a túlélésre gyakorolt negatív 
hatástól. A miricetin (Myr) és a (+)-dihidromiricetin (DM; vagy ampelopsin) a PCNA ubikvitinálás és Uba1-ubikvitin tioészter komplex formációs tesztek során aktivitást mutattak, de a sejtek túlélésére csak gyenge hatást gyakoroltak, az Ubal vagy az ubikvitin túltermelése pedig ezzel a gyenge citosztatikus/citotoxikus hatással szemben is védelmet biztosított. Az alkil-gallátok a bennük található alkil lánc hosszával arányos mértékben gátolták a PCNA ubikvitinálást és az Uba1-ubikvitin tioészter komplex képződést a következők szerint: DG > OG 》 PG (utóbbi alig mutatva már mérhető aktivitást). A Myr és a DM szintén gátolta a PCNA ubikvitinálást és az Ubal-ubikvitin tioészter komplex képződést, ebben a sorrendben: Myr 》 DM. Míg az EGCG esetében csak az Uba1-gyel történő elöinkubálás vezetett gátláshoz a tioészter komplex formálódási teszt során, addig a Myr esetében ez a gátlás az ubikvitinnel történt előinkubálás esetén is megfigyelhető volt. Azt is megvizsgáltuk, hogy a Myr irreverzibilisen gátolja-e a PCNA ubikvitinálást, mérve az enzimaktivitás helyreállását azt követően, hogy a ligandumot kimostuk a komplexből sorozatos centrifugálásos-szüréses fázisok segítségével. A Myr az EGCGhez hasonlóan reverzibilisen gátolja a PCNA ubikvitinálódást, ami azzal magyarázható, hogy a Myr-ben található Michael-féle akceptor funkciós csoport nem minden esetben eredményez kovalens reakciót a targettel.

Az Uba1-gátlók esetében tapasztalt fél maximális gátlókoncentráció (IC50) értékek és a szerkezet-aktivitás összefüggési tendenciák Alfa-teszttel meghatározva hasonlóak, mint amelyeket korábban közöltünk hagyományosabb módszerrel, az általános PCNA ubikvitinálási kaszkádban és az Uba1 által érintett folyamatban egyaránt. Így a rendszer nemcsak ennek a kölcsönhatásnak a szürőeszközeként müködik, hanem legitim kvantitatív módszerként széleskörüen is alkalmazható az ubikvitináció és a tioészterkonjugátumok képződésének mérésére, anélkül, hogy tovább kellene módosítani nagy áteresztőképességü jellegét. 


\section{List of Publications}

MTMT number: 10069362

1. Mandatory peer-reviewed international publications for the fulfillment of the doctoral process and on which this thesis is based:

- *Fenteany, G., *Gaur, P., Hegedűs, L., Dudás, K., Kiss, E., Wéber, E., Hackler, L., Martinek, T., Puskás, L.G., and Haracska, L (2019). Multilevel structureactivity profiling reveals multiple green tea compound families that each modulate ubiquitin-activating enzyme and ubiquitination by a distinct mechanism. Scientific Reports, 9(1). https://doi.org/10.1038/s41598-019-48888-6 (*shared first authors) IF: 4.525

- *Fenteany, G., *Gaur, P., Sharma, G., Pintér, L., Kiss, E., \& Haracska, L. (2020). Robust high-throughput assays to assess discrete steps in ubiquitination and related cascades. BMC Molecular and Cell Biology,21(1). https://doi.org/10.1186/s12860-020-00262-5 (*shared first authors) IF: 3.227

\section{Publications in refereed journals}

- *Fenteany, G., *Gaur, P., Hegedüs, L., Dudás, K., Kiss, E., Wéber, E., Hackler, L., Martinek, T., Puskás, L.G., and Haracska, L (2019). Multilevel structureactivity profiling reveals multiple green tea compound families that each modulate ubiquitin-activating enzyme and ubiquitination by a distinct mechanism. Scientific Reports, 9(1). https://doi.org/10.1038/s41598-019-48888-

6 (*shared first authors) IF: 4.525

- *Fenteany, G., *Gaur, P., Sharma, G., Pintér, L., Kiss, E., \& Haracska, L. (2020). Robust high-throughput assays to assess discrete steps in ubiquitination and 
related cascades. BMC Molecular and Cell Biology,21(1). https://doi.org/10.1186/s12860-020-00262-5 (*shared first authors) IF: 3.227

\section{Other scientific work}

- Talk entitled "Small molecule inhibitors of PCNA ubiquitination and post replication repair" at the 10th CEGSDM (Central European Genome Stability and DNA Repair Meeting) in Bratislava, Slovakia, $26^{\text {th }}-27^{\text {th }}$ September 2019

- Talk entitled "PCNA Orchestrates the DNA Damage Tolerance Pathway" at the Annual Conference of the Doctoral School of Biology and UNKP Conference (2018), Szeged, Hungary, $28^{\text {th }}-30^{\text {th }}$ May 2018

- Poster entitled "Targeting Translesion DNA Synthesis for Cancer Therapeutics" at the 9th CEGSDM (Central European Genome Stability and DNA Repair Meeting) in Warsaw, Poland, $13^{\text {th }}-14^{\text {th }}$ September 2018

- Poster entitled "Fighting Fatal Errors: Targeting Translesion DNA synthesis to Kill Cancer" at the GINOP conference held at the University of Debrecen, Debrecen, Hungary on $14^{\text {th }}-15^{\text {th }}$ June 2018

- Poster entitled "Using Artificial Amino Acid to study the interaction between Polymerase $\eta$ and PCNA" at the Central European Genome Stability Meeting Research Centre for Natural Sciences, Budapest, Hungary on $29^{\text {th }}-30^{\text {th }}$ September 2017

- Poster entitled "Artificial Amino Acid and its application in Protein-Protein interactions" at the Straub-days conference held at BRC, Szeged, Hungary on $24^{\text {th }}-25^{\text {th }}$ May 2017 
- Attended International conference on "Cellular and molecular mechanisms of disease processes" at the Department of Biotechnology, the University of Kashmir from $13^{\text {th }}-16$ th April 2014 


\section{Declaration}

I declare that the data used in the thesis written by Paras Gaur reflect the contribution of the doctoral candidate to the article: "*Fenteany, G., *Gaur, P., Hegedüs, L., Dudás, K., Kiss, E., Wéber, E., Hackler, L., Martinek, T., Puskás, L.G., and Haracska, L (2019). Multilevel structure-activity profiling reveals multiple green tea compound families that each modulate ubiquitin-activating enzyme and ubiquitination by a distinct mechanism. Scientific Reports, 9(1). https://doi.org/10.1038/s41598-01948888-6 (*shared first authors) IF: 4.525" and "*Fenteany, G., *Gaur, P., Sharma, G., Pintér, L., Kiss, E., \& Haracska, L. (2020). Robust high-throughput assays to assess discrete steps in ubiquitination and related cascades. BMC Molecular and Cell Biology, 21(1). https://doi.org/10.1186/s12860-020-00262-5 (*shared first authors)

\section{IF: 3.227"}

The results reported in the Ph.D. thesis and the publication were not used to acquire any $\mathrm{Ph} . \mathrm{D}$. degree previously. I further declare that the candidate has made a significant contribution to the creation of the above mentioned publication.

Szeged, 04 June 2020

Lajos Haracska Ph.D., D.Sc. 


\section{Co-authors Declaration}

I declare that the data used in the thesis written by Paras Gaur reflect the contribution of the doctoral candidate to the article: "*Fenteany, G., *Gaur, P., Hegedüs, L., Dudás, K., Kiss, E., Wéber, E., Hackler, L., Martinek, T., Puskás, L.G., and Haracska, L (2019). Multilevel structure-activity profiling reveals multiple green tea compound families that each modulate ubiquitin-activating enzyme and ubiquitination by a distinct mechanism. Scientific Reports, 9(1). https://doi.org/10.1038/s41598-01948888-6 (*shared first authors) IF: 4.525” and "*Fenteany, G., *Gaur, P., Sharma, G., Pintér, L., Kiss, E., \& Haracska, L. (2020). Robust high-throughput assays to assess discrete steps in ubiquitination and related cascades. BMC Molecular and Cell Biology, 21(1). https://doi.org/10.1186/s12860-020-00262-5 (*shared first authors) IF: 3.227"

The results reported in the Ph.D. thesis and the publication were not used to acquire any Ph.D. degree previously. I further declare that the candidate has made a significant contribution to the creation of the above mentioned publication.

Szeged, 04 June 2020

Gabriel Fenteany, Ph.D. 


\section{Appendix}

S1

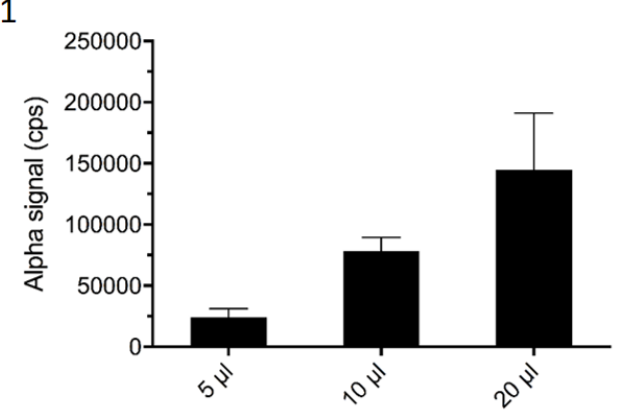

S2

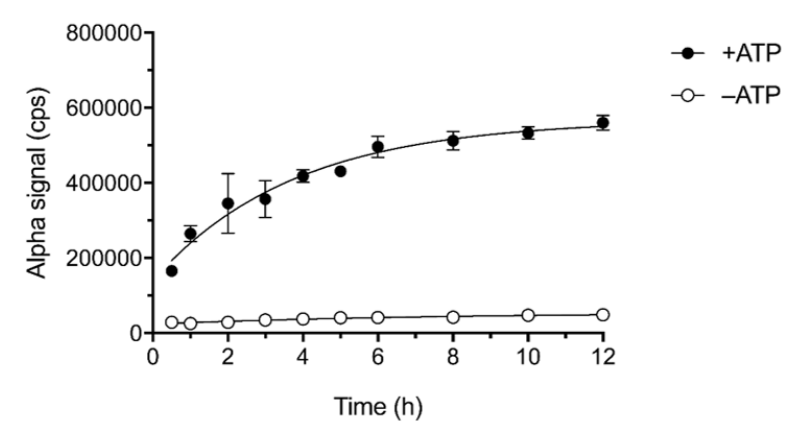

S3
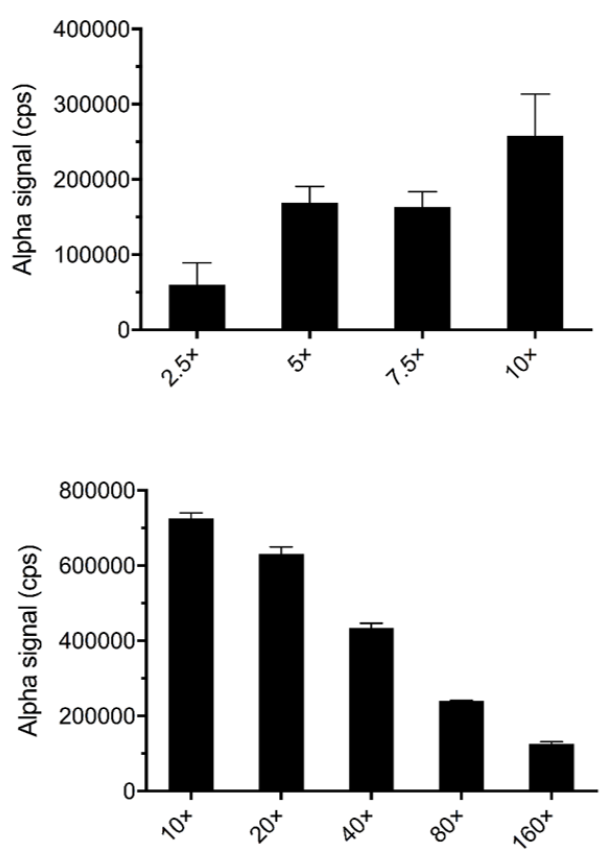

Figure S1. PCNA ubiquitination reaction volumes. The reaction with optimized conditions was performed in reaction volumes of $5 \mu 1,10 \mu \mathrm{l}$ and $20 \mu \mathrm{l}$, with incubation for $2 \mathrm{~h}$ at $25{ }^{\circ} \mathrm{C}$, followed by Alpha detection with the assay carried out otherwise as described in the Materials and Methods section. Figure S2. Donor and acceptor bead incubation times for the detection of ubiquitinated PCNA. Times of incubation with beads before Alpha detection were evaluated with donor and acceptor bead concentrations at $10 \mu \mathrm{g} / \mathrm{ml}$ each. Data represent mean and SD for 3 samples. Figure S3. Dilution factors for the detection of ubiquitinated PCNA. PCNA ubiquitination reactions were diluted to different degrees as indicated in Alpha buffer with donor and acceptor beads, followed by incubation and detection. Data represent mean and SD for $\geq 3$ samples. Top and bottom panels represent two separate experiments with different ranges of dilution. 
S4

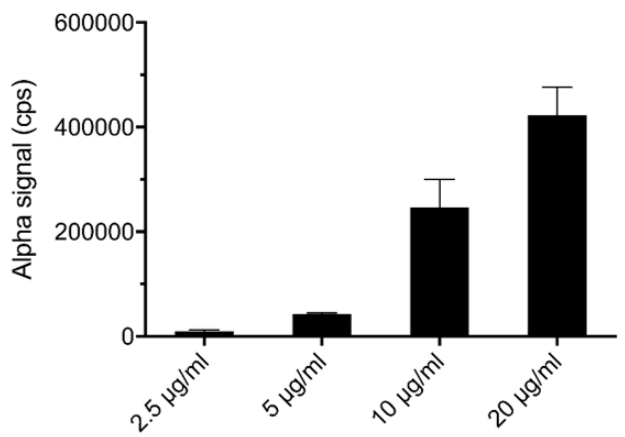

S6

S5
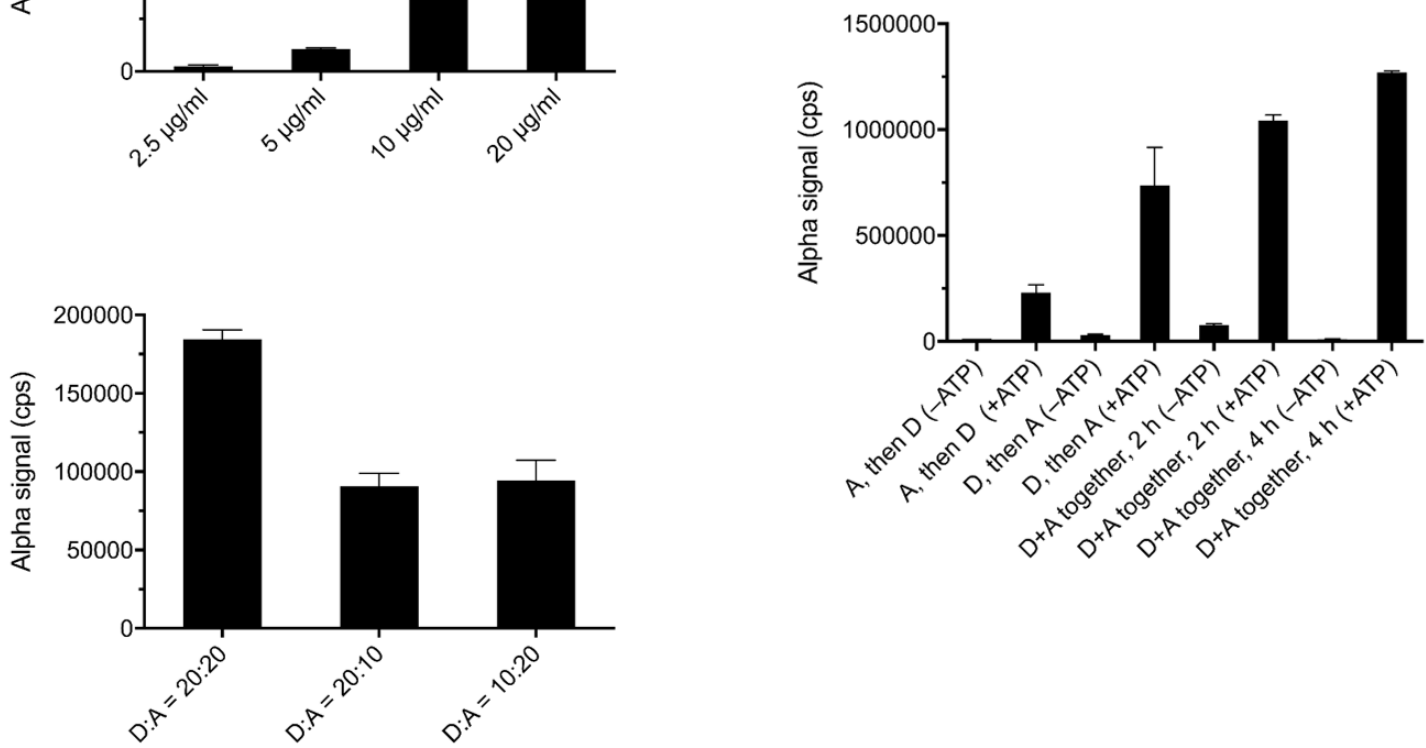

Figure S4. The donor and acceptor bead concentrations. The concentrations of donor and acceptor beads were varied, as indicated, followed by incubation and detection. Data represent mean and SD for 4 samples. Figure S5. The donor and acceptor bead ratios (values in $\mu \mathrm{g} / \mathrm{ml}$ ) were varied, followed by incubation and detection. Data represent mean and SD for 7-8 samples. D= donor beads; A = acceptor beads. Figure S6. Donor and acceptor bead order of addition for detection of ubiquitinated PCNA. The order of addition of Alpha donor and acceptor beads was examined, with incubation for $2 \mathrm{~h}$ with one and then further for $2 \mathrm{~h}$ after addition of the other (compared to simultaneous addition and incubation for $2 \mathrm{~h}$ or $4 \mathrm{~h}$ ), followed by detection. Data represent mean and SD for 3 samples. $\mathrm{D}=$ donor beads; $\mathrm{A}=$ acceptor beads. 
S7

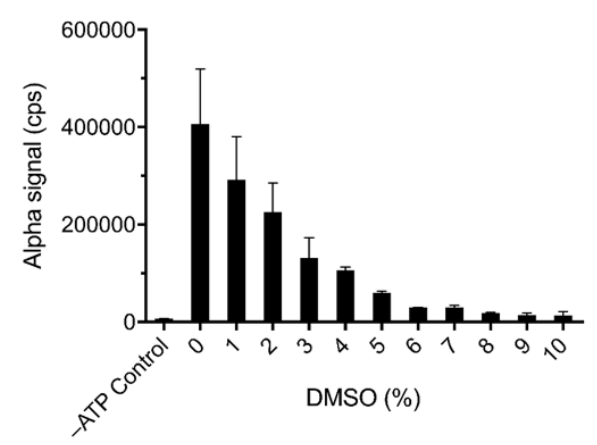

S8

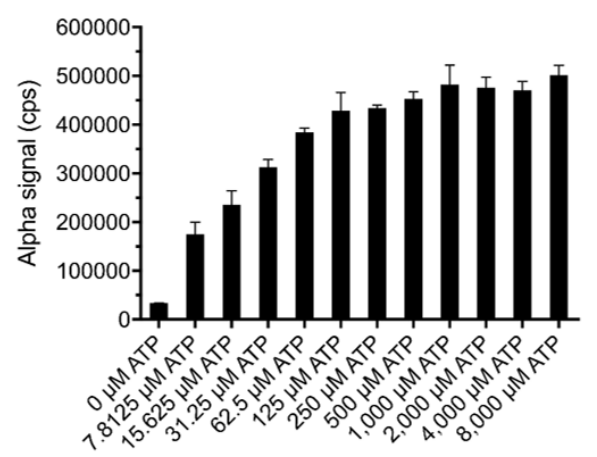

Figure S7 and S8. Variation of DMSO tolerance and ATP concentration in Alpha assay for PCNA ubiquitination. S7. Different concentrations of DMSO were added to the reactions, followed by incubation and detection. Data represent mean and SD for 3 samples. S8ATP concentrations for the PCNA ubiquitination cascade were varied, followed by incubation and detection. Data represent mean and SD for 3 samples.

Note: The PCNA ubiquitination conditions for Figures S1, S2, S3, S4, S5, S6, S7 and S8 were based on Figures 8 and 9 in the Results and Conclusion section.

Supplementary Table 1.

\begin{tabular}{|l|l|l|}
\hline Compounds & Company & Catalog no. \\
\hline (-)-Epigallocatechin-3-gallate & $\begin{array}{l}\text { Avicor and Selleck } \\
\text { Chemicals }\end{array}$ & $\begin{array}{l}\text { Selleck Chemicals } \\
\text { Cat\#S2250 }\end{array}$ \\
\hline (-)-Epicatechin-3-gallate & Selleck Chemicals & Cat\#S3925 \\
\hline (-)-Epigallocatechin & Selleck Chemicals & Cat\#S3922 \\
\hline (-)-Epicatechin & Selleck Chemicals & Cat\#S4723 \\
\hline (+)-Catechin & Selleck Chemicals & Cat\#S4722 \\
\hline Gallic acid & Selleck Chemicals & Cat\#S4603 \\
\hline$n$-Propyl gallate & Avicor & N/A \\
\hline$n$-Octyl gallate & Avicor & N/A \\
\hline$n$-Dodecyl gallate & Avicor & N/A \\
\hline Myricetin & $\begin{array}{l}\text { Avicor and Adooq } \\
\text { Bioscience }\end{array}$ & $\begin{array}{l}\text { Adooq Bioscience } \\
\text { Cat\#A10615 }\end{array}$ \\
\hline (+)-Dihydromyricetin & $\begin{array}{l}\text { Avicor and Adooq } \\
\text { Bioscience }\end{array}$ & $\begin{array}{l}\text { Adooq Bioscience } \\
\text { Cat\#A1025 }\end{array}$ \\
\hline
\end{tabular}

\section{Supplementary Table 2.}

Half-maximal inhibitory concentration ( IC $_{50}$ ) values for compounds against PCNA ubiquitination and Uba1 ubiquitin thioester formation and effects on the viability of normal, Uba1-overexpressing and ubiquitin-overexpressing cells. All $\mathrm{IC}_{50}$ values, standard errors and 95\% confidence intervals listed were calculated by nonlinear regression with GraphPad Prism software. The effects of compounds on cell survival in Uba1 and ubiquitin-overexpressing cells relative to empty vector-transfected control cells 
are also shown. $\mathrm{SE}=$ standard error; $\mathrm{CI}=95 \%$ confidence interval; $n=$ number of independent experiments; $\mathrm{N} / \mathrm{A}=$ not applicable.

\begin{tabular}{|c|c|c|c|c|c|}
\hline $\begin{array}{l}\text { Compoun } \\
\text { d }\end{array}$ & $\begin{array}{l}\text { IC50 for } \\
\text { inhibition of } \\
\text { PCNA } \\
\text { ubiquitinatio } \\
n\end{array}$ & $\begin{array}{l}\text { IC } 50 \text { for } \\
\text { inhibition of } \\
\text { Uba1 ubiquiti } \\
\text { n thioester } \\
\text { formation }\end{array}$ & $\begin{array}{l}\text { IC50 for } \\
\text { inhibitio } \\
\text { n of cell } \\
\text { survival }\end{array}$ & $\begin{array}{l}\text { Effect of Uba1 } \\
\text { overexpressio } \\
\text { n on cell } \\
\text { survival }\end{array}$ & $\begin{array}{l}\text { Effect of } \\
\text { ubiquitin } \\
\text { overexpressio } \\
\text { n on cell } \\
\text { survival }\end{array}$ \\
\hline EGCG & $\begin{array}{l}0.2280 \mu \mathrm{M} \\
(\mathrm{SE}= \\
0.03419 ; \mathrm{CI}: \\
0.1714- \\
0.3192 ; n=7)\end{array}$ & $\begin{array}{l}1.632 \mu \mathrm{M}(\mathrm{SE}= \\
0.4580 ; \mathrm{CI}: \\
0.8348-3.451 ; n \\
=4)\end{array}$ & $\begin{array}{l}220.2 \mu \mathrm{M} \\
(\mathrm{SE}= \\
18.90 ; \mathrm{CI}: \\
187.4- \\
263.5 ; n= \\
6)\end{array}$ & Protects & Protects \\
\hline ECG & $\begin{array}{l}0.5369 \mu \mathrm{M} \\
(\mathrm{SE}= \\
0.09460 ; \mathrm{CI}: \\
0.3750- \\
0.8431 ; n=4)\end{array}$ & $\begin{array}{l}4.223 \mu \mathrm{M}(\mathrm{SE}= \\
2.161 ; \mathrm{CI}: \\
1.263-13.77 ; n \\
=6)\end{array}$ & $\begin{array}{l}261.7 \mu \mathrm{M} \\
(\mathrm{SE}= \\
33.88 ; \mathrm{CI}: \\
206.2- \\
353.4 ; n= \\
6)\end{array}$ & Protects & Protects \\
\hline EGC & $\begin{array}{l}43.28 \mu \mathrm{M}(\mathrm{SE} \\
=22.81 ; \mathrm{CI}: \\
16.08-129.0 \\
n=4)\end{array}$ & $\begin{array}{l}7.584 \mu \mathrm{M}(\mathrm{SE}= \\
3.869 ; \mathrm{CI}: \\
2.927-20.67 ; n \\
=7)\end{array}$ & $\begin{array}{l}175.7 \mu \mathrm{M} \\
(\mathrm{SE}= \\
18.05 ; \mathrm{CI}: \\
144.0- \\
218.5 ; n= \\
4)\end{array}$ & $\begin{array}{l}\text { Does not } \\
\text { protect }\end{array}$ & $\begin{array}{l}\text { Does not } \\
\text { protect }\end{array}$ \\
\hline $\mathrm{EC}$ & $\begin{array}{l}>500 \mu \mathrm{M}(n= \\
3)\end{array}$ & $\begin{array}{l}>500 \mu \mathrm{M}(n= \\
4)\end{array}$ & $\begin{array}{l}>500 \mu \mathrm{M} \\
(n=4)\end{array}$ & N/A & N/A \\
\hline Cat & $\begin{array}{l}>500 \mu \mathrm{M}(n= \\
3)\end{array}$ & $\begin{array}{l}>500 \mu \mathrm{M}(n= \\
4)\end{array}$ & $\begin{array}{l}>500 \mu \mathrm{M} \\
(n=4)\end{array}$ & $\mathrm{N} / \mathrm{A}$ & $\mathrm{N} / \mathrm{A}$ \\
\hline GA & $\begin{array}{l}>500 \mu \mathrm{M}(n= \\
3)\end{array}$ & $\begin{array}{l}>500 \mu \mathrm{M}(n= \\
4)\end{array}$ & $\begin{array}{l}240.7 \mu \mathrm{M} \\
(\mathrm{SE}= \\
18.12 ; \mathrm{CI}: \\
206.6- \\
280.3: n= \\
4)\end{array}$ & $\begin{array}{l}\text { Does not } \\
\text { protect }\end{array}$ & $\begin{array}{l}\text { Does not } \\
\text { protect }\end{array}$ \\
\hline PG & $\begin{array}{l}>500 \mu \mathrm{M}(n= \\
3)\end{array}$ & $\begin{array}{l}>500 \mu \mathrm{M}(n= \\
4)\end{array}$ & $\begin{array}{l}176.3 \mu \mathrm{M} \\
(\mathrm{SE}= \\
23.55 ; \mathrm{CI}: \\
135.8- \\
240.4 ; n= \\
4)\end{array}$ & $\begin{array}{l}\text { Does not } \\
\text { protect }\end{array}$ & $\begin{array}{l}\text { Does not } \\
\text { protect }\end{array}$ \\
\hline OG & $\begin{array}{l}10.32 \mu \mathrm{M}(\mathrm{SE} \\
=6.406 ; \mathrm{CI}: \\
3.182-40.09 ; \\
n=4)\end{array}$ & $\begin{array}{l}80.60 \mu \mathrm{M}(\mathrm{SE}= \\
33.90 ; \mathrm{CI}: \\
34.81-405.1 ; n \\
=4)\end{array}$ & $\begin{array}{l}38.70 \mu \mathrm{M} \\
(\mathrm{SE}= \\
3.106 ; \mathrm{CI}:\end{array}$ & Protects & Protects \\
\hline
\end{tabular}




\begin{tabular}{|c|c|c|c|c|c|}
\hline & & & $\begin{array}{l}32.72- \\
45.46 \\
n=4)\end{array}$ & & \\
\hline DG & $\begin{array}{l}1.633 \mu \mathrm{M}(\mathrm{SE} \\
=0.3117 ; \mathrm{CI}: \\
1.048-2.670 \\
n=5)\end{array}$ & $\begin{array}{l}35.00 \mu \mathrm{M}(\mathrm{SE}= \\
25.11 ; \mathrm{CI}: \\
6.288-533.1 ; n \\
=4)\end{array}$ & $\begin{array}{l}33.46 \mu \mathrm{M} \\
(\mathrm{SE}= \\
3.247 ; \mathrm{CI}: \\
27.15- \\
40.83 ; n= \\
4)\end{array}$ & $\begin{array}{l}\text { Does not } \\
\text { protect }\end{array}$ & Protects \\
\hline Myr & $\begin{array}{l}1.213 \mu \mathrm{M}(\mathrm{SE} \\
=0.2083 \text {; CI: } \\
0.8755-4.201 ; \\
n=5)\end{array}$ & $\begin{array}{l}0.7207 \mu \mathrm{M}(\mathrm{SE} \\
=0.4970 ; \mathrm{CI}: \\
0.1766-2.680 ; n \\
=5)\end{array}$ & $\begin{array}{l}>500 \mu \mathrm{M} \\
(n=6)\end{array}$ & Protects & Protects \\
\hline DM & $\begin{array}{l}66.43 \mu \mathrm{M}(\mathrm{SE} \\
=38.92 ; \mathrm{CI}: \\
27.21-180.9 ; \\
n=3)\end{array}$ & $\begin{array}{l}14.27 \mu \mathrm{M}(\mathrm{SE}= \\
3.140 ; \mathrm{CI}: \\
5.927-22.18 ; n \\
=3)\end{array}$ & $\begin{array}{l}>500 \mu \mathrm{M} \\
(n=6)\end{array}$ & $\begin{array}{l}\text { Does not } \\
\text { protect }\end{array}$ & Protects \\
\hline
\end{tabular}

\section{Supplementary Table 3.}

Half-maximal inhibitory concentration (IC50) values for compounds against PCNA ubiquitination and Uba1 ubiquitin thioester by Alpha assay compared to other methods. All $\mathrm{IC}_{50}$, standard error (SE) and 95\% confidence interval (CI) values listed were calculated by nonlinear regression with GraphPad Prism 8 software; $n=$ number of replicates; Ind. = indeterminate.

\begin{tabular}{|c|c|c|c|c|}
\hline Compound & $\begin{array}{l}\text { IC50 for } \\
\text { inhibition of } \\
\text { PCNA } \\
\text { ubiquitination } \\
\text { (Alpha) }\end{array}$ & $\begin{array}{l}\text { IC50 for } \\
\text { inhibition of } \\
\text { PCNA } \\
\text { ubiquitination } \\
\text { (Western blot) }\end{array}$ & $\begin{array}{l}\text { IC50 for } \\
\text { inhibition of } \\
\text { Uba1 Ub } \\
\text { thioester } \\
\text { formation } \\
\text { (Alpha) }\end{array}$ & $\begin{array}{l}\text { IC50 for } \\
\text { inhibition of } \\
\text { Uba1 Ub } \\
\text { thioester } \\
\text { formation (gel- } \\
\text { based) }\end{array}$ \\
\hline EGCG & $\begin{array}{l}0.05656 \mu \mathrm{M}(\mathrm{SE} \\
=0.009536 ; \mathrm{CI}: \\
0.04086- \\
0.07757 ; n=5)\end{array}$ & $\begin{array}{l}0.2280 \mu \mathrm{M}(\mathrm{SE} \\
=0.03419 ; \mathrm{CI}: \\
0.1714-0.3192 ; \\
n=7)\end{array}$ & $\begin{array}{l}0.4878 \mu \mathrm{M}(\mathrm{SE} \\
=0.1446 ; \mathrm{CI}: \\
0.2586- \\
0.9488 ; n=3)\end{array}$ & $\begin{array}{l}1.632 \mu \mathrm{M}(\mathrm{SE}= \\
0.4580 ; \mathrm{CI}: \\
0.8348-3.451 ; n \\
=4)\end{array}$ \\
\hline
\end{tabular}




\begin{tabular}{|c|c|c|c|c|}
\hline ECG & $\begin{array}{l}0.09879 \mu \mathrm{M}(\mathrm{SE} \\
=0.04420 ; \mathrm{CI}: \\
0.03177-0.2749 \\
n=4)\end{array}$ & $\begin{array}{l}0.5369 \mu \mathrm{M}(\mathrm{SE} \\
=0.09460 ; \mathrm{CI}: \\
0.3750-0.8431 ; \\
n=4)\end{array}$ & $\begin{array}{l}0.6706 \mu \mathrm{M}(\mathrm{SE} \\
=0.3549 ; \mathrm{CI}: \\
\text { Ind.-0.9978; } n \\
=3)\end{array}$ & $\begin{array}{l}4.223 \mu \mathrm{M}(\mathrm{SE}= \\
2.161 ; \mathrm{CI}: 1.263- \\
13.77 ; n=6)\end{array}$ \\
\hline EGC & $\begin{array}{l}6.620 \mu \mathrm{M}(\mathrm{SE}= \\
3.228 ; \mathrm{CI}: \\
2.916-16.52 ; n= \\
3)\end{array}$ & $\begin{array}{l}43.28 \mu \mathrm{M}(\mathrm{SE} \\
=22.81 ; \mathrm{CI}: \\
16.08-129.0 ; n \\
=4)\end{array}$ & $\begin{array}{l}5.960 \mu \mathrm{M}(\mathrm{SE} \\
=17.28 ; \mathrm{CI}: \\
0.1009-\text { Ind.; } n \\
=3)\end{array}$ & $\begin{array}{l}7.584 \mu \mathrm{M}(\mathrm{SE}= \\
3.869 ; \mathrm{CI}: 2.927- \\
20.67 ; n=7)\end{array}$ \\
\hline $\mathrm{EC}$ & $>500 \mu \mathrm{M}(n=6)$ & $\begin{array}{l}>500 \mu \mathrm{M}(n= \\
3)\end{array}$ & $\begin{array}{l}>500 \mu \mathrm{M}(n= \\
3)\end{array}$ & $>500 \mu \mathrm{M}(n=4)$ \\
\hline Cat & $\begin{array}{l}\text { ca. } 500 \mu \mathrm{M}(n= \\
6)\end{array}$ & $\begin{array}{l}>500 \mu \mathrm{M}(n= \\
3)\end{array}$ & $\begin{array}{l}>500 \mu \mathrm{M}(n= \\
3)\end{array}$ & $>500 \mu \mathrm{M}(n=4)$ \\
\hline GA & $>500 \mu \mathrm{M}(n=6)$ & $\begin{array}{l}>500 \mu \mathrm{M}(n= \\
3)\end{array}$ & $\begin{array}{l}\text { ca. } 500 \mu \mathrm{M}(n \\
=3)\end{array}$ & $>500 \mu \mathrm{M}(n=4)$ \\
\hline PG & $>500 \mu \mathrm{M}(n=4)$ & $\begin{array}{l}>500 \mu \mathrm{M}(n= \\
3)\end{array}$ & $\begin{array}{l}>500 \mu \mathrm{M}(n= \\
3)\end{array}$ & $>500 \mu \mathrm{M}(n=4)$ \\
\hline $\mathrm{OG}$ & $\begin{array}{l}3.083 \mu \mathrm{M}(\mathrm{SE}= \\
0.6111 ; \mathrm{CI}: \\
2.589-6.353 ; n= \\
3)\end{array}$ & $\begin{array}{l}10.32 \mu \mathrm{M}(\mathrm{SE} \\
=6.406 ; \mathrm{CI}: \\
3.182-40.09 ; n \\
=4)\end{array}$ & $\begin{array}{l}13.36 \mu \mathrm{M}(\mathrm{SE} \\
=6.018 ; \mathrm{CI}: \\
5.341-38.48 ; n \\
=3)\end{array}$ & $\begin{array}{l}80.60 \mu \mathrm{M}(\mathrm{SE}= \\
33.90 ; \mathrm{CI}: 34.81- \\
405.1 ; n=4)\end{array}$ \\
\hline $\mathrm{DG}$ & $\begin{array}{l}3.727 \mu \mathrm{M}(\mathrm{SE}= \\
0.5664 ; \mathrm{CI}: \\
2.833-4.557 ; n= \\
3)\end{array}$ & $\begin{array}{l}1.633 \mu \mathrm{M}(\mathrm{SE} \\
=0.3117 ; \mathrm{CI}: \\
1.048-2.670 ; n \\
=5)\end{array}$ & $\begin{array}{l}44.42 \mu \mathrm{M}(\mathrm{SE} \\
=22.42 ; \mathrm{CI}: \\
18.82-149.6 ; n \\
=3)\end{array}$ & $\begin{array}{l}35.00 \mu \mathrm{M}(\mathrm{SE}= \\
25.11 ; \mathrm{CI}: 6.288- \\
533.1 ; n=4)\end{array}$ \\
\hline Myr & $\begin{array}{l}0.7599 \mu \mathrm{M}(\mathrm{SE}= \\
0.3928 ; \mathrm{CI}: \\
0.3229-2.614 ; n \\
=3)\end{array}$ & $\begin{array}{l}1.213 \mu \mathrm{M}(\mathrm{SE} \\
=0.2083 ; \mathrm{CI}: \\
0.8755-4.201 ; \\
n=5)\end{array}$ & $\begin{array}{l}1.592 \mu \mathrm{M}(\mathrm{SE} \\
=0.7459 ; \mathrm{CI}: \\
0.7213-4.216 ; \\
n=3)\end{array}$ & $\begin{array}{l}0.7207 \mu \mathrm{M}(\mathrm{SE}= \\
0.4970 ; \mathrm{CI}: \\
0.1766-2.680 ; n \\
=5)\end{array}$ \\
\hline $\mathrm{DM}$ & $\begin{array}{l}28.68 \mu \mathrm{M}(\mathrm{SE}= \\
5.299 ; \mathrm{CI}: 19.68- \\
49.40 ; n=4)\end{array}$ & $\begin{array}{l}66.43 \mu \mathrm{M}(\mathrm{SE} \\
=38.92 ; \mathrm{CI}: \\
27.21-180.9 ; n \\
=3)\end{array}$ & $\begin{array}{l}29.62 \mu \mathrm{M}(\mathrm{SE} \\
=15.14 ; \mathrm{CI}: \\
8.656-125.1 ; n \\
=4)\end{array}$ & $\begin{array}{l}14.27 \mu \mathrm{M}(\mathrm{SE}= \\
3.140 ; \mathrm{CI}: 5.927- \\
22.18 ; n=3)\end{array}$ \\
\hline
\end{tabular}

